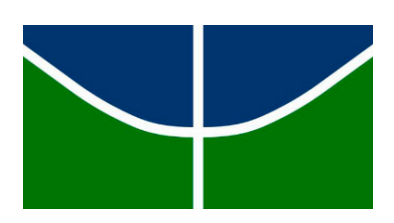

UNIVERSIDADE DE BRASÍLIA

FACULDADE DE EDUCAÇÃO FÍSICA

PROGRAMA DE PÓS-GRADUAÇÃO STRICTO-SENSU EM

EDUCAÇÃO FÍSICA

PERCEPÇÃO DE PROFESSORES DE EDUCAÇÃO FÍSICA SOBRE A PROMOÇÃO DA SAÚDE E O EIXO DE PRÁTICAS CORPORAIS E ATIVIDADES FÍSICAS NO PROGRAMA SAÚDE NA ESCOLA DO DISTRITO FEDERAL

IRANEIDE ETELVINA LOPES

BRASÍLIA 
PERCEPÇÃO DE PROFESSORES DE EDUCAÇÃO FÍSICA SOBRE A PROMOÇÃO DA SAÚDE E O EIXO DE PRÁTICAS CORPORAIS E ATIVIDADES FÍSICAS NO PROGRAMA SAÚDE NA ESCOLA DO DISTRITO FEDERAL

IRANEIDE ETELVINA LOPES

Dissertação apresentada à Faculdade de Educação Física da Universidade de Brasília como requisito parcial para obtenção do grau de Mestre em Educação Física.

ORIENTADORA: PROF. DRA. JÚLIA APARECIDA DEVIDÉ NOGUEIRA 


\section{PERCEPÇÃO DE PROFESSORES DE EDUCAÇÃO FÍSICA SOBRE A PROMOÇÃO DA SAÚDE E O EIXO DE PRÁTICAS CORPORAIS E ATIVIDADES FÍSICAS NO PROGRAMA SAÚDE NA ESCOLA DO DISTRITO FEDERAL}

Dissertação aprovada como requisito parcial para obtenção do título de Mestre em Educação Física pelo Programa de Pós-Graduação da Faculdade de Educação Física da Universidade de Brasília.

Banca examinadora

Prof. Dra. Júlia Aparecida Devidé Nogueira

(Orientadora - FEF/UnB)

Prof. Dra. Dais Gonçalves Rocha

(Examinadora Externa - FS/UnB)

Prof. Dra. Ingrid Dittrich Wiggers

(Examinadora Interna - FEF/UnB)

Prof. Dr. Jonatas Maia da Costa

(Suplente - FEF/UnB)

Brasília, 12 de agosto de 2016. 


\section{DEDICATÓRIA}

Dedico este trabalho a minha mãe Maria de Fátima (in memorian) e ao meu pai José Ananias por terem incentivado os primeiros passos dessa caminhada me matriculando na escola. 


\section{AGRADECIMENTOS}

Agradeço a Deus, por guiar meus passos, por ter me concedido força, saúde e coragem para desenvolver todas as atividades ao longo desses dois anos de mestrado, por suas bênçãos em minha vida e permitir mais um sonho realizado.

À professora Júlia Nogueira, pela oportunidade de cursar o mestrado e proporcionar novas possibilidades em um processo de reconstrução de minha formação. Pela paciência e delicadeza em diversos momentos de aprendizado (orientações e reuniões de estudos), sobretudo, os ensinamentos que pairavam em torno da ética em pesquisa. Pelos incentivos e apoio dados durante o percurso do mestrado. Enfim, por ter contribuído na elaboração do trabalho e em minha formação acadêmica e social. Gratidão sempre!

Agradeço à professora Dais Rocha, por contribuir com minha formação nesse período do mestrado compartilhando seus saberes de forma sensível e sublime, pela singela acolhida no estágio em docência, por toda oportunidade de aprendizado, pelas contribuições dadas na dissertação e por ser uma de minhas fontes de inspiração profissional. Gratidão!

À professora Ingrid Wiggers por sua disponibilidade, gentileza e valioso auxilio no percurso da pesquisa de mestrado e por contribuir com minha formação acadêmica.

Ao professor Jonatas da Costa que prontamente aceitou o convite para compor a banca de defesa da dissertação dando a oportunidade de aprendermos juntos.

À Josilda Ribeiro (minha amiga-irmã), e sua Família. Pelo carinho reportado a mim nesses últimos anos. Por me acolher com tanto amor, por estar ao meu lado nos momentos mais importantes da minha vida e me ajudar a ver além. Valeu por você existir, amiga.

Ao Pedro, pela paciência, amor e carinho de sempre. Pelo companheirismo e ajuda em todo período do mestrado. Por me tranquilizar nos momentos de aflições, entender minhas ausências e apoiar meus projetos e sonhos.

Ao meu pai José Ananias Lopes, por seu amor, carinho e ajuda em minha formação.

À Jessica Ingred, Iranilda Lopes e Jeysiane Nayara. Por ser fonte de motivação para que eu siga no caminho dos estudos, por todo amor e carinho reportado a mim. Pela ajuda, dada para que a moradia em Brasília fosse possível.

À Bruna Souza (Brunex!), Carolina Alzate e Christe Montijo pelos maravilhosos dias de convivência e pelo lindo laço de companheirismo e amizade. Entre abraços e partidas vivenciamos momentos de alegrias, descontração e aflição conjunta a cada defesa e testes. Deixo aqui a minha Gratidão por terem contribuído para que eu tivesse dias felizes em Brasília, vocês são totalmente demais!

À minha amiga Paula Silva (Paulinha!) por ter sido meu porto seguro em Brasília. Muito obrigada por toda força, companheirismo, pelos momentos de alegria, descontração e pelo o apreço reportado a mim.

À Ivana e Júlio por me acolher tão bem desde a época da seleção até o período inicial do curso em Brasília. Gratidão pelo apoio e consideração. 
Aos amigos e amigas que conheci nesses últimos dois anos morando em Brasília em especial: Ana Amélia, Denise Santos, Elaine Cristine, Rogério Almeida, Ariza Rodrigues (Viza) e Oswaldo Araújo (Vizo).

Aos colegas do Grupo de Estudos em Educação Física e Saúde Coletiva da Faculdade de Educação Física da Universidade de Brasília (Andrea Leite, Ciro Queiroz, Felipe Saul, Francilene Madeira, Hetty Lobo, Jorge Almeida e Rafael Barros), pelos dias de aprendizado e compartilhamento de saberes. Pela ajuda (contribuições) no percurso da pesquisa, pela solidariedade e apoio reportados a mim em vários momentos do curso e pela convivência harmoniosa. Gratidão!

A minhas amigas do grupo de trabalho: Fortaleça sua Saúde (Alexsandra Bandeira, Dayane Oliveira, Deuziane Brito, Soraya Anita) pelos intensos e prazerosos dias de trabalho e estudos, experiências compartilhadas, e ao querido Valter Filho pelos ensinamentos, incentivos, encorajamento para que eu concorresse ao mestrado e pela amizade duradoura de sempre. Gratidão!

À família Moreno (Evelyne, Celso e Dudu) pelos dias de risos mais singelos e de amor intenso. Pela amizade, consideração e compartilhamento de experiências.

A uma gama de amigas e amigos que torcem por mim e também me fazem uma pessoa melhor: Ana Mariano, Andréa Chagas, Angeliane Sales, Camila Camelo, Carla Emilly, Emerson Henrique, Francisco José, Geovani Martins, Gleidson Oliveira, Glênia Pinheiro, Jéssica Sousa, Josiane Santos, Joviniano Júnior, Klertianny Teixeira, Liana Gomes, Lucicleia Lourenço, Lucimara Benigno, Michele Costa, Moabe Domingos, Nara Rúbia, Natália Alencar, Rosilene Paiva, Rosiene Silva, Rogério Almeida, Sandrinha Zurk, Silda Santos, Vanessa Santos e Walquia Coelho. Quanto mais o tempo passa mais aumenta a graça em conviver com vocês.

Aos diversos professores (as) que perpassaram no meu caminho e plantaram sementes de sabedoria na minha formação. Eu deixo aqui a minha eterna gratidão.

Aos professores e funcionários do Programa de Pós-Graduação em Educação Física da Universidade de Brasília que em vários momentos ajudaram no andamento deste trabalho.

Agradeço profundamente à equipe do grupo gestor do PSE no DF: Wania Teles, Eliene Moreira e Bruno Araújo pelo o apoio, carinho e presteza apresentados à minha pessoa e pelas diversas contribuições no percurso da pesquisa. Gratidão!

Aos coordenadores e professores de Educação Física de cada uma das regionais que participaram e contribuíram para que a realização desta pesquisa fosse possível.

À Coordenação de Aperfeiçoamento de Pessoal de Nível Superior (CAPES), pelo financiamento da bolsa de mestrado.

Por fim, à Universidade de Brasília e a diretoria de Desenvolvimento Social pela assistência formidável e fundamental reportada a mim para que mais um passo em minha formação fosse possível. Gratidão! 
Mas é preciso ter força

É preciso ter raça

É preciso ter gana sempre

Quem traz no corpo a marca

Maria, Maria

Mistura a dor e a alegria

Mas é preciso ter manha

É preciso ter graça

É preciso ter sonho sempre

Quem traz na pele essa marca

Possui a estranha mania

De ter fé na vida

Milton Nascimento. 


\section{LISTA DE QUADROS, TABELAS E FIGURAS}

Página

Quadro 1. Descrição dos componentes e eixos de ações presentes na normativa nacional do Programa Saúde na Escola (BRASIL, 2007a). 30

Quadro 2. Etapas do estudo desenvolvido com professores de Educação Física que atuam em escolas que aderiam ao PSE na vigência 2014 e 2015. 38

Quadro 3. Panorama dos artigos científicos publicados entre 2007 e 2016 que se referem ao Programa Saúde na Escola (PSE).

Quadro 4. Panorama das teses e dissertações publicadas entre 2007 e 2016 que que se referem ao Programa Saúde na Escola (PSE). 42

Quadro 5. Quantitativo anual de instituições que aderiram ao Programa Saúde na Escola no Distrito Federal.

Quadro 6. Instituições escolares visitadas e suas respectivas Regionais Administrativas 48

Quadro 7. Distribuição quantitativa de professores entrevistados por Regional Administrativa e Escolas. 50

Quadro 8. Percepções de professores de Educação Física sobre o Programa Saúde na Escola. 54

Quadro 9. Percepções de professores de Educação Física sobre Promoção da Saúde. 57

Quadro 10. Percepções de professores de Educação Física sobre o tema Práticas corporais e Atividades Físicas e sua relação com a Promoção da Saúde.

Tabela 1. Caracterização dos participantes da pesquisa. 53

Figura 1. Esquema conceitual delimitador do estudo e norteador para a elaboração do roteiro de entrevista (elaborada pela autora). 47 


\section{LISTA DE SIGLAS E ABREVIAÇÕES}

$\begin{array}{ll}\text { ABRASCO } & \text { Associação Brasileira de Saúde Coletiva } \\ \text { CEPE } & \text { Comitê de Ética em Pesquisas com Seres Humanos } \\ \text { CODEPLAN } & \text { Companhia de Planejamento do Distrito Federal } \\ \text { DF } & \text { Distrito Federal } \\ \text { OMS } & \text { Organização Mundial da Saúde } \\ \text { OPAS } & \text { Organização Pan Americana de Saúde } \\ \text { PNPS } & \text { Política Nacional de Promoção da Saúde } \\ \text { PSE } & \text { Programa Saúde na Escola } \\ \text { SUS } & \text { Sistema Único de Saúde } \\ \text { UNB } & \text { Universidade de Brasília }\end{array}$


Página

LISTA DE QUADROS, TABELAS E FIGURAS ............................................ VIII

LISTA DE SIGLAS E ABREVIAÇÕES ............................................................... IX

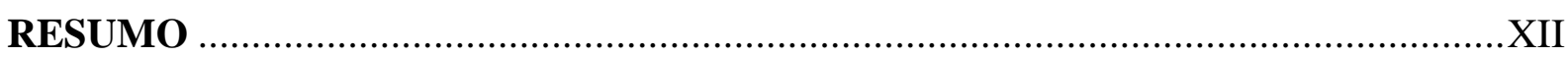

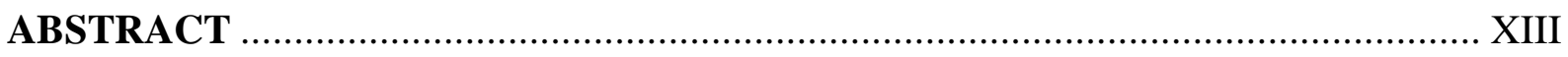

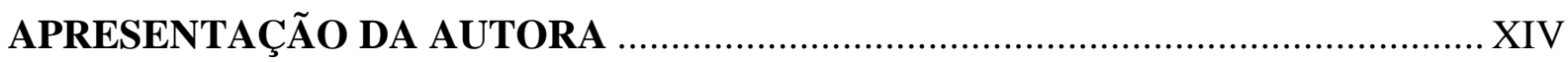

1. INTRODUÇÃ

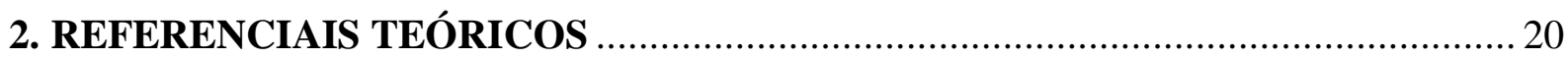

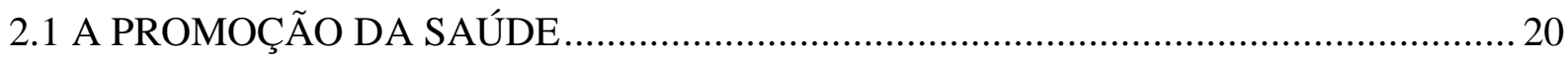

2.2 A SAÚDE NA ESCOLA E AS ESCOLAS PROMOTORAS DE SAÚDE ..................... 24

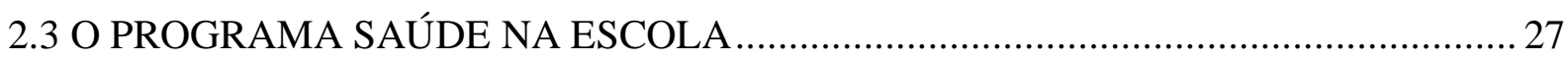

2.4 AS PRÁTICAS CORPORAIS E ATIVIDADES FÍSICAS COMO ELEMENTOS DE

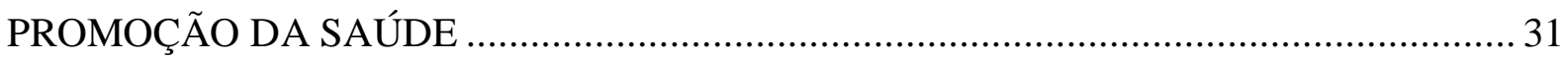

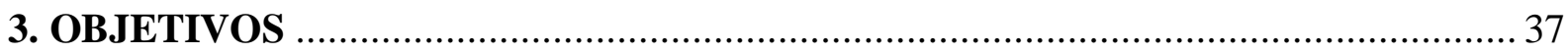

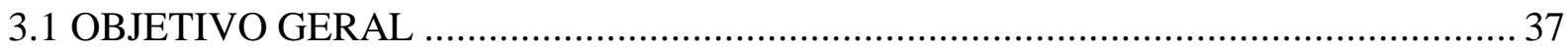

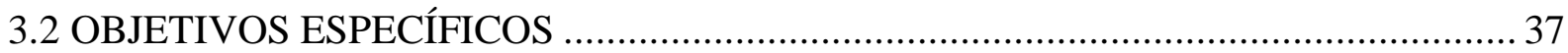

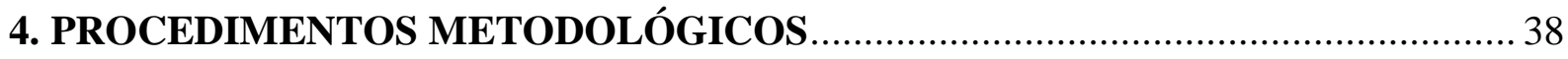

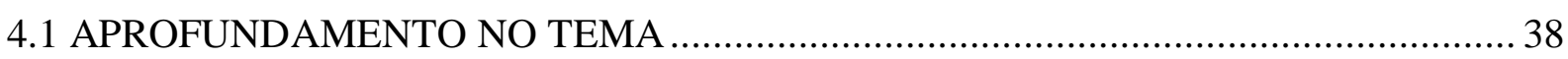

4.2 IMERSÃO NO CONTEXTO .......................................................................... 44

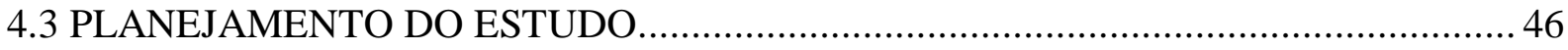

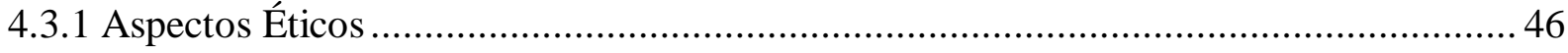

4.3.2 Elaboração do Roteiro de Entrevista .................................................................. 47

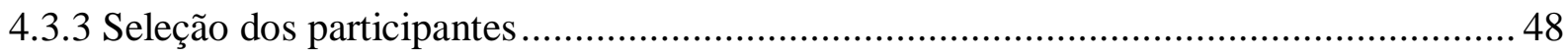

4.4 TRABALHO DE CAMPO E REALIZAÇÃO DE ENTREVISTAS .............................. 48

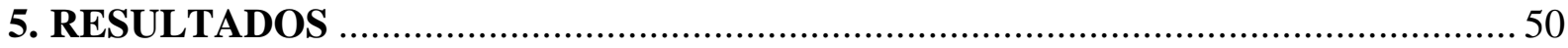

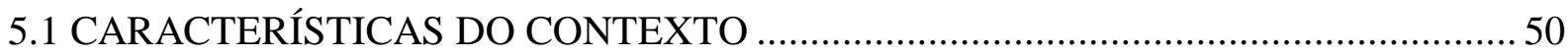

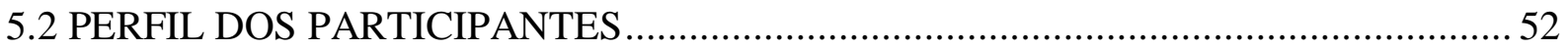

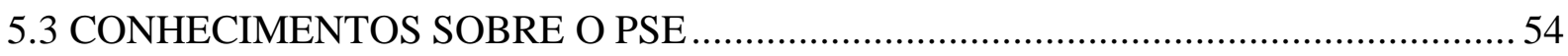

5.4 PERCEPÇÕES SOBRE A PROMOÇÃO DA SAÚDE ................................................ 57

5.5 PERCEPÇÕES SOBRE AS PRÁTICAS CORPORAIS E ATIVIDADES FÍSICAS E

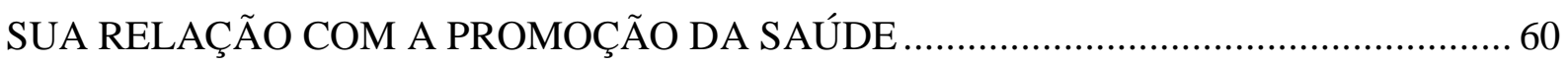

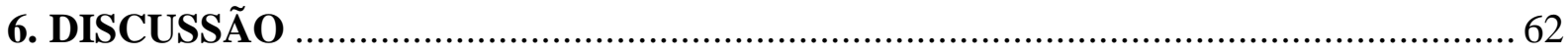


7. CONSIDERAÇÕES FINAIS 81

8. PERSPECTIVAS FUTURAS 83

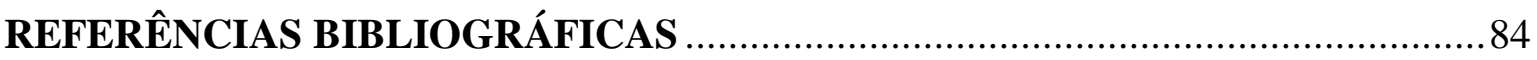

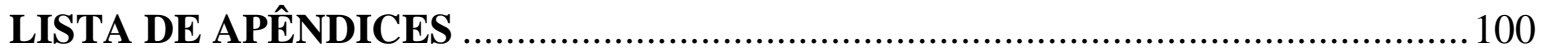

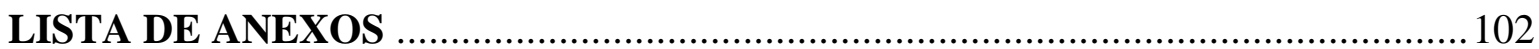




\section{RESUMO}

O Programa Saúde na Escola (PSE) é uma política intersetorial desencadeada a partir dos Ministérios da Saúde e Educação e tem como objetivo principal contribuir na formação integral de estudantes de escolas públicas por meio de ações de promoção, prevenção e atenção à saúde. O eixo Práticas Corporais e Atividades Físicas faz parte do conjunto de ações do PSE incluídas no componente de Promoção da Saúde e prevenção de doenças e agravos. Buscou-se identificar as percepções sobre o PSE, a Promoção da Saúde e a relação desses com as Práticas Corporais ou Atividades Físicas, a partir da visão de professores de Educação Física de escolas públicas que aderiram ao PSE. O estudo é descritivo, exploratório e de abordagem qualitativa. Foram entrevistados onze professores que atuam nas escolas que aderiam ao PSE no Distrito Federal (DF) durante os anos de 2014 e 2015. As falas foram transcritas, interpretadas e codificadas em categorias temáticas utilizando a técnica de análise de conteúdo descrita por Bardin (2007). Três categorias iniciais orientaram as entrevistas: o PSE; a Promoção da Saúde; e as Práticas Corporais e Atividades Físicas; que se desdobraram em nove subcategorias emergentes. Entre os principais achados identificou-se a inexistência de ações relacionadas ao eixo de Práticas e Atividades Corporais no PSE-DF; o desconhecimento e a não participação dos professores de Educação Física no PSE-DF; a valorização do tema numa perspectiva reducionista restrita à esfera individual, comportamental, preventivista, onde o sujeito é responsabilizado por suas ações, e a desconsideração das situações de vulnerabilidade social. Alguns professores apresentaram elementos em seus discursos que aproximam suas percepções na perspectiva um pouco mais ampliada de Educação em Saúde. Em conclusão, o eixo de Práticas Corporais e Atividades Físicas não é uma realidade no cotidiano do PSE-DF. Os professores entrevistados desconhecem não só os referenciais teóricos de Promoção da Saúde que norteiam o programa, como o próprio programa em si. Neste sentido, considera-se que a articulação da comunidade escolar proposta no PSE é uma ferramenta potente na construção de ideias, aprendizados e melhoria na saúde dos envolvidos que ainda precisa ser efetivada. É necessário resignificar as ações do eixo de Práticas Corporais e Atividades Físicas e investir na pesquisa e na formação permanente centradas nos referenciais de Promoção da Saúde e no desenvolvimento de competências adaptadas para esse trabalho transformador e desafiador. Só assim seremos capazes de promover Educação e Saúde e de desenvolver mecanismos para legitimar os ideais do PSE de propiciar uma educação cidadã e integral para as crianças e jovens brasileiros.

Palavras-chave: Educação em Saúde. Programas de Saúde. Saúde Escolar. 


\begin{abstract}
The School Health Program (PSE for its name in Portuguese) is an intersectional policy induced by the Ministries of Health and Education and its main aim is to contribute to the integral formation of students from public schools through health promotion, prevention and care. Body Practices and Physical Activities compose an axis of the PSE set of actions, included in the component of health promotion and diseases and disorders prevention. This study sought to identify the perceptions related to the PSE, the Health Promotion and the relationship of these with the Body Practices and Physical Activities, from the perspective of physical education teachers from public school who joined the PSE. This study is descriptive, exploratory and has a qualitative approach. Eleven teachers who work in schools that adhered to the PSE in the Federal District (DF) during the years of 2014 and 2015 were interviewed. The speeches were transcribed, interpreted and codified into thematic categories using the content analysis technique described by Bardin (2007). Three initial categories guided the interviews: the PSE; the health promotion; and the body practices and physical activities; which unfolded in nine emerging subcategories. Among the main findings we have the lack of actions related to the Body Practices and Physical Activities in PSE-DF; the ignorance about and non-participation of physical education teachers in the PSE-DF; a reductionist perspective of the theme restricted to individual, behavioral and preventive sphere, where the subject is responsible for his actions; and the disregard about the social vulnerability situations. There were elements in some teacher's speeches that brought their understanding closer to a broader perspective of health education. In conclusion, the axis of Body and Physical Activities practices are not a reality in the PSE-DF. Teachers interviewed are unaware not only of the theoretical framework of health promotion that guides the program, but of the program itself. In this sense, the articulation of the school community proposed by the PSE is considered a powerful tool in building ideas, learning and improving health of those involved, but still needs to be implemented. The understanding related to Body Practices and Physical Activities need to be extended, there must be investment in research and continuing education focused on the Health Promotion referential, and we need to develop skills adapted to this transforming and challenging work. Only then we will be able to promote education and health and to develop mechanisms to legitimize the PSE ideals of providing citizenship and integral education for children and young Brazilians.
\end{abstract}

Keywords: Health Education. Health Programs. School Health. 


\section{APRESENTAÇÃO DA AUTORA}

Com objetivo de evidenciar o processo de elaboração da presente pesquisa e os motivos que me levaram a escolher o tema abordado, inicio a dissertação expondo o panorama relativo aos aspectos da minha trajetória de vida, situando de onde falo, enquanto sujeito integrante do processo da pesquisa, onde reforço o processo de descobertas e aprendizados ocorrido com o estudo dos temas que nortearam a elaboração da pesquisa.

Meu interesse pela Educação Física começa com minha inserção na prática esportiva como atleta de handebol e resulta em minha formação superior na área. Antes de seguir, é importante destacar uma experiência marcante no percurso de ingresso ao Ensino Superior, quando tive a oportunidade de estudar informática no curso técnico profissionalizante do Instituto Federal de Educação, Ciência e Tecnologia do Ceará por meio de um dos primeiros sistemas de cotas no Brasil: uma seleção com vagas exclusivas para jovens de escolas públicas da periferia de Fortaleza. Essa experiência foi um divisor de águas ao resultar na fundação da Pirambu Digital - um empreendimento coletivo, com colegas do curso e do bairro (Pirambu), na área de tecnologia, com a perspectiva social, onde os beneficiados pelos cursos deveriam retribuir a oportunidade concedida, participando da formação de outros jovens, formando uma "corrente do bem".

Na graduação em Educação Física aproveitei as diversas oportunidades e participei de programas de pesquisa e extensão que aguçaram meu interesse pela formação continuada, contribuindo para que a pós-graduação stricto-sensu fosse hoje, uma realidade. Dois anos após meu ingresso no mestrado, repletos de esforço e um processo de aprendizado árduo mas gratificante, posso afirmar que valeu a pena!

O percurso realizado nesses dois anos ampliou meu olhar sobre as questões de saúde e educação e teve como fio condutor a minha imersão nas Ciências Sociais e Humanas e em aspectos da metodologia qualitativa de pesquisa. Tive oportunidades de aprender sobre diversos temas relacionados aos Campos da Educação Física e da Saúde Coletiva na perspectiva da Promoção da Saúde e dos Determinantes Sociais da Saúde. As primeiras aproximações com esses novos olhares e a desconstrução do modelo de ciência pautado na neutralidade do investigador exigiram momentos de autoreflexão sobre meu papel social enquanto pesquisadora. Os dias de estudos em curso têm sido de aprendizados constantes, e da certeza de que não aprendi tudo e nem saberei tudo.

Durante o tempo de realização do mestrado, presenciei tempos históricos do meu país que me fizeram refletir, me posicionar, pensar de forma coletiva e relacionar questões econômicas, políticas e sociais em meu contexto profissional e acadêmico. Minha dissertação 
nasce em um contexto de luta pela Democracia no Brasil. Em diversos momentos do processo de escrita deste trabalho pude realizar reflexões sobre os fatos cotidianos, pois, mesmo que de forma indireta, os processos de escrita em conjunto com o amadurecimento adquirido estão associados com os acontecimentos em meu entorno.

Entre tantos aprendizados que tive nesse percurso destaco a possibilidade de ampliar meus pensamentos para aspectos macrocontextuais, "sair de dentro de uma caixinha", analisar meu papel enquanto acadêmica, profissional, cidadã e inquietar-me com as injustiças sociais, engradecendo minha formação e futuras atuações profissionais. Está sendo um processo de intenso amadurecimento e aprendizado marcado por erros, acertos, aproximações com novos referenciais e pelo sempre e fundamental estímulo dado por professores e professoras que encontro nessa caminhada.

Interpreto que o processo do mestrado foi uma grande quebra de paradigma em minha formação que possibilitou descobertas e a ampliação da visão de mundo. Percebi a relevância de desenvolver o pensamento complexo, capaz de relacionar, contextualizar e religar diferentes saberes ou dimensões da vida. A humanidade precisa de mentes mais abertas, escutas mais sensíveis, e de pessoas responsáveis e comprometidas com a transformação de si e do mundo.

Desta caminhada resulta o interesse no Programa Saúde na Escola (PSE); um programa de abrangência nacional que visa contribuir para a formação integral dos estudantes por meio de ações de Promoção à Saúde; e o questionamento sobre o papel social dos professores de Educação Física na Promoção da Saúde em ambiente escolar. Tais temas possuem vínculos com os campos científicos da Educação Física e da Saúde Coletiva, fazendo-se necessário seu estudo para o delineamento do estudo.

Ciente dos paradigmas dominantes na formação em Educação Física, que refletem uma visão biomédica da saúde relacionada à aptidão física onde a prática de atividade física prescritiva e individualizada é utilizada de forma preventivista em detrimento de uma visão ampliada de saúde que alça as práticas corporais ao patamar promotor da saúde, em estreita relação com contextos amplos da vida tais como os Determinantes Sociais da Saúde e os princípios de empoderamento, autonomia e participação social; me senti motivada a compreender os modelos que permeiam o desenvolvimento das atividades do eixo práticas corporais e atividades físicas no PSE, bem como a percepção dos profissionais envolvidos nesse processo.

É importante deixar claro que não concebo o trabalho ora apresentado como algo acabado ou finalístico mas considero apresentar uma contribuição científica relevante sobre as percepções de professores de Educação Física sobre os fenômenos das Práticas Corporais e 
Atividades Físicas e sua relação com a Promoção da Saúde no contexto escolar. Não obstante, mais que as reflexões teóricas, espero que as considerações aqui apresentadas possam se refletir na reformulação da formação superior em saúde; nas tomadas de decisão no cotidiano do PSE e nas práticas dos professores de Educação Física, produzindo resultados sociais promotores da saúde e da vida.

Diante da desvalorização da saúde e da educação enquanto direitos sociais, e do avanço do poder econômico e das ideologias neoliberais e conservadoras em nosso país, "é preciso ter força, é preciso ter raça; é preciso ter gana sempre...”. Vamos à luta! 


\section{INTRODUÇÃO}

O Programa Saúde na Escola (PSE) é uma política pública intersetorial que sinaliza para a articulação entre Estado e sociedade no processo de implantação e desenvolvimento de ações no âmbito da educação e da saúde que resultem na melhoria da qualidade e condições de vida das comunidades escolares (BRASIL, 2011). As práticas corporais e atividades físicas fazem parte do conjunto de ações a serem desenvolvidas no Programa, incluídas no componente de Promoção da Saúde e prevenção de doenças e agravos (BRASIL, 2015).

Ao reconhecer a relação das práticas corporais e atividades físicas com a Promoção da Saúde e a prevenção de doenças é importante destacar as diferenças conceituais - que por sua vez orientam a formação e as práticas profissionais - entre os termos. Considerá-los como sinônimos ou agrupá-los num mesmo eixo de ação ou componente significa ignorar o contexto histórico e as concepções vigentes de saúde presentes nas aproximações desses temas no ambiente escolar (CARVALHO, 2008).

As atividades físicas ${ }^{1}$ passaram a desenvolvidas de forma sistemática nas escolas brasileiras através das aulas de educação física a partir de meados do século XIX. Influenciadas pelos movimentos ginásticos europeus, as aulas eram centradas em técnicas militaristas e concepções médico-higienistas e sanitárias. A partir da década de 1980 a intervenção esportivista, caracterizada por uma concepção competitiva pautada na detecção de talentos, ganha hegemonia nas aulas de Educação Física escolar. Nos anos 1990 a perspectiva do fitness (aptidão física) ganha força como sinônimo de saúde e de prevenção de doenças (KUNZ, 1991; FERREIRA, 2001). Em todos esses momentos, movimentos contrahegemônicos que visavam destacar os aspectos sociais da prática corporal, incluindo os movimentos pedagógicos renovadores, a perspectiva do lazer e a saúde na esfera coletiva, estiveram presentes (BRACHT, 2000; BAGRICHEVSKY, 2007).

Nesse mesmo período, os avanços conceituais em torno do tema da saúde foram sofrendo mudanças. Utilizada pela primeira vez em 1945 a Promoção da Saúde visava definir uma das quatro funções da medicina moderna, juntamente com a prevenção das doenças, o tratamento dos doentes e a sua reabilitação (CANEL; CASTRO, 2008). A partir de 1970, a

\footnotetext{
${ }^{1}$ Uma grande diversidade de termos e conceitos - a saber: esporte, exercício, atividade física, práticas corporais, treinamento físico, desporto, ginástica, prática física, motricidade e outros - são utilizados para definir o corpo em suas possibilidades de movimento (NOGUEIRA, 2014). A problematização (aproximações e distanciamentos) dessas questões epistemológicas será realizada mais adiante na discussão do trabalho. No entanto, por hora, é importante destacar que iremos adotar os termos práticas corporais e atividades físicas em consonância com os documentos oficiais do PSE (BRASIL, 2007a) e da Política Nacional de Promoção da Saúde (BRASIL, 2006; BRASIL 2014).
} 
Promoção da Saúde desponta internacionalmente como uma "nova concepção de saúde" não centrada na doença, mas sim voltada para a mudança individual dos estilos de vida (HEIDMANN et al., 2006). A partir da I Conferência Internacional de Promoção da Saúde realizada em 1986 em Ottawa, no Canadá, a determinação social e econômica da saúde é reconhecida, fundamentando esses determinantes na ampla causalidade do processo saúdedoença (OTTAWA, 1986). Atualmente a Promoção da Saúde consiste em um modelo teóricoconceitual e uma estratégia que subsidia políticas e práticas em saúde pública em todo o mundo considerando os determinantes sociais da saúde e a participação dos sujeitos no processo de construção das condições de vida e saúde de indivíduos e coletividades (CARVALHO; GASTALDO, 2008; BARRY et al., 2009).

Não obstante os avanços conceituais, as aproximações dos temas da saúde no ambiente escolar tem sido marcadas por uma concepção ainda vigente e hegemônica de saúde limitada às vertentes higienista e preventivista, numa perspectiva de educação em saúde que se resume à mera transferência de informações (GONÇALVES et al., 2008). Tradicionalmente a educação em saúde tem características lineares, pautadas na transmissão do conhecimento e na experiência do médico/educador, centrada na relevância suprema do conteúdo ensinado, onde se espera que os educandos o absorvam sem modificações e que o reproduzam fielmente (FIGUEIREDO; RODRIGUES-NETO; LEITE, 2009). Já as práticas na Educação Física escolar brasileira continuam isoladas em ações voltadas para o aumento da atividade física numa perspectiva estritamente comportamental (CARVALHO, 2008).

Para que a Educação Física opere em consonância com o movimento da Promoção da Saúde, as práticas corporais devem ser compreendidas como um fenômeno que apresenta conexão com a cultura local, com o território onde os indivíduos moram, com os espaços de convivência e construção humana, com a família, as associações comunitárias, os espaços de decisões políticas, os equipamentos públicos de lazer, o trabalho, dentre outros aspectos (BUSS; PELLEGRINI FILHO, 2007). Devem ser desenvolvidas por meio de uma abordagem ampliada que valoriza e reconhece os contextos sociais e históricos e a complexidade do fenômeno do movimento corporal intencional e consciente (BRASIL, 2015), através de práticas voltadas para o desenvolvimento integral das habilidades e capacidades de crianças, jovens, adultos e idosos por meio da interação entre a família, a comunidade e a sociedade (VILARTA, 2004).

Para que isso ocorra é necessário superar o paradigma hegemônico e a superficialidade teórica da abordagem da saúde na educação física escolar. Uma forma de viabilizar esse avanço nas bases conceituais é através da aproximação entre os Campos da Saúde Coletiva e da Educação Física de modo a (re)organizar os saberes (e práticas) 
relacionados à saúde na escola para além de uma abordagem isolada ou fragmentada (KNUTH; LOCK, 2014). Dada a sua complexidade, a saúde não pode ser debatida por uma única disciplina ou área do conhecimento (LOCK, 2011). Há que se alargar os conhecimentos para além dos saberes biológicos e incluir as ciências sociais e humanas para que o professor de Educação Física se aproprie, construa e medeie as práticas na tentativa de tornar seus alunos críticos, autônomos e cidadãos, sabedores de seus direitos e não meros praticantes ou reprodutores de atividades físicas descontextualizadas (MEZZAROBA, 2012).

Sendo assim, se faz necessário conhecer as percepções que embasam os discursos e as práticas relativas à atividade física e saúde no ambiente escolar; em especial as apresentadas por atores responsáveis por desenvolver programas de promoção da saúde como é o caso do PSE. Desvelar essas percepções possibilita conduzir novos debates levando em consideração as aproximações que tendem a surgir entre os campos científicos na contemporaneidade moderna e complexa (BAUMAN, 2001; MORIN, 2011). Para tal consideraremos aqui algumas abordagens epistemológicas dos campos da Educação Física e da Saúde Coletiva; em particular a Promoção da Saúde. Entendemos por percepção as impressões, os conhecimentos e consciência dos participantes da pesquisa a respeito dos temas em questão.

Nesse sentido, a dissertação está organizada por tópicos (capítulos) teóricos que proporcionam uma aproximação com temas importantes concernentes ao estudo. O referencial teórico está dividido em quatro seções e tem como tópico inicial a explanação sobre o tema da Promoção da Saúde. Entendemos a Promoção da Saúde como um modelo teórico e prático que definido como o processo de capacitar a população para obter um melhor controle na produção do cuidado em saúde que reconhece os determinantes sociais da saúde como quesitos fundamentais no cuidado em saúde levando em consideração os aspectos sociais tendo como pré-requisitos: a justiça social, a eqüidade, a educação, o saneamento básico, a paz, a habitação e os salários apropriados. O ponto de partida para apresentação deste tema estará pautado em seus aspectos históricos.

O tema Saúde na Escola está abordado tendo como estruturas basilares: o movimento das Escolas Promotoras de Saúde e o PSE. Além de buscarmos um resgate histórico sobre os assuntos, buscamos abordar a importância do ambiente escolar na relação: saúde x escola. No terceiro tópico procuramos situar (apresentar) uma breve explanação de como funciona o PSE na realidade brasileira. Na última seção é feita uma breve explanação das Práticas Corporais e Atividades Físicas e suas relações com a Promoção da Saúde, no contexto do Campo da Educação Física e os tensionamentos existentes. A descrição detalhada da cada tema será abordada a seguir. 


\section{REFERENCIAIS TEÓRICOS}

\subsection{A PROMOÇÃO DA SAÚDE}

As referências teórico-conceituais que norteiam a Promoção da Saúde são diversas, mas o fio condutor comum é o esforço para superar abordagens tecnicistas e medicalizantes sobre os problemas de saúde (MAGALHÃES, 2016). Assim, a Promoção da Saúde pode ser entendida como um amplo movimento social que articula políticas públicas com a participação popular de forma a permitir que fatores políticos, econômicos, do meio ambiente e socioculturais, além dos biológicos, sejam favoráveis à saúde (OPAS, 1986).

A Promoção da Saúde é envolvida por uma complexidade desafiante a estudiosos e profissionais de diversas áreas que engloba a articulação e arranjos intersetoriais na gestão pública, empoderamento da população, capacitação e desenvolvimento de competências e habilidades, acesso à informação, estímulo à cidadania ativa, dentre outros, para que os sujeitos reconheçam os problemas que os afetam e suas causas, e possam advogar por políticas públicas saudáveis (KELLEHER, et al., 2002; MORETTI et al., 2009).

No contexto histórico, as primeiras referências sobre o conceito de Promoção da Saúde datam de 1945, quando o sanitarista canadense Henry Sigerist concebeu as quatro funções da medicina: Promoção da Saúde, Prevenção das Doenças, Tratamento dos doentes e Reabilitação. Para esse estudioso, a Promoção da Saúde significava por um lado, ações de educação em saúde e por outro, ações estruturais do Estado para melhorar as condições de vida (WESTPHAL, 2013). Henry Sigerist atribuiu as seguintes finalidades para a Promoção da Saúde: envolve-se com fatores socioambientais, com medidas políticas e trabalho comunitário, com a prevenção (tratamento de doenças) e com a reabilitação (CANEL; CASTRO, 2008).

Em meados dos anos 70, o relatório Lalonde, divulgado no Canadá, formaliza uma concepção para o termo Promoção da Saúde visando ampliar o campo de atuação da Saúde Pública, acrescentando ações assistencialistas, preventivas e programas educativos voltados para mudanças comportamentais e de estilo de vida (CANEL; CASTRO, 2008). Foi nesse período que a Promoção da Saúde despontou internacionalmente como uma "nova concepção de saúde", não centrada na doença. No entanto, apesar do avanço de sua notoriedade, a "nova" abordagem tinha o enfoque voltado para a mudança dos estilos de vida, com ênfase na ação individual, adotando-se uma perspectiva comportamental e preventivista (Heidmann et al., 2006). 
Em 1978 a Declaração de Alma Ata afirma preceitos importantes para a Promoção da Saúde, a qualidade de vida e a paz mundial, reconhecendo: a saúde como um direito humano fundamental; a responsabilidade dos setores sociais e econômicos nas ações em saúde; e o direito e dever da população em participar coletiva e individualmente do planejamento e execução dos cuidados primários em saúde (OMS, 1978).

Embora desde a segunda metade do século XX a saúde e a doença tenham sido reconhecidas como resultantes determinados política, social e economicamente em decorrência de situações de pobreza, desemprego, habitação e outros fatores de iniquidades, é a partir da $1^{\text {a }}$ Conferência Internacional de Promoção da Saúde realizada em novembro de 1986 em Ottawa, no Canadá, que a Promoção da Saúde se consolida como um marco referencial no desenvolvimento dessas ideias e de novas práticas de saúde em todo o mundo (ABRASCO, 2016).

A Carta de Ottawa - documento referência resultante do processo de discussão e construção coletiva dos conceitos fundamentais sobre a Promoção da Saúde na $1^{\text {a }}$ Conferência Internacional - elenca o conceito ampliado de Promoção da Saúde relacionando-o ao bem estar dos indivíduos e fundamentado na ampla causalidade do processo saúde-doença (OTTAWA, 1986). Esse documento define a Promoção da Saúde como o processo de capacitação da comunidade para atuar na melhoria de sua qualidade de vida e saúde, incluindo a participação popular no controle deste processo (OPAS, 1986).

A partir de Ottawa, outras conferências foram realizadas com as correspondentes declarações ou cartas, que sintetizam suas conclusões e recomendações. Dentre as conferencias Internacionais estão: Adelaide (1988), Sundsvall (1991), Jakarta (1997), México (2000), Bangkok (2005), Nairóbi (2009) e Helsink (2013). Entre as Regionais podemos citar: Bogotá (1992), do Caribe (1993), e Suíça (1998). Cada uma delas vem desempenhando importante papel na manutenção da motivação e do interesse sobre o tema, promovendo avanços significativos em abordagens mais efetivas e a contínua ampliação dos campos de ação (BUSS; FERREIRA, 2000; WESTPHAL, 2013).

Nessa perspectiva, hoje as principais estratégias e recomendações para implementar as práticas de Promoção da Saúde são: a garantia de políticas públicas saudáveis; a reorientação dos serviços de saúde; a criação de ambientes sustentáveis; o desenvolvimento da capacidade dos sujeitos; e o fortalecimento de ações comunitárias e da participação popular (CARVALHO; GASTALDO, 2008); centradas em princípios e valores como: a solidariedade, a equidade, a democracia, a cidadania, o desenvolvimento sustentável, a participação e ação conjunta, entre outros (ABRASCO, 2016). 
Em síntese, o termo Promoção da Saúde foi marcado por duas abordagens diferentes: uma conservadora, caracterizada pela teoria comportamentalista, predominante nos anos setenta; e outra mais moderna, fundamentada em uma corrente socioecológica, predominante nas discussões teóricas a partir dos anos oitenta (FERREIRA, CASTIEL, CARDOSO, 2011).

Atualmente, o enfoque abrangente da Promoção da Saúde busca identificar os macrodeterminantes do processo saúde-doença, procurando transformá-los favoravelmente na direção da saúde e da diminuição das desigualdades socioeconômicas, em especial nos países subdesenvolvidos (CAMARGO, 2012). Para subsidiar as políticas, programas, estratégias e ações em Promoção da Saúde, foram definidos sete princípios norteadores, a saber: concepção holística, intersetorialidade, empoderamento, participação social, eqüidade, ações multiestratégicas e sustentabilidade (OMS, 1998).

As ações de Promoção da Saúde devem estar voltadas para uma perspectiva contextual ampla, histórica e coletiva e resgatam a concepção de saúde como produção social buscando desenvolver políticas públicas por meio de ações de âmbito universal que não restrinjam a saúde à ausência de doença, mas que sejam capazes de atuar sobre seus determinantes (SÍCOLI; NASCIMENTO, 2003; PELLEGRINI FILHO; BUSS, 2007).

No Brasil, as discussões sobre Promoção da Saúde ocorrem conjuntamente com o Movimento da Reforma Sanitária, com a instituição da Constituição Federal de 1988 e com a criação do Sistema Único de Saúde (SUS), todos contemplando o conceito de saúde como direito social e visando reduzir as iniquidades em saúde (MALTA; CASTRO, 2009). Não obstante, a institucionalização da Promoção da Saúde ocorre apenas em 2006 com a publicação da Política Nacional de Promoção da Saúde (PNPS).

Instituída pela Portaria n 687, de 30 de março de 2006, a PNPS representa o esforço conjunto do Ministério da Saúde e de setores da academia para sistematizar e apresentar os objetivos, as diretrizes, e as estratégias de implementação no processo de definições das atribuições das esferas de gestão federal, estaduais e municipais para as ações de Promoção da Saúde no âmbito do SUS (GUERRA et al., 2015).

A versão inicial da PNPS define sete ações prioritárias dentre as quais figuram as práticas corporais e atividades físicas, em conjunto com a alimentação saudável; a prevenção e o controle do tabagismo; a redução da morbimortalidade em decorrência do uso abusivo de álcool e outras drogas; a redução da morbimortalidade por acidentes de trânsito; a prevenção da violência e o estímulo à cultura de paz; e a promoção do desenvolvimento sustentável (BRASIL, 2006).

Muito embora a discussão e a publicação da PNPS tenham servido como dispositivos para ampliar o debate sobre os determinantes sociais no processo saúde-doença; para 
estimular a articulação diferentes áreas técnicas, programas e políticas a partir da abordagem da Promoção da Saúde; e para fomentar atividades de promoção em todos os níveis do SUS (MALTA et al., 2014; MALTA; CASTRO, 2009); há que se destacar a pequena participação social na sua elaboração e a permanência de uma lógica preventivista, centrada na adoção de comportamentos saudáveis a nível individual (ROCHA, et al., 2014).

Desta forma, o comitê gestor da PNPS propôs uma ação de revisão da política que contemplasse as transformações sociais, os avanços e os desafios identificados no período, incluindo a necessidade de articulação de agendas entre diversos setores, o fortalecimento da participação social visando garantir a representatividade democrática, o favorecimento da visibilidade das diferentes realidades regionais, e a problematização das práticas de Promoção da Saúde implementadas em diferentes contextos do território brasileiro (ROCHA, et al., 2014). A versão revista da PNPS publicada em 2014 destaca princípios e valores em promoção da saúde e enfatiza a promoção da equidade e a melhoria das condições de vida como elementos centrais na redução das vulnerabilidades e riscos à saúde decorrentes dos determinantes sociais, econômicos, políticos, culturais e ambientais (BRASIL, 2014a).

Após uma década da publicação da PNPS muitos são os avanços, mas também os desafios. Dentre os avanços podemos citar algumas ações estruturantes, por exemplo, o aumento de políticas e programas de Promoção da Saúde, inclusive o PSE (MALTA et al., 2016). Dentre os desafios destaca-se a importância de valorizar sua consolidação enquanto política e prática orientada por valores e princípios de participação, intersetorialidade e equidade, fundamentados no SUS e nos movimentos internacionais de Promoção da Saúde (SPERÂNDIO, et al., 2016).

Apesar da abordagem inovadora e do potencial para uma mudança no contexto social das populações, principalmente as mais vulneráveis, os conceitos e princípios da Promoção da Saúde ainda estão longe de serem plenamente compreendidos e praticados pelos profissionais da saúde (TEIXEIRA et al., 2014). É perceptível a diferença de ênfases e entendimentos do termo da Promoção da Saúde presente nos debates, documentos institucionais e práticas em serviço (SILVA; BAPTISTA, 2014). A heterogeneidade de operacionalizações das ações pautadas em diferentes vertentes teórico-conceituais de Promoção da Saúde e a intensa fragmentação de políticas, programas, ações e práticas se constituem, no âmbito local, em importantes entraves no atual modelo de gerenciamento da saúde (BUSS; PELLEGRINI FILHO, 2007).

A Promoção da Saúde tem um papel que vai além do impacto nas condições de saúde da população; seus direcionamentos devem buscar transformar o perfil de engajamento comunitário e o bem estar social. Nesse processo, múltiplos recursos devem ser articulados e 
integrados levando em consideração diferentes interesses, necessidades e motivações dos atores sociais no cenário local (MACDONALD; VEEN; TONES, 1996). A participação de usuários e comunidades é um componente primordial na medida em que favorece o mapeamento de demandas e oportunidades, a colaboração entre múltiplos parceiros, a responsabilização coletiva em torno dos resultados e um maior aprendizado social (MAGALHÃES, 2016). O profissional promotor de saúde deve trabalhar para reduzir as iniquidades por meio de ações que envolvam o desenvolvimento de políticas saudáveis, a criação de ambientes favoráveis à saúde, o reforço da ação comunitária, o desenvolvimento de habilidades pessoais e a reorientação dos serviços de saúde (DEMPSEY et al., 2011; OPAS, 1986).

\subsection{A SAÚDE NA ESCOLA E AS ESCOLAS PROMOTORAS DE SAÚDE}

A criação de ambientes favoráveis à saúde é uma das principais estratégias de Promoção da Saúde desde a Carta de Ottawa, em 1986. Nessa perspectiva, surgem movimentos como: Cidades e Municípios Saudáveis, Universidades Saudáveis e Escolas Saudáveis (WESTPHAL, 2000; SILVA; WESTPHAL; MENDES, 2000; MELLO; MOYSÉS; MOYSÉS, 2010).

O ambiente escolar é reconhecidamente um espaço privilegiado para se desenvolver a Promoção da Saúde dada sua capilaridade e abrangência, onde grande parte das crianças de um país irão frequentar (IPPOLITO-SHEPHERD, 2003). Além disso, a despeito de diversas significações no que diz respeito à sua função social, missão e organização, a escola é fundamentalmente reconhecida como um espaço social na qual se desenvolve processos de ensino e aprendizagem que articulam ações educativas para construir valores envolvendo seu território e seu entorno (LIBERAL, 2005). A Promoção da Saúde no ambiente escolar se constitui como um importante elemento agregador no fortalecimento da autonomia, do empoderamento e da participação crítica e criativa dos sujeitos (SANTOS; BÓGUS, 2007).

Uma das primeiras iniciativas relacionadas ao tema da saúde na escola ocorreu no início do século XIX, quando o médico alemão Johann Peter Frank elaborou o System Einer Vollständigen Medicinischen Politizey (Um sistema completo de Política Médica). Esse sistema publicado num tratado de higiene e saúde pública contemplava múltiplos aspectos da saúde pública e individual tais como casamento, procriação, puerpério, saúde infantil, saúde escolar, medicina militar, doenças infecto-contagiosas, vestuário, demografia, esgotos, suprimento de água, prevenção de acidentes, dentre outros, compreendidas numa perspectiva higienista, da polícia médica (FONSECA, 1985). 
No Brasil, a saúde escolar tem seu marco inicial no século XX fundamentada na modernização e higienização do espaço urbano e na identificação da escola como espaço de disseminação de regras de civilidade e de higiene, condições fundamentais à prevenção e ao combate das epidemias. Assim, a saúde escolar nasce determinada numa lógica de vigilância epidemiológica e sanitária e assistência clínico-terapêutica, com conteúdos normativos prédefinidos sobre o que deveria ser feito e discutido nas aulas (SILVA; BODSTEIN, 2016).

A seguir, um modelo biomédico especializado ganhou espaço baseado em uma conjuntura teórica centrada na prática assistencialista, curativa e hospitalocêntrica que valoriza a medicina especializada e o acesso a serviços de maior complexidade. Esse modelo compartimentalizado e individualista medicaliza o fracasso escolar (SILVA, 2010).

Outro modelo é o do espaço escolar como um equipamento dos serviços de saúde. Pautado na criação de serviços de ambulatório para atendimento na escola e na convivência de profissionais de saúde e de educação no mesmo espaço físico (a escola), tem o conceito de saúde como ausência de doença com prioridade para o tratamento e a cura. Suas principais características são práticas assistenciais de saúde isoladas e descontextualizadas da rede de serviços de saúde, indo na contramão dos princípios do SUS, sem participação social e intersetorialidade (SILVA, 2010).

Por fim, o modelo de Promoção da Saúde começa a ganhar corpo na escola, visando estimular o protagonismo do sujeito a partir de ações descentralizadas que valorizam e articulam os diferentes conhecimentos (os especializados e os populares). Essa perspectiva faz com que a saúde e a educação compartilhem metas, objetivos e recursos, num processo de parceria com poder equânime de decisão. Tendo forte base comunitária, esse modelo dá ênfase ao contexto e à territorialização do espaço escolar valorizando o conceito de rede de saúde (SILVA, 2010).

Percebemos assim que os modelos teóricos da saúde escolar apresentam diferentes concepções no último século (SILVA, 1991; BODSTEIN, 2007). Levando em consideração a deterioração das condições de vida das populações que vivem nos países em desenvolvimento, em especial das crianças, a conferencia de Bogotá em 1992, a primeira na América Latina, teve papel fundamental de trazer a discussão da Promoção da Saúde relacionada à equidade e ao desenvolvimento sustentável para o continente. Desde então, a saúde na escola vem se fortalecendo como uma ação relevante e viável nas intervenções sociais na área de saúde pública numa perspectiva Promotora da Saúde (CANDEIAS, 1997).

Com o propósito de fortalecer a capacidade dos países membros na América Latina e Caribe na área da saúde escolar, em 1995 a OPAS lançou a iniciativa das Escolas Promotoras de Saúde. Com o objetivo de revisar os modelos de saúde escolar, a iniciativa também 
questionava a relação autoritária da saúde com a educação nos modelos de saúde escolar. Assinalava que as dificuldades de avançar não seriam superadas com o setor da educação em papel passivo e submisso às ordens prescritivas da saúde (IPPOLITO-SHEPHERD, 2003).

Tendo como fundamento o conceito da Promoção da Saúde que considera os determinantes das condições sociais econômicos, culturais e ambientais da saúde, o movimento das Escolas Promotoras de Saúde contribui para que o tema da saúde escolar tivesse um avanço paralelo com o conhecimento técnico-cientifico e com o desenvolvimento sociopolítico, buscando suplantar, de forma gradativa, o paradigma tradicional biomédico e promovendo o fortalecimento de enfoques integrais de saúde escolar (GRACIANO et al., 2015).

Nesse sentido, uma Escola Promotora de Saúde precisa superar a perspectiva da supervisão à saúde, a definição de saúde como ausência de doença e sua perspectiva de responsabilidade individual (AERTS et al., 2004). Precisa adotar um enfoque voltado para a integralidade do ser humano e reconhecer que a oportunidade de educar, de capacitar, de desenvolver valores e de construir hábitos saudáveis é um desafio que se expande para toda comunidade escolar (SILVA et. al., 2014), devendo ocupar-se também da família, do espaço físico escolar e dos profissionais que atuam na educação (FIGUEIREDO; MACHADO; ABREU, 2010).

Pode ser dizer que o movimento das Escolas Promotoras de Saúde tem como principal característica conceitual e metodológica a incorporação da Promoção da Saúde e seus princípios na saúde coletiva, que envolve o entorno escolar, onde a implantação da proposta implica em atividades intersetoriais entre a instituição educativa, o setor saúde e a comunidade, com identificação das necessidades e linhas de enfrentamento pelos próprios envolvidos (CARDOSO; REIS; IERVOLINO, 2008). Assim, a Escola Promotora de Saúde deve: a) fomentar o desenvolvimento humano saudável e as relações construtivas e harmônicas; b) promover aptidões e atitudes para a saúde em um espaço físico seguro e confortável, com água potável e instalações sanitárias adequadas, e uma atmosfera psicológica positiva para a aprendizagem; e c) promover a autonomia, a criatividade e a participação dos alunos, bem como de toda a comunidade escolar (HARADA et al., 2003).

As ações realizadas nas Escolas Promotoras de Saúde devem promover a autonomia dos sujeitos por meio de abordagens multifatoriais, intersetoriais e interdisciplinares de forma a apoiá-los na identificação e superação dos obstáculos, fortalecendo o processo de tomada de consciência e de enfrentamento dos problemas vividos na realidade cotidiana (WIMMER; FIGUEIREDO, 2006). É ainda crucial reconhecer a escola como espaço social, institucional e político, permeado pela cultura - além de um espaço educativo formal - de forma a garantir o 
suporte e a sustentabilidade das estratégias de Promoção da Saúde, garantindo destaque a fatores indissociáveis como a interdependência entre a gestão, a formação e o processo de ensino e aprendizagem (REZENDE, 2007).

Para tal, é necessário desenvolver competências em Promoção da Saúde dentro e fora das salas de aula (BYDLOWSKI; WESTPHAL; PEREIRA, 2004). A formação permanente dos docentes e agentes de saúde é fundamental para que se modifique o paradigma tradicional da saúde escolar para uma educação baseada na saúde integral, que considera o ser humano dentro do seu ambiente familiar, comunitário e social; voltada para a criação e a manutenção de ambientes saudáveis; para a criação de vínculo com a comunidade de abrangência e para a provisão de serviços de saúde e de modos de vida saudáveis (ROCHA et. al., 2002; IPPOLITO-SHEPHERD, 2006; STEWART-BROWN, 2006).

Embora reconhecida como uma importante estratégia de Promoção da Saúde e utilizada em nível mundial para implantar políticas de Promoção da Saúde em vários países, estados, municípios ou serviços (HARADA et al., 2003) e, a despeito das mudanças aceleradas no contexto contemporâneo (BAUMAN, 2001), o modelo de escola que predomina atualmente nos países em desenvolvimento tem características conservadoras e reprodutoras (transmissão e internalização) de conhecimentos, de condutas e de habilidades específicas historicamente perpetuados por uma ordem vigente que impacta fortemente o espaço escolar e gera uma crise de múltiplos aspectos, dentre os quais o reforço de valores morais individualistas, com pouca motivação e desmobilização para o estudo (MOURA et al., 2007).

No Brasil, grande parte dos escolares ainda vivenciam ambientes nocivos à saúde, muitas vezes marcados por situações de exclusão social, incluindo situações de maus-tratos, abuso sexual, violência, drogas e acidentes, sem que a escola consiga modificar ou atuar sob esses múltiplos fatores de risco (CERQUEIRA, 2007).

\subsection{O PROGRAMA SAÚDE NA ESCOLA}

O Brasil é um país extremamente desigual, uma característica que remonta às origens históricas de colonização e adoção do modelo escravista e às dimensões continentais do país (IANNI, 1988). A despeito desse histórico, avanços recentes em alguns indicadores sociais e econômicos foram obtidos através de políticas e programas sociais desenvolvidos de forma mais sistemática a partir de 2002, quando o Governo Federal foi assumido pelo Partido dos Trabalhadores, de orientação ideológica de centro-esquerda e caráter progressista (MENICUCCI, 2011). Dentre as ações adotadas, diversas apresentam ligação com as esferas 
da educação e da saúde, consideradas como elementos fundamentais para a superação das iniquidades (DIAS et al., 2014).

No campo do desenvolvimento social e combate a fome e a miséria, tivemos a criação do Programa Bolsa Família (MAGALHÃES, 2015). No campo da saúde tivemos a implementação gradativa do SUS, o fortalecimento da atenção básica e sua articulação com o desenvolvimento social, a Promoção da Saúde e os Determinantes Sociais da Saúde (MENICUCCI, 2011; PAIM et al., 2012; PINTO et al., 2014). No campo da educação, o Programa Mais Educação, se constitui como estratégia para induzir a ampliação da jornada escolar e a organização curricular na perspectiva da Educação Integral (BRASIL, 2007b).

No mesmo sentido da formação integral, uma proposta intersetorial entre os Ministérios da Saúde e da Educação foi a criação do PSE, uma política pública que sinaliza para a articulação entre Estado e sociedade no processo de implantação e desenvolvimento de ações no âmbito da educação em saúde para melhoria da qualidade e condições de vida dos escolares, suas famílias e comunidade, a partir da articulação entre a Escola e a Unidade Básica de Saúde (BRASIL, 2007a).

É importante reconhecer que o PSE foi bastante influenciado por políticas anteriores tais como a Lei n ${ }^{\circ} 9.394$ de Diretrizes e Bases da Educação Nacional (BRASIL, 1996), que introduz os temas transversais de saúde, ética, meio ambiente, trabalho, consumo, orientação sexual e pluralidade cultural tendo em vista a formação cidadã dos estudantes; os Parâmetros Curriculares Nacionais (BRASIL, 1997), que buscam apontar metas de qualidade que ajudem o aluno a enfrentar o mundo atual como cidadão participativo, reflexivo e autônomo, conhecedor de seus direitos e deveres; e a própria PNPS (BRASIL, 2006).

Assim, a esfera educacional é considerada um espaço privilegiado por possuir em seus contextos aspectos substancialmente abrangentes ramificados em perspectivas complexas que aproximam o movimento da Promoção da Saúde como um correligionário com objetivos de fortalecer as capacidades dos cidadãos na tomada de decisões favoráveis à sua saúde, para a criação de ambientes saudáveis e para a consolidação de uma política intersetorial voltada para a qualidade de vida, pautada no respeito e tendo como foco a construção de uma nova cultura da saúde (BRASIL, 2004).

Atualmente os documentos oficiais que normatizam o PSE são: o Decreto no 6.286 de 05 de dezembro de 2007, que instituiu o PSE, suas finalidades e regulamenta as atividades para a saúde no âmbito escolar; a portaria $n^{0} 1.861$, de 04 de setembro de 2008 que regulamenta a responsabilidade orçamentária do Ministério da Saúde com os municípios que aderem ao PSE; e mais recentemente a nota técnica conjunta entre os Ministérios da Saúde, da Educação e do Desenvolvimento Social e Combate à Fome, publicada em maio de 2013, que 
estabelece o aprofundamento da gestão intersetorial, firmando estratégias conjuntas para garantir a ampliação de acesso a direitos sociais de educação e saúde às crianças e adolescentes em situação de pobreza e extrema pobreza (beneficiárias do Programa Bolsa Família) no âmbito do PSE e do Programa Mais Educação.

A adesão ao programa deve ser realizada em sistema on-line do Ministério da Saúde e o planejamento do programa deve ser contemplado no Projeto Político Pedagógico da escola, considerando a competência política executiva dos estados e municípios, a diversidade sociocultural das diferentes regiões do país e a autonomia dos educadores e das equipes pedagógicas (BRASIL, 2011). São seis etapas a cumprir: i) cadastro dos Secretários de Saúde e Educação e representantes do Grupo de Trabalho Intersetorial; ii) escolha das escolas e dos níveis de ensino; iii) vinculação das equipes de Atenção Básica às escolas; iv) apresentação das ações essenciais e escolha das ações optativas; v) visualização de metas e pactuação dos componentes; e vi) visualização e impressão do Termo de Compromisso (BRASIL, 2011).

A escolha das escolas está pautada a um grupo de escolas denominadas prioritárias. Para que o Município possa avançar nas etapas de adesão, pelo menos 50\% do total de estabelecimentos (escolas) selecionados devem pertencer a esse grupo e pelo menos uma creche deve ser escolhida; em casos em que não há creches no Município, deve ser selecionada no mínimo uma pré-escola. Compõem o grupo de escolas prioritárias: as creches e pré-escolas públicas e conveniadas do Município; as escolas do campo; as escolas participantes do Programa Saúde na Escola do Programa Mais Educação no último ano; escolas que tiveram adolescentes em medidas socioeducativas matriculados no último ano; e escolas que tenham dentre os educandos matriculados, pelo menos $50 \%$ pertencentes a famílias beneficiárias do Programa Bolsa Família.

A institucionalização do PSE é fator agregador para solidificar a Escola e a Unidade Básica de Saúde como espaços de convivência social que possibilitem o estabelecimento de relações favoráveis à Promoção da Saúde baseadas na garantia de direitos fundamentados nos princípios da intersetorialidade, territorialidade e integralidade (BRASIL, 2012; BRASIL, 2014a). O PSE prevê o desenvolvimento de ações em cinco componentes (Quadro 1) através do pacto de integração entre os profissionais da educação e da saúde (BRASIL, 2007a). 
Quadro 1. Descrição dos componentes e eixos de ações presentes na normativa nacional do Programa Saúde na Escola (BRASIL, 2007a).

\begin{tabular}{|c|c|}
\hline COMPONENTES & EIXOS DE AÇÕES \\
\hline $\begin{array}{l}\text { I. Avaliação clínica e } \\
\text { psicossocial }\end{array}$ & $\begin{array}{l}\text { - Avaliação clínica e psicossocial desenvolvidas pelos } \\
\text { profissionais das equipes da Saúde da Família pelo menos uma } \\
\text { vez ao ano, preferencialmente no início dos períodos letivos. }\end{array}$ \\
\hline $\begin{array}{l}\text { II. Ações de promoção da } \\
\text { saúde e prevenção de } \\
\text { doenças e agravos. }\end{array}$ & $\begin{array}{l}\text { - Elaboração de plano de ação em saúde a ser incluído no } \\
\text { Projeto Político Pedagógico. } \\
\text { - Ações de promoção da alimentação saudável. } \\
\text { - Ações de promoção da atividade física. } \\
\text { - Educação para a saúde sexual e reprodutiva. } \\
\text { - Prevenção do uso de álcool, tabaco e outras drogas. } \\
\text { - Promoção da cultura de paz e prevenção de violências e } \\
\text { acidentes. }\end{array}$ \\
\hline $\begin{array}{l}\text { III. Educação permanente e } \\
\text { capacitação de profissionais } \\
\text { da educação e saúde e de } \\
\text { jovens para o PSE. }\end{array}$ & $\begin{array}{l}\text { - Capacitação de jovens, professores e profissionais da área da } \\
\text { educação e da saúde (de forma presencial e a distância). }\end{array}$ \\
\hline $\begin{array}{l}\text { IV. Monitoramento e } \\
\text { avaliação da saúde dos } \\
\text { estudantes. }\end{array}$ & $\begin{array}{l}\text { - Realização periódica de inquéritos e pesquisas nacionais e } \\
\text { regionais sobre fatores de risco e proteção à saúde dos } \\
\text { estudantes. }\end{array}$ \\
\hline $\begin{array}{l}\text { V. Monitoramento e } \\
\text { avaliação do PSE. }\end{array}$ & $\begin{array}{l}\text { - Monitoramento e avaliação do PSE, realizados por comissão } \\
\text { intersetorial constituída em ato conjunto dos ministros de } \\
\text { estado da saúde e da educação. A ideia é avaliar } \\
\text { sistematicamente e periodicamente o PSE. }\end{array}$ \\
\hline
\end{tabular}

As ações pactuadas são divididas em essenciais (ações que contam como alcance de meta) e optativas (ações que ficam a critério das equipes saúde e educação), ou seja, os atores tem autonomia para escolher se desejam realizar a ação ou não. Além disso, é previsto a realização da Semana de Saúde na Escola, um evento anual que possibilita maior visibilidade e reconhecimento das ações planejadas e executadas no âmbito do programa, além de mobilizar e envolver a comunidade no território pactuado. O objetivo principal da semana saúde na escola é dar início a uma mobilização temática prioritária de saúde, que deverá ser trabalhada ao longo do ano letivo nas escolas (BRASIL, 2015).

Destacamos a presença das atividades físicas como parte do conjunto de ações a serem desenvolvidas no PSE, incluídas no componente de Promoção da Saúde e prevenção de doenças e agravos (BRASIL, 2015). Segundo informações no site do Departamento de Atenção Básica, que gerencia pela área da saúde o PSE, as práticas corporais e atividades 
físicas estiveram presentes (direta ou indiretamente) nos temas da Semana de Saúde na Escola dos últimos quatro anos (BRASIL, 2014b):

- 2012- Prevenção à Obesidade na Infância e na Adolescência.

- 2013- Saúde Ocular e Prevenção da Obesidade na Infância e Adolescência.

- 2014- Práticas Corporais, Atividade Física e Lazer na perspectiva da Cultura de Paz e Direitos Humanos.

- 2015- Alimentação Saudável, cabendo também a realização de ações de práticas corporais e atividades físicas.

- 2016- Zica Zero.

\subsection{AS PRÁTICAS CORPORAIS E ATIVIDADES FÍSICAS COMO ELEMENTOS DE PROMOÇÃO DA SAÚDE}

A relação das práticas corporais e atividades físicas com a Promoção da Saúde estão associadas às concepções vigentes de educação física e de saúde em cada época (SOARES et $a l .$, 1992). O corpo em movimento é uma expressão fundamental da vida e os exercícios e práticas físicas tem uma relação histórica com a saúde - de forma bastante explicita na préhistória e em civilizações antigas, quando os homens precisavam lutar, fugir e caçar para sobreviver; e continuam sendo parte elementar da maioria dos trabalhos e dos meios de deslocamento até bem recentemente. Além disso, manter o corpo em movimento - na forma de esportes de competição ou espetáculo ou de exercícios físicos sistematizados e planejados - passa a ter finalidades higiênicas, terapêuticas, estéticas e de preparação militar; além das práticas corporais com fortes especificidades tradicionais; representando um aspecto importante do prazer e da cultura de um povo (NOGUEIRA, 2014).

No entanto, a Educação Física enquanto campo acadêmico nasce no Brasil em meados do século XX, visando formar professores para atuar predominantemente na escola. $\mathrm{Na}$ época até então denominada de ginástica, era centrada na ideia e importação de modelos europeus com finalidades de eugenização e higienização dos corpos, e construção de corpos sadios, a partir de uma perspectiva de raça onde o corpo ideal era o corpo branco (CASTELlANI FILHO, 1999). Centrada nos modelos tecnicista, militarista e médicohigienista, a Educação Física era vista como uma atividade exclusivamente prática que caracterizava o professor-instrutor e o aluno-recruta.

Nesse período, a formação profissional foi sustentada simplesmente nas atividades práticas. A instituição médica, através de uma ação baseada nos princípios da medicina social com função higiênica, adentra na reorganização dos padrões de conduta física, moral e 
intelectual, reforçando a educação do corpo tendo como meta a constituição de um físico saudável e equilibrado organicamente, menos suscetível às doenças (ARAUJO, 2014). Nessa perspectiva, a Educação Física e sua técnica calistênica se torna um valioso instrumento de ação e intervenção na realidade educacional e social (SOARES, 1992).

Posteriormente, após o término da Segunda Guerra Mundial, o modelo americano de organização desportiva, com seu caráter competitivo, passa a ser largamente difundido, inaugurando novos saberes, práticas e posturas para os profissionais da área. Tem inicio a tendência pedagógica do esportivismo, que desde então se tornou hegemônico na prática pedagógica da Educação Física escolar (CASTELLANI FILHO, 1999). Em meados de 1970 surge a Psicomotricidade, uma tendência que privilegia os aspectos metodológicos e se respalda em experiências pedagógicas com exercícios físicos realizados para corrigir distúrbios em crianças com dificuldades de adaptação social e escolar, centrando-se no desenvolvimento das condutas motoras como lateralidade, coordenação, percepção sonora, tátil e visual e equilíbrio (BRACHT, 1999).

No inicio da década de 1980, os lampejos do processo de redemocratização e da possibilidade de repensar a sociedade brasileira em vários campos da vida social, entre eles o cenário da educação e da saúde, representam um marco na história da Educação Física. Os chamados movimentos renovadores, influenciados pelas Ciências Sociais e Humanas promovem rupturas paradigmáticas no campo, e permitem que se reflita sobre os papéis da Educação Física, seus conhecimentos específicos e seus objetos de estudo e prática (CASTELLANI FILHO, 1999).

Ao mesmo tempo, a ciência hegemônica baseada fortemente nos estudos epidemiológicos aponta o aumento do sedentarismo como fator de risco no processo de adoecimento moderno (transição epidemiológica), marcado pela pandemia de doenças crônicas não transmissíveis (OPAS, 2005; CARVALHO, 2008). As academias, suas diferentes modalidades de exercícios e a visão da aptidão física (fitness) passam a ser amplamente divulgadas no Brasil como essenciais à saúde, numa perspectiva biomédica, individual e de consumo (COSTA, 2006). Aqui a ênfase dada para as atividades físicas na promoção da saúde responsabiliza o indivíduo por suas escolhas e hábitos de vida, deixando obscuros os diversos determinantes e condicionantes sociais, econômicos, culturais, ambientais e políticos dessa relação (FERREIRA, 2001; NOGUEIRA, 2014a).

Esses dois movimentos contraditórios conceitualmente, o escolar e o fitness, exacerbam os embates epistemológicos e as disputas político-ideológicas entre os saberes sociais e biológicos tanto no plano teórico quanto na práxis do campo (LIMA, 2000). É a partir de então que se iniciam, de forma sistemática, as reflexões epistemológicas da 
Educação Física. A definição do seu objeto de estudo e prática se relaciona com a função ou papel social a ela atribuído, definindo assim, o tipo de conhecimento buscado para a sua fundamentação (BRACHT, 1999).

Nesse sentido, surge um intenso debate tautológico, onde várias denominações, conceituações e classificações são propostas para se analisar o mesmo fenômeno, a partir de uma confusão entre os objetivos e a natureza do termo utilizado (LAZZAROTTI FILHO; SILVA; MARCARENHAS, 2014; LIMA, 2000). Termos como exercício, esporte, atividade física, ginástica, cultura corporal, movimento humano, prática corporal, motricidade, educação física e outros (BRASIL, 2004) circulam em espaços e discursos distintos, ora como sinônimos, ora marcados por algumas especificidades que os afastam, em um movimento permanente entre senso comum e conceitos científicos (BRACHT, 2000; BETTI et al., 2014).

As disputas político-ideológicas do campo $^{2}$ são exacerbadas a partir da inserção da Educação Física como profissão da grande área da saúde (BRASIL, 1997; RIGO; RIBEIRO; HALLAL， 2011; LAZZAROTTI FILHO; SILVA; MARCARENHAS， 2014;) e da aproximação de algumas áreas de saber da Educação Física com o campo da Saúde Coletiva e das iniciativas de Promoção da Saúde (NOGUEIRA; BOSI, 2016). As indefinições epistemológicas se tornam um desafio a mais na abordagem de tais temas principalmente no que diz respeito ao processo de produção e divulgação do conhecimento de forma intersetorial (LAZZAROTTI FILHO et. al., 2010). Exemplos são o uso conjunto, separado por uma “ / ”, dos termos práticas corporais / atividades físicas na própria PNPS (BRASIL, 2006; BRASIL, 2014a) e nos documentos que norteiam o PSE (BRASIL, 2007a). Não há clareza se essa opção visa indicar uma semelhança semântica ou abarcar duas concepções distintas da práxis em Educação Física.

Conforme abordado anteriormente, a possibilidade de confusões conceituais relativas ao conceito de Promoção da Saúde reforça a necessidade de consensos mínimos em torno de conceitos chave que permitam o diálogo e a consequente produção acadêmica sobre a temática das práticas corporais e atividades físicas na Promoção da Saúde. Sem o intuito de sermos concludentes, apresentamos algumas definições basilares ao campo da Educação Física para que possamos avançar nessa compreensão.

Ao adotarmos os termos "atividade física" ou "exercício físico" destacamos o papel da Educação Física no desenvolvimento físico-motor e da aptidão física. Os termos "movimento humano", "movimento corporal", ou "motricidade humana" ressaltam a

${ }^{2}$ Concordando com Bourdieu (1983) o conceito de campo se refere ao espaço de luta concorrencial no qual o que está em jogo são os monopólios da autoridade e da competência científica socialmente outorgadas. Disputas epistemológicas são intrinsecamente políticas entre estruturas conceituais operantes tanto no plano conceitual quanto na práxis. 
importância do movimento para o desenvolvimento integral, em especial relacionado à cognição e ao domínio afetivo-social. Por fim, o uso dos termos "cultura corporal”, ou “prática corporal" visa evidenciar que o objeto de uma prática pedagógica é uma construção, não uma dimensão inerte da realidade. O movimentar-se é uma forma de comunicação, constituinte e construtora de cultura. O que qualifica o movimento como humano é o sentido/significado do mover-se, mediados simbolicamente e expostos no plano da cultura (ARAÚJO, 2014).

Cabe apontar que as duas primeiras construções a respeito do objeto da Educação Física (biologia e psicologia do desenvolvimento) permitem ver o objeto não como construção social e histórica e, sim, como elemento natural e universal, portanto, não histórico, neutro politica e ideologicamente, características que marcam, também, a concepção de ciência onde vão sustentar suas propostas (BRACHT, 2000). Essa é a concepção historicamente hegemônica no campo da Educação Física, que busca promover a aptidão física e a saúde expressas pela capacidade de trabalho e/ou de rendimento individual, adotando primordialmente a concepção anátomo-fisiológica de corpo a ser desenvolvido numa perspectiva técnico-desportiva (BETTI et al., 2004).

Assim, as intercessões entre as práticas corporais e atividades físicas com o movimento da Promoção da Saúde ocorrem permeadas de diferentes entendimentos sobre os termos tanto nos documentos institucionais quanto nas práticas em serviço (SILVA; BAPTISTA, 2014; NOGUEIRA; BOSI, 2016). Ao atrelar as práticas corporais e atividades físicas a hábitos e comportamentos saudáveis e ao misturar as ações de promoção da saúde com a prevenção de doenças, os documentos reforçam as confusões epistemológicas e dificultam a identificação do enfoque que pretendem disseminar (BRASIL 2006; 2007; 2014).

A despeito das práticas corporais no contexto da Promoção da Saúde representarem um novo horizonte de práxis que vão além da transmissão de conhecimentos e de atitudes, os profissionais da saúde, professores de educação física inclusive, em geral concebem as atividades físicas como promotoras de saúde em um modelo individual, comportamental e atrelado ao conceito de aptidão física, de submissão e vitimização do corpo, não sendo capazes de colocar em prática as ações de Promoção da Saúde de forma ampliada e na perspectiva dos Determinantes Sociais da Saúde (LUZ, 2007; CARVALHO, 2008).

Sendo a Promoção da Saúde um elemento redirecionador das políticas e programas em saúde há a necessidade de sistematizar, em conformidade com os princípios do SUS e do próprio movimento internacional de Promoção da Saúde, propostas que provoquem ou reforcem o desenvolvimento de práticas corporais articuladas com os mais diferentes setores e com a participação social (BRASIL, 2006). Essas ações devem contribuir para a favorecer o 
empoderamento e a equidade no acesso e na produção do cuidado e de modos de vida saudáveis, incentivando a melhoria dos espaços públicos, considerando a cultura local, e incorporando brincadeiras, jogos, danças e lutas populares, dentre outras práticas para a melhoria da qualidade de vida da população (LAZZAROTTI FILHO et. al., 2010; OPAS, 1986).

Essas novas formas de conceber e agir em saúde se tornam ainda mais relevantes diante do contexto histórico, social, político e econômico das sociedades pós-modernas. Problemas contemporâneos como as iniquidades sociais refletidas na violência e poluição urbanas, o bullying nas escolas e a valorização social da atividade física impulsionada pelo mercado e pela mídia a partir de questões como estética, aptidão e rendimento físicos, dentre outros, são questões que o Campo da Educação Física precisa encarar, refletir e apontar caminhos para contribuir com a melhoria dessas grandes questões sociais em saúde (NOGUEIRA, 2014).

O novo pensar e agir em saúde origina novos modelos de atenção em saúde. As novas tendências exigem um olhar que extrapole os aspectos biológicos e tenha o sujeito indivíduo ou seu coletivo - como foco das ações, e o reconhecimento do limite da ação uniprofissional no ato de cuidar; implicando na readequação do modo de intervir dos profissionais da área (ANJOS; DUARTE, 2009).

No entanto, ainda são apresentadas limitações na formação em Educação Física uma vez que os profissionais da área se percebem como "agentes" promotores de saúde numa perspectiva prescritiva, comportamental e biomédica (NOGUEIRA, 2014). Parte do problema reside na dificuldade de profissionais e acadêmicos em internalizar a visão ampliada de saúde que perpassa por reflexões sobre a desigualdade social, as questões socioeconômicas e o olhar para as relações de poder entre os sujeitos, grupos sociais, instituições e as esferas da economia, política e cultura (PALMA, 2001). Essas dificuldades mantém relação com questões de formação, de crenças, de epistemologias e outros aspectos relativos ao campo da Educação Física (NOGUEIRA, 2014) que se refletem no cotidiano da prática profissional.

Considerando a Educação Física como área do saber que possui como objeto de estudo a cultura corporal, reconhecemos o papel estratégico que seus profissionais possuem nos processos de educação e da Promoção da Saúde junto à população, especialmente no contexto escolar. Não obstante, a legitimidade da Educação Física na escola passa por um processo de transformação denominado "Entre o não mais" e o "Ainda não", que consiste em colocá-la, por um lado, diante do abandono de um discurso centrado no "exercitar-se para..." e, de outro, diante das dificuldades encontradas na construção e efetivação de um novo modo de legitimação (GONZÁLEZ; FENSTERSEIFER, 2010). 
A prática pedagógica da Educação Física escolar precisa superar a perspectiva meramente prática da atividade física e passar a assumir seu papel social de construção de cidadania. Conforme expresso nos Parâmetros Curriculares Nacionais, a área da Educação Física é referenciada como mais uma possibilidade de relacionar os temas da saúde e sociedade em um contexto de busca pela democratização, humanização e diversificação da prática pedagógica ampliando a visão biológica para um trabalho que incorpore as dimensões afetivas, cognitivas e socioculturais dos sujeitos (CARVALHO, 2012a).

Nesse sentido, é importante uma reflexão no âmbito cientifico-acadêmico e de formação para uma análise e compreensão das relações de aproximações do objeto de estudo da Educação Física com a Promoção da Saúde em um contexto ampliado, onde sejam levados em consideração seus princípios norteadores. Por exemplo, o principio do empoderamento, que subsidia potencialmente para que a população identifique, faça escolhas, trace metas e elabore estratégias para superar as dificuldades concretas para a realização de sua prática corporal e reflita a respeito da determinação social vinculada à realidade em que se vive (FIALHO et al., 2014). Ou ainda que atue nos determinantes e condicionantes da saúde e na participação social, elaborando alternativas às práticas educativas que se restringem à intervenção sobre os hábitos e estilos de vida individuais (CARVALHO; GASTALDO, 2008). Ao possibilitar que a comunidade escolar influencie e construa seus entornos e assuma o controle de suas vidas a Educação Física passa a ser difusora de valores e ações que efetivamente contribuem com o ideário da Escola Promotora de Saúde (ROCHA; MARCELO; PEREIRA, 2002). 


\section{OBJETIVOS}

\subsection{OBJETIVO GERAL}

Analisar as percepções sobre o PSE, a Promoção da Saúde e a relação desses com as Práticas Corporais ou Atividades Físicas, a partir da visão de professores de Educação Física de escolas que aderiram ao PSE no DF durante os anos de 2014 e 2015.

\subsection{OBJETIVOS ESPECÍFICOS}

- Caracterizar a participação dos professores de Educação Física no PSE.

- Determinar o conhecimento desses professores sobre o PSE.

- Investigar as percepções sobre Promoção da Saúde.

- Analisar as percepções sobre a relação das práticas corporais e atividades físicas com a Promoção da Saúde.

- Identificar a produção cientifica sobre o PSE. 


\section{PROCEDIMENTOS METODOLÓGICOS}

Para alcançar os objetivos propostos, o desenvolvimento do presente estudo passou por três etapas complementares (Quadro 2). Cabe destacar que os processos exploratórios e de reflexão perpassam todo o período do estudo e que a opção de representação em um esquema por etapas se destina à organização descritiva na redação da dissertação. As etapas realizadas na pesquisa não aconteceram de forma linear e sim em um processo de circularidade na pesquisa (FLICK, 2009). As etapas exploratórias e de trabalho de campo serão descritas em detalhes a seguir. A etapa reflexiva compõe o capítulo de discussão do presente trabalho.

Quadro 2. Etapas do estudo desenvolvido com professores de Educação Física que atuam em escolas que aderiam ao PSE na vigência 2014 e 2015.

\begin{tabular}{|c|c|c|c|}
\hline Etapa & $\begin{array}{l}\text { Atividades } \\
\text { realizadas }\end{array}$ & $\begin{array}{l}\text { Estratégias de } \\
\text { investigação }\end{array}$ & Objetivos Específicos \\
\hline \multirow[b]{2}{*}{ Exploratória } & $\begin{array}{c}\text { Aprofundamento } \\
\text { no tema. }\end{array}$ & $\begin{array}{l}\text { Revisão da literatura com } \\
\text { utilização das técnicas de } \\
\text { resenha e fichamento. }\end{array}$ & $\begin{array}{l}\text { Identificar referenciais } \\
\text { teóricos e instrumentos que se } \\
\text { adequem à pesquisa. }\end{array}$ \\
\hline & $\begin{array}{c}\text { Imersão no } \\
\text { contexto e } \\
\text { planejamento da } \\
\text { pesquisa. }\end{array}$ & $\begin{array}{l}\text { Imersão no contexto com } \\
\text { registros em diário de } \\
\text { campo. }\end{array}$ & $\begin{array}{l}\text { Identificar variáveis e } \\
\text { informações relevantes } \\
\text { referentes ao contexto; e os } \\
\text { sujeitos da pesquisa. }\end{array}$ \\
\hline $\begin{array}{l}\text { Trabalho de } \\
\text { campo }\end{array}$ & $\begin{array}{c}\text { Realização de } \\
\text { entrevistas } \\
\text { semiestruturadas. }\end{array}$ & $\begin{array}{l}\text { Análise de conteúdo e } \\
\text { categorização }\end{array}$ & $\begin{array}{l}\text { Conhecer a percepção dos } \\
\text { professores de Educação } \\
\text { Física sobre: o PSE; a } \\
\text { Promoção da Saúde; as } \\
\text { práticas corporais e atividades } \\
\text { físicas em relação à Promoção } \\
\text { da Saúde. }\end{array}$ \\
\hline $\begin{array}{l}\text { Reflexivo- } \\
\text { Analítico }\end{array}$ & $\begin{array}{l}\text { Discussão do } \\
\text { tema. }\end{array}$ & $\begin{array}{c}\text { Uso dos referenciais } \\
\text { teóricos de Promoção da } \\
\text { Saúde e aproximações com } \\
\text { o Paradigma da } \\
\text { complexidade. }\end{array}$ & $\begin{array}{c}\text { Reflexões a partir do discurso } \\
\text { dos professores da Educação } \\
\text { Física. }\end{array}$ \\
\hline
\end{tabular}

\subsection{APROFUNDAMENTO NO TEMA}

Como parte inicial da etapa exploratória foi realizada uma revisão de literatura que, além de permitir a identificação de referenciais teóricos pertinentes e proporcionar maior familiarização com o problema de pesquisa, subsidiou toda a discussão dos resultados encontrados no presente estudo. 
A busca dos estudos foi realizada nas bases de dados PubMed, Medline, Lilacs (Biblioteca Virtual em Saúde), Scielo, Google Scholar, Periódico Capes e na Biblioteca Digital Brasileira de Teses e Dissertações do Instituto Brasileiro de Informação em Ciência e Tecnologia disponíveis na Internet. Os descritores utilizados, em diferentes combinações, foram: "promoção de saúde, saúde, programa saúde na escola, escola promotora de saúde, percepção, professor, educação física, atividades físicas, práticas corporais” em português e "health promotion, health, school health program, health promoting schools, perception, teacher, physical education, physical activity and bodily practices" em inglês. As referências bibliográficas dos estudos encontrados foram pesquisadas a fim de localizar mais trabalhos sobre o tema. Em adição, documentos disponíveis em sites institucionais (Ministérios da Saúde e Educação) e material de literatura cinza (gray literature) disponíveis na Internet relevantes à temática também foram consultados.

As buscas nas bases de dados retornaram 1530 resultados no Google Scholar e 878 no LILACS (Literatura Latino-Americana e do Caribe em Ciências da Saúde); o elevado número de resultados se deveu à busca ser redirecionada para descritores mais amplos tais como "saúde" e "escola". Optou-se então por restringir as buscas aos artigos científicos publicados em periódicos indexados e teses e dissertações que apresentassem preferencialmente o descritor "Programa Saúde na Escola" no título, no resumo ou nas palavras-chave, delimitando-a temporalmente entre 2007, ano de criação do programa, e 2016.

Após a limpeza de trabalhos que apareceram duplicados em mais de uma base de dados e uma leitura flutuante dos resumos para identificar a pertinência à temática (estudos que abordaram o PSE de forma secundária ou superficial - apenas citam o programa, mas não o estudam - foram excluídos), foram identificados 32 artigos científicos, 15 dissertações e 3 teses que versam sobre o PSE.

O Quadro 3 apresenta o panorama dos artigos científicos e o Quadro 4 apresenta o panorama das dissertações e teses que se referem ao PSE incluindo informações sobre: autores e ano da publicação, região de realização, tema e metodologia utilizada nas pesquisas. 
Quadro 3. Panorama dos artigos científicos publicados entre 2007 e 2016 que se referem ao Programa Saúde na Escola (PSE).

\begin{tabular}{|c|c|c|c|}
\hline Referência & $\mathbf{U F}$ & Tema & Metodologia adotada \\
\hline Cord et al.(2015) & $\mathrm{SC}$ & $\begin{array}{l}\text { Dificuldades de aprendizagem, patologização e medicalização do } \\
\text { fracasso escolar. }\end{array}$ & Qualitativo com entrevista semiestruturada. \\
\hline Köptcke et al. (2015) & DF & Implementação do Programa Saúde na Escola. & Qualitativo com entrevista. \\
\hline Leite et al. (2015) & $\mathrm{CE}$ & Percepções de professores sobre o PSE. & Qualitativo com entrevista semiestruturada. \\
\hline Magalhães (2015) & RJ & Implementação de ações intersetoriais. & Qualitativo com entrevista. \\
\hline Silva et al. (2015) & MG & Políticas públicas na promoção à saúde de adolescentes. & Qualitativo com entrevista. \\
\hline Ferreira et al. (2014) & NA & Intersetorialidade no PSE. & Qualitativo com questionário eletrônico. \\
\hline Silva et al. (2014) & $\mathrm{PE}$ & Promoção da saúde no PSE e a inserção da enfermagem. & Qualitativo com entrevista. \\
\hline Jacóe et al. (2013) & MG & Implantação do PSE. & Qualitativo com entrevista. \\
\hline Penso et al. (2013) & $\mathrm{DF}$ & $\begin{array}{l}\text { Percepções dos profissionais que trabalham com adolescentes na } \\
\text { atenção primária à saúde. }\end{array}$ & Qualitativo com entrevista semiestruturada. \\
\hline $\begin{array}{l}\text { Albuquerque e Menezes } \\
\text { (2010) }\end{array}$ & $\mathrm{PE}$ & Educação alimentar na escola. & $\begin{array}{l}\text { Qualitativo com entrevista semiestruturada e } \\
\text { observação. }\end{array}$ \\
\hline Queiroz et al.(2011) & $\mathrm{CE}$ & Cuidado ao adolescente e integralidade na atenção primária. & Qualitativo com entrevista semiestruturada. \\
\hline Machado et al. (2015) & NA & Ações desenvolvidas pelas Equipes de Saúde da Família no PSE. & Quantitativo com questionários. \\
\hline Pereira et al. (2015) & MG & Aptidão física de escolares. & Quantitativo com testes motores. \\
\hline Honório e Hadler (2014) & GO & Obesidade infantil. & Quantitativo com questionário estruturado. \\
\hline Izidoro et al. (2014) & MG & Estado nutricional e desempenho escolar. & $\begin{array}{l}\text { Quantitativo com avaliação do peso e estatura, e } \\
\text { provas de leitura, escrita e aritmética. }\end{array}$ \\
\hline Ramires et al. (2014) & $\mathrm{AL}$ & Estado nutricional de escolares. & Quantitativo com avaliação antropométrica. \\
\hline Assis et al. (2013) & RJ & Conhecimentos e práticas educativas sobre dengue. & Qualitativo com entrevista semiestruturada. \\
\hline
\end{tabular}


Continuação Quadro 3.

\begin{tabular}{|c|c|c|c|}
\hline Referência & $\mathbf{U F}$ & Tema & Metodologia adotada \\
\hline Brito e Oliveira (2013) & $\mathrm{PE}$ & Bullying e autoestima de escolares. & Quantitativo com questionário estruturado. \\
\hline Giacomozzi et al. (2012) & $\mathrm{SC}$ & Drogas e vulnerabilidades de estudantes. & Quantitativo com questionário estruturado. \\
\hline Teixeira et al. (2014) & NA & Avaliação de práticas de promoção da saúde. & Quantitativo com questionários \\
\hline Prado e Lima (2013) & $\mathrm{PE}$ & Saúde ocular e o trabalho preventivos de enfermeiros. & Revisão de literatura. \\
\hline Tabosa et al. (2013) & $\mathrm{CE}$ & Gestão da informação no PSE. & Revisão de literatura. \\
\hline Teles (2014) & NA & Nutrição e o processo de medicalização. & Revisão de literatura. \\
\hline Cavalcanti et al. (2015). & NA & Inconsistências na concepção de promoção da saúde no PSE. & Revisão bibliográfica e documental. \\
\hline Oliveira et al. (2015) & ES & Educação Física e o PSE. & $\begin{array}{l}\text { Estudo documental e pesquisa-ação com } \\
\text { observações e entrevista semiestruturada. }\end{array}$ \\
\hline $\begin{array}{l}\text { Christmann e Pavão } \\
\text { (2015) }\end{array}$ & NA & Articulação entre saúde e educação por meio do PSE. & Estudo documental. \\
\hline Assis e Jorge (2014) & NA & Doenças negligenciadas e a promoção da saúde. & Estudo documental. \\
\hline Dias et al. (2014) & $\mathrm{CE}$ & Análise nos documentos oficiais do PSE. & Estudo documental. \\
\hline Ferreira et al. (2012) & NA & Diplomas Normativos do Programa Saúde na Escola. & Estudo documental. \\
\hline Schuler et al. (2015) & $\mathrm{RS}$ & Protagonismo juvenil no PSE. & Estudo de caso. \\
\hline Teive e Abud (2014) & $\mathrm{SC}$ & Reflexões e críticas a respeito do PSE. & Estudo de caso. \\
\hline Santiago et al. (2011) & $\mathrm{CE}$ & Implantação do PSE. & Relato de experiência com observações. \\
\hline
\end{tabular}

Legenda: UF, Unidade da Federação; SC: Santa Catarina; DF: Distrito Federal; CE: Ceará; RJ: Rio de Janeiro; MG: Minas Gerais; NA: Nacional; PE:

Pernambuco; GO: Goiás; AL: Alagoas; ES: Espirito Santo; RS: Rio Grande do Sul; 
Quadro 4. Panorama das teses e dissertações publicadas entre 2007 e 2016 que que se referem ao Programa Saúde na Escola (PSE).

\begin{tabular}{|c|c|c|c|}
\hline Referência & UF & Tema & Metodologia adotada \\
\hline Barbieri, 2014 & PR & Políticas públicas brasileiras de educação e saúde. & $\begin{array}{l}\text { Revisão bibliográfica e documental fundamentada no } \\
\text { método materialista-histórico. }\end{array}$ \\
\hline Silveira, 2014 & $\mathrm{RS}$ & $\begin{array}{l}\text { Análise do PSE nas perspectivas de estudos culturais, de } \\
\text { gênero e de Foucault. }\end{array}$ & $\begin{array}{l}\text { Pesquisa documental com análise de discurso na perspectiva } \\
\text { cultural. }\end{array}$ \\
\hline Cirqueira, 2014 & GO & $\begin{array}{l}\text { Perfil antropométrico, estilo de vida e comportamento sexual } \\
\text { de adolescentes. }\end{array}$ & Quantitativa com aplicação de questionário. \\
\hline Farias, 2014 & $\mathrm{PE}$ & Análise da intersetorialidade no PSE. & Qualitativa com entrevistas semiestruturadas. \\
\hline Brandão, 2014 & RJ & Estratégias de implementação do PSE. & Análise documental. \\
\hline Silva, 2013 & $\mathrm{CE}$ & Atuação de enfermeiros na prevenção de DST/Aids. & $\begin{array}{l}\text { Quanti-qualitativa com entrevista semiestruturada e } \\
\text { checklist. }\end{array}$ \\
\hline Silva, 2013 & GO & Conhecimentos e práticas sobre Promoção da Saúde. & Qualitativa com grupo focal. \\
\hline Vieira, 2013 & DF & Intersetorialidade no PSE. & $\begin{array}{l}\text { Quanti-qualitativa com triangulação de dados } \\
\text { (bibliográficos, documentais e de campo). }\end{array}$ \\
\hline Costa, 2013 & SE & Análise de políticas públicas de educação no Brasil. & Revisão bibliográfica com enfoque histórico dialético. \\
\hline Felix, 2013 & MG & $\begin{array}{l}\text { Integralidade e intersetorialidade no âmbito da saúde na } \\
\text { escola. }\end{array}$ & Qualitativa com entrevista. \\
\hline Tusset, 2012 & $\mathrm{DF}$ & Competências em PS no processo de implementação do PSE. & Qualitativa com entrevistas e análise documental. \\
\hline Paiva, 2012 & $\mathrm{CE}$ & Análise da implantação do PSE. & Qualitativa com entrevistas semiestruturadas. \\
\hline Gomes, 2012 & RJ & Desafios e possibilidades para a ação intersetorial. & Qualitativa com entrevistas semiestruturadas. \\
\hline Souza, 2012 & $\mathrm{PE}$ & Análise das ações de saúde e nutrição. & Qualitativa com entrevistas semiestruturadas. \\
\hline Uchôa, 2012 & $\mathrm{AM}$ & $\begin{array}{l}\text { Análise do PSE a partir da percepção dos agentes sociais } \\
\text { envolvidos. }\end{array}$ & $\begin{array}{l}\text { Qualitativa com entrevistas semiestruturadas e questionários } \\
\text { abertos. }\end{array}$ \\
\hline Cargnin, 2015 & $\mathrm{RS}$ & Problematização da relação saúde e educação no PSE & $\begin{array}{l}\text { Estudo documental e analítico com o referencial de } \\
\text { Foucault. }\end{array}$ \\
\hline
\end{tabular}


Continuação Quadro 4.

\begin{tabular}{|l|c|l|l|}
\hline Silva, 2014 & SP & Alimentação, nutrição e estado nutricional de escolares. & $\begin{array}{l}\text { Quantitativo longitudinal com formulário eletrônico e } \\
\text { avaliação de tendência do estado nutricional. }\end{array}$ \\
\hline Silva Junior, 2014 & MT & $\begin{array}{l}\text { Limites e possibilidades intersetoriais para o desenvolvimento } \\
\text { do autocuidado na escola. }\end{array}$ & Qualitativa com entrevistas semiestruturadas. \\
\hline
\end{tabular}

Legenda: UF, Unidade da Federação; PR: Paraná; RS: Rio Grande do Sul; GO: Goiás; PE: Pernambuco; RJ: Rio de Janeiro; CE: Ceará; DF: Distrito Federal; SE: Sergipe; MG: Minas Gerais; DF: Distrito Federal; CE: Ceará; RJ: Rio de Janeiro; PE: Pernambuco; AM: Amazonas; RS: Rio Grande do Sul; SP: São Paulo; MT: Mato Grosso. 


\subsection{IMERSÃO NO CONTEXTO}

Ainda como parte exploratória, a imersão da pesquisadora no contexto da pesquisa se iniciou através de contato com coordenadores do PSE no Distrito Federal (DF), sendo uma representante da Secretaria de Estado de Saúde e outra da Secretaria de Estado de Educação. Na primeira reunião agendada, em março de 2015, foi realizada uma apresentação geral sobre a temática e uma proposta de parceria e coparticipação para a realização da pesquisa. A partir de então, a pesquisadora passou a frequentar, por seis meses, as reuniões da gestão do PSE no DF adotando um olhar crítico quanto à realidade e registrando suas impressões e informações obtidas no diário de campo.

As informações coletadas a partir das reuniões e do acesso a documentos institucionais mostram que o PSE foi lançado oficialmente no DF em 2009, através da articulação entre um grupo técnico intersetorial com membros da Secretaria de Saúde e de Educação que, por meio de reuniões e oficinas realizadas no decorrer de 2008, definiram um plano de trabalho e um projeto final. Sua implantação no DF foi direcionada para contribuir com a ruptura do modelo tradicional de atenção assistencialista, biomédica e fragmentada, transformando-a numa atenção integral e intersetorial à saúde de crianças e adolescentes do ensino fundamental, o que se caracterizava como um desafio emergente (DISTRITO FEDERAL, 2009).

Foi elaborada uma minuta de portaria na qual se definiu as atividades a serem desenvolvidas, dentre as quais se destacam as atividades relacionadas à assistência, à Promoção da Saúde e prevenção de agravos tais como: avaliação clínica, nutricional, oftalmológica, otorrinolaringológica, psicossocial, saúde bucal e verificação da situação vacinal; promoção dos fatores de proteção relacionados com os estilos de vida da comunidade; educação em saúde mental, oral, sexual, reprodutiva, nutricional, desportiva e ambiental; e prevenção das doenças transmissíveis e do consumo de substâncias lícitas ou ilícitas prejudiciais à saúde (DISTRITO FEDERAL, 2009).

A partir de então, a quantidade de escolas e unidades de saúde que aderiram ao PSE no DF foi aumentando ano a ano (Quadro 5). Na vigência de 2014 e 2015 o DF possuía um total de 657 escolas e 226 unidades de saúde divididas em 14 Regionais na educação e 15 Regionais na saúde. 
Quadro 5. Quantitativo anual de instituições que aderiram ao Programa Saúde na Escola no Distrito Federal.

\begin{tabular}{|l|c|c|}
\hline ANO & QUANTIDADE DE ESCOLAS & $\begin{array}{c}\text { QUANTIDADE DE UNIDADES DE } \\
\text { SAÚDE }\end{array}$ \\
\hline $\mathbf{2 0 0 9}$ & 26 & 24 \\
\hline $\mathbf{2 0 1 0}$ & 87 & 24 \\
\hline $\mathbf{2 0 1 1}$ & 45 & 37 \\
\hline $\mathbf{2 0 1 2}$ & 61 & 52 \\
\hline $\mathbf{2 0 1 3}$ & 132 & 49 \\
\hline $\mathbf{2 0 1 4}$ e 2015 & 162 & 128 \\
\hline
\end{tabular}

Dados informados pela Secretaria de Saúde do Distrito Federal em 2015.

Cabe destacar que em 2014, o PSE-DF atingiu 98\% das prioridades de inserção elencadas pela área federal, contemplando número de escolas inseridas; inserção de creches; inserção de escolas das unidades de internação socioeducativas e escolas com mais de $50 \%$ de alunos matriculados no Programa Bolsa Família. As ações do programa no DF contam com a parceria ensino-serviço no contexto do Programa Nacional de Reorientação da Formação Profissional em Saúde e constitui uma agenda estratégica de integração dos cursos da área de saúde da Universidade de Brasília com o SUS, conforme as Diretrizes Curriculares Nacionais dos cursos de graduação em Saúde e a política de regionalização do ensino e atenção à saúde das Secretarias de Saúde e Educação do DF (DISTRITO FEDERAL, 2009; ROCHA; TUSSET, 2011).

Na vigência de 2014/2015, as atividades pactuadas para o PSE-DF foram: avaliação clínica voltada para avaliação antropométrica, verificação da situação vacinal, saúde ocular, saúde bucal, identificação de possíveis sinais relacionados às doenças negligenciadas, saúde auditiva (optativa), e desenvolvimento de linguagem (optativa). Promoção da saúde e prevenção de doenças voltada para segurança alimentar e alimentação saudável, saúde mental, promoção da cultura de paz e diretos humanos, prevenção nas escolas, educação sexual, saúde reprodutiva e prevenção de doenças sexualmente transmissíveis, prevenção ao uso de drogas, prevenção de acidentes (optativa), saúde ambiental (optativa) e práticas corporais e atividades físicas (optativa).

Um dos aspectos mais chamativos desse processo de imersão no contexto do PSE no DF foi descobrir que as atividades relacionadas às práticas corporais e atividades físicas eram tratadas como atividades optativas e eventos esporádicos, como por exemplo, ações na 
Semana de Saúde da Escola. Em 2015 a 4ª edição dessa semana de mobilização aconteceu no período de 27 a 30 de abril onde participamos realizando atividades de alongamento com escolares do ensino fundamental II ( $7^{\circ}$ e $8^{\circ}$ ano) em uma escola de Ensino Fundamental localizada no Plano Piloto.

Diante da pouca ênfase às ações do eixo práticas corporais e atividades físicas nas portarias e pactuações, coordenadores do PSE no DF foram consultados e contribuíram na identificação das regionais administrativas que mais realizavam ações do programa de forma contínua e estruturada. Informações colhidas nessa etapa permitiram a identificação de seis possíveis regionais (Taguatinga, Paranoá, Itapoã, Sobradinho II, Plano Piloto e Ceilândia). A seguir, os gerentes responsáveis por cada regional foram contatados para identificar escolas ou unidades de saúde e atores-chaves que realizavam ações do programa, com possibilidade de algumas serem do eixo práticas corporais e atividades físicas. Cabe destacar que não conseguimos estabelecer contato com a regional de Ceilândia pois na época a responsável pelo o PSE estava de férias e licença maternidade, e o programa estava em processo de mudança de endereço.

Essa etapa de imersão possibilitou a primeira caracterização do cenário de pesquisa; permitiu a realização de levantamentos e esclarecimentos a respeito das regionais administrativas, das escolas, dos sujeitos e das variáveis a serem estudadas; favoreceu o estabelecimento de vinculo entre a pesquisadora e os coordenadores locais; e facilitou a organização das visitas e entrevistas in loco.

\subsection{PLANEJAMENTO DO ESTUDO}

\subsubsection{Aspectos Éticos}

Com o termo de concordância das instituições coparticipantes (ANEXOS I e II) em mãos e o projeto de pesquisa delineado a partir das informações obtidas, demos entrada no Comitê de Ética em Pesquisas com Seres Humanos (CEPE) da Faculdade de Ciências da Saúde da Universidade de Brasília (UnB), seguindo a Resolução 466 de 2012, que regulamenta a pesquisa envolvendo seres humanos. O projeto foi aprovado pelo parecer FS/UnB (ANEXO III).

A participação na pesquisa foi livre e esclarecida em todas as etapas, formalizada mediante carta convite e assinatura do Termo de Consentimento Livre e Esclarecido (TCLE Apêndice A), onde constavam informações sobre: tema, objetivos e justificativa da pesquisa; 
participação voluntária, sigilosa, não invasiva e privada; sem custo ou risco físico ou emocional para o participante e a instituição à qual ele está vinculado; possibilidade de desistência a qualquer momento; e que a pesquisa e os procedimentos metodológicos da mesma foram respaldados pelo CEPE-UnB.

\subsubsection{Elaboração do Roteiro de Entrevista}

$\mathrm{O}$ roteiro de entrevista semiestruturada (Apêndice B) foi elaborado de forma a identificar o conhecimento e as percepções (sentidos, significados e conceitos) sobre os temas da Promoção da Saúde, do PSE, das práticas corporais e atividades físicas, e suas interrelações conforme a Figura 1 a seguir. Cabe destacar que o mesmo foi elaborado e analisado por três especialistas professoras doutoras a respeito da forma e conteúdo e testado em um estudo piloto para refinamento das perguntas e preparação da entrevistadora quanto aos procedimentos metodológicos de realização de entrevistas.

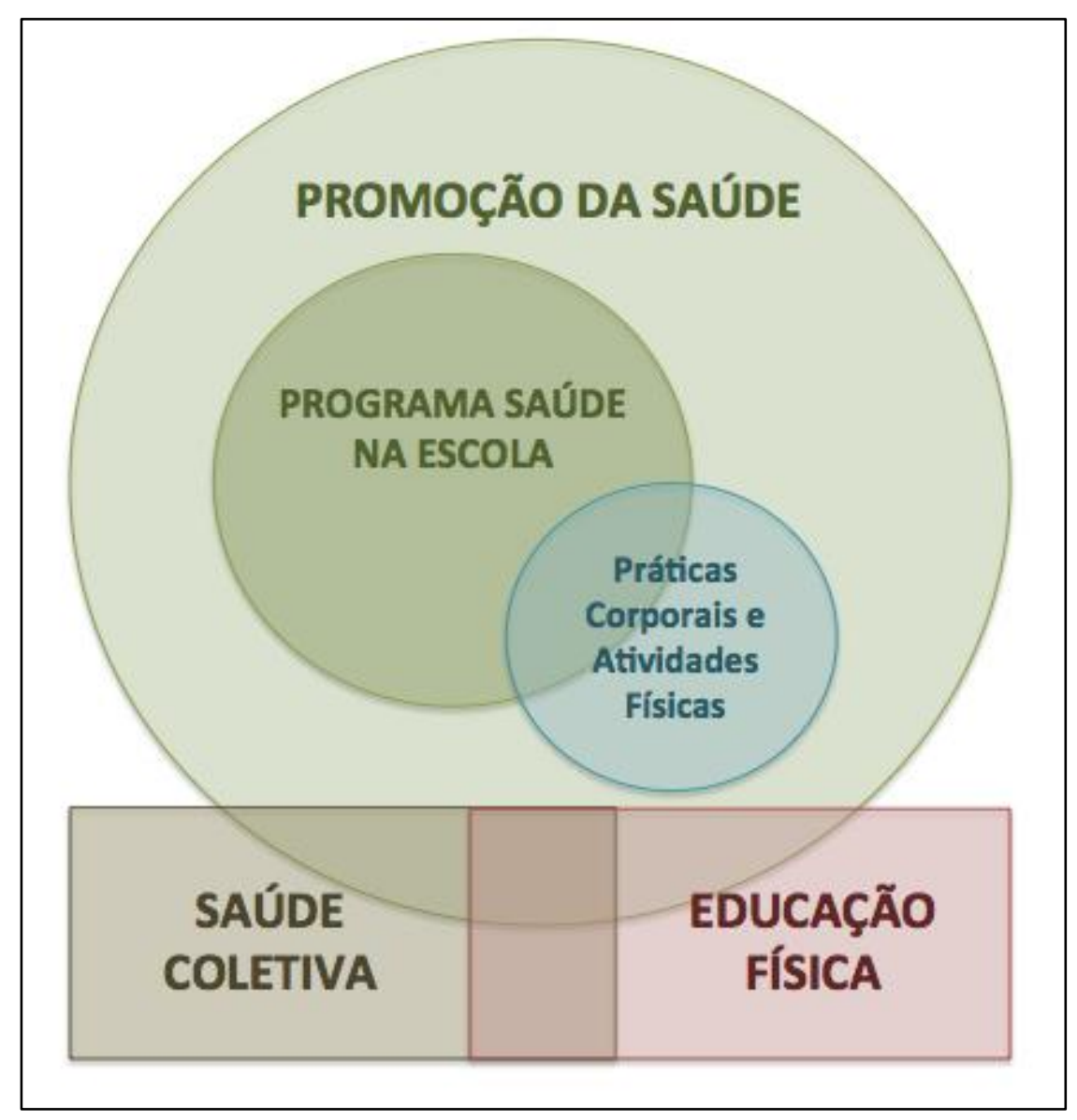

Figura 1. Esquema conceitual delimitador do estudo e norteador para a elaboração do roteiro de entrevista (elaborada pela autora). 


\subsubsection{Seleção dos participantes}

Inicialmente, a população da pesquisa seriam os profissionais que atuam no PSE do DF considerados atores-chave no desenvolvimento de ações do eixo das práticas corporais e atividades físicas. No entanto, no decorrer do processo de imersão no contexto foi ficando claro que, tanto nos documentos quanto nos relato dos coordenadores e gerentes do programa, não havia registros da realização dessas ações e consequentemente, não havia atores-chave no desenvolvimento desse eixo de ações.

A partir dos contatos com os coordenadores do PSE responsáveis pelas cinco regionais (Taguatinga, Paranoá, Itapoã, Sobradinho II e Plano Piloto) indicadas como destaque na realização de ações do programa buscamos mais uma vez indicação de escolas que poderiam desenvolver ações de práticas corporais e atividades físicas no PSE. Mais uma vez se confirmou que não havia experiências de destaque em relação ao eixo práticas corporais e atividades físicas.

Desta forma solicitamos indicação de escolas que poderíamos visitar para conhecer o desenvolvimento do PSE em cada regional e a população alvo da pesquisa passou a ser os professores de Educação Física que atuavam nessas escolas.

\subsection{TRABALHO DE CAMPO E REALIZAÇÃO DE ENTREVISTAS}

A partir dos contatos e das indicações fornecidas pelos coordenadores regionais agendamos visitas à seis escolas que aderiam ao PSE no DF (Quadro 6); os nomes completos das escolas não foram informados para garantir o direito ético ao anonimato dos participantes.

Quadro 6. Instituições escolares visitadas e suas respectivas Regionais Administrativas.

\begin{tabular}{|c|c|}
\hline Escolas / nível de ensino & Região Administrativa \\
\hline Centro de Ensino Fundamental 1 & Taguatinga \\
\hline Centro de educação 1 & Paranoá \\
\hline Centro de educação 1 & Itapoã \\
\hline Centro de Atenção Integral à Criança & Sobradinho II \\
\hline Centro de Ensino Fundamental 2 & Plano Piloto \\
\hline Centro de Ensino Fundamental 3 & \\
\hline
\end{tabular}

Ao visitar as escolas buscamos conhecer um pouco da realidade local, conversamos com os responsáveis pelo PSE e buscamos identificar a realização de ações relacionadas ao Programa. Mais uma vez foi confirmada a inexistência de ações de práticas corporais e 
atividades físicas como atividades do Programa. Após esse contato inicial, foi feita a apresentação da pesquisadora responsável para o professor de Educação Física e a explicação do motivo da visita à escola: realizar uma pesquisa para conhecer as práticas corporais e atividades físicas no PSE e suas relações com o tema da Promoção da Saúde na escola.

A seguir, foi feito o convite para uma conversa de aproximadamente 30 minutos sobre o tema da pesquisa, em qualquer momento que fosse conveniente ao professor. Todos os professores convidados aceitaram prontamente em participar da conversa (entrevista) e então a mesma foi agendada. No dia marcado, ao encontrar o professor buscou-se um local tranquilo para a conversa. Os locais das entrevistas se diversificaram de acordo com a acomodação de cada professor (a). A seguir a pesquisadora explicou algumas informações gerais sobre o tema e o processo da conversa na forma de entrevista e formalizou o convite à participação na pesquisa mediante apresentação e assinatura do TCLE.

As entrevistas seguiram o roteiro semiestruturado (Apêndice B) sobre os temas da Promoção da Saúde, do PSE e das práticas corporais e atividades físicas; tiveram duração aproximada de 20 minutos e foram gravadas através de um gravador de voz digital (SONY, IC Recorder, Quick Start Guide). Depois de gravadas e transcritas pela pesquisadora responsável, as entrevistas foram analisadas por meio da técnica de análise de conteúdo segundo Bardin (2007), de acordo com as seguintes etapas:

i. Pré-análise: leitura flutuante de todos os materiais para operacionalizar e sistematizar as ideias presentes no depoimento e a tomada de uma primeira decisão sobre quais deles efetivamente estão de acordo com os objetivos da pesquisa. Foi utilizada a técnica de colorir do editor de texto para organizar as unidades de análises (temas).

ii. Exploração: releitura cuidadosamente dos materiais e identificação das unidades de análise, elemento unitário de conteúdo a ser submetido posteriormente à classificação.

iii. Tratamento dos resultados e interpretação: agrupamento das unidades de análise de acordo com sua semelhança com o auxílio de planilhas eletrônicas. Em seguida, iniciou-se o processo de categorização, agrupando informações considerando a parte comum entre elas. A partir das sínteses coincidentes e divergentes e da interpretação inferencial as relações dos conteúdos foram estabelecidas.

A partir do referencial teórico, do desmembramento dos textos e do agrupamento analógico e o refinamento dos dados selecionados das falas dos entrevistados, tivemos como resultantes o agrupamento progressivo de três categorias iniciais, que resultaram na iminência das nove subcategorias e por fim, vários temas emergentes da fala dos professores. 


\section{RESULTADOS}

\subsection{CARACTERÍSTICAS DO CONTEXTO}

Participaram do estudo onze professores de Educação Física que atuavam em seis escolas de Ensino Fundamental da Rede Pública do DF que haviam aderido ao PSE na vigência de 2014 a 2015 (Quadro 7). A seguir apresentamos algumas características das Escolas e das Regiões Administrativas visitadas.

Quadro 7. Distribuição quantitativa de professores entrevistados por Regional Administrativa e Escolas.

\begin{tabular}{|c|c|c|}
\hline Região Administrativa & Escolas & Professores \\
\hline Taguatinga & 01 & 1 \\
\hline Paranoá & 01 & 1 \\
\hline Itapoã & 01 & 4 \\
\hline Sobradinho II & 01 & 3 \\
\hline Plano Piloto & 02 & $\mathbf{1 1}$ \\
\hline TOTAL & $\mathbf{0 6}$ & 1 \\
\hline
\end{tabular}

\section{Taguatinga}

A escola visitada em Taguatinga oferta o nível de ensino Fundamental (anos finais) e meio período. Tem uma excelente estrutura física com ginásio poliesportivo, recepção organizada na entrada da escola além de desenvolver diversas atividades, projetos e campanhas educativas propostos pela Secretaria de Educação e outros órgãos inclusive a Unidade Básica de Saúde parceira da escola. Sobre as ações do PSE as mesmas foram reduzidas nos anos de 2014 e 2015.

Taguatinga contempla estrutura de cidade desenvolvida, conta com 350 mil habitantes e atualmente é considerada o maior polo comercial do DF. A população idosa é maioria (21\%), e uma participação menor do grupo de zero a 14 anos (17\%). Quanto à escolaridade, a maior proporção de adultos possui o ensino fundamental incompleto ou o médio completo. Quanto à infraestrutura, os serviços de abastecimento de água e energia, e o esgotamento sanitário por rede estão próximos de uma cobertura completa (CODEPLAN, 2013; ANUÁRIO DO DISTRITO FEDERAL, 2014). 


\section{Paranoá}

A escola visitada no Paranoá atende o Ensino Fundamental (nos turnos matutino e vespertino) e o Ensino Médio (nos turnos matutino e noturno). Tem uma pequena estrutura física e se localiza próximo à UBS. A Escola oferta atividades extras como oficinas de reforço de português e matemática, oficinas de mosaico, teatro, judô e informática. Os profissionais da saúde atuam com frequência na escola via ações do PSE e são bem participativos nas reuniões com a coordenação central do Programa.

O Paranoá tem uma população urbana estimada em 48.020 habitantes; $47 \%$ na faixa etária de 25 a 59 anos. Crianças na faixa de zero a 14 anos, somam $22 \%$ e idosos representam $12 \%$. Sua principal atividade econômica é o comércio, com lojas de roupas e calçados e bares e restaurantes distribuídos nos três quilômetros da avenida central (ANUÁRIO DO DISTRITO FEDERAL, 2014). Quanto ao nível de escolaridade, a maior proporção de adultos têm o ensino fundamental incompleto; os que possuem nível superior completo representam menos de cinco por cento. O abastecimento de água, energia elétrica, esgotamento sanitário e coleta de lixo estão praticamente universalizados na região (CODEPLAN, 2015).

\section{Itapõ̃}

A escola visitada no Itapoã oferta o ensino fundamental, educação de jovens e adultos, e o ensino médio. Tem uma excelente estrutura física com quadras esportivas e pista de skate dentro da escola. Possui um consultório Itinerante (caminhão baú com consultórios ligados a uma carreta) que faz parte do PSE e visa garantir a saúde bucal de crianças e adolescentes atendidos por dentistas e estudantes de hospitais e universidades federais que, ao dividirem o espaço, também compartilham experiências.

Itapoã é uma região administrativa ainda em consolidação; a ocupação das terras, que antes pertenciam à União, começou em julho de 2001 devido a um aumento populacional na área, com a chegada de famílias oriundas principalmente do Paranoá. Atualmente tem 68.500 habitantes. A totalidade dos domicílios conta com fornecimento de energia elétrica; $99 \%$ são atendidos com iluminação pública; $96 \%$ com o abastecimento de água e $87 \%$ com rede de esgoto (CODEPLAN, 2013).

\section{Sobradinho II}

A escola visitada em Sobradinho II abrange a Educação Infantil e ensino fundamental I e II e tem uma extensa estrutura física. Entre as ações do PSE realizadas 
destacam-se a aplicação de flúor, a realização de exames e atividades de alimentação saudável.

Sobradinho II conta com 100.775 mil habitantes e é formada por assentamentos e diversos condomínios antes pertencentes a Sobradinho. Tem cerca de $80 \%$ dos moradores com renda per capita de até meio salário mínimo e que trabalham com serviços gerais, comércio e construção civil. O abastecimento de água e energia elétrica, atendem quase a totalidade da população mas o esgotamento sanitário abrange apenas um terço dos domicílios (CODEPLAN, 2013).

\section{Plano Piloto}

As escolas visitadas no Plano Piloto são bem diferentes. Uma oferta apenas o ensino fundamental II e tem estrutura física muito pequena; as aulas de Educação Física acontecem em espaço cedido por uma igreja que fica próxima. No entanto desenvolvem diversos projetos e atividades de forma bastante interativa com os alunos tais como o clube do livro e da leitura. Pelo PSE foram desenvolvidas palestras que abordaram temas como: prevenção de acidentes, bullying e perspectivas de trabalho para os escolares. A outra escola atende Educação Infantil, Ensino Fundamental e Educação de Jovens e Adultos na forma de Supletivo. Sua estrutura física é ampla com ginásios de esporte em boas condições, participa de diversas ações e projetos da Secretaria de Educação e demais parceiros.

O Plano Piloto tem uma população estimada em 221.223 habitantes, onde, cerca da metade encontra-se na faixa etária de 25 a 59 anos. Crianças na faixa de 0 a 14 anos somam $12,6 \%$ e idosos representam aproximadamente 25\%. Quanto ao nível de escolaridade, predomina o ensino superior completo alcançando $66,7 \%$ da população. Desses, $18 \%$ possuem cursos de pós-graduação. Não foram encontrados analfabetos morando na região. Quase totalidade dos domicílios conta com o abastecimento de água, energia elétrica e esgoto (CODEPLAN, 2013).

\subsection{PERFIL DOS PARTICIPANTES}

O perfil dos onze professores de Educação Física participantes da pesquisa pode ser visto na Tabela 1. Os relatos das entrevistas indicam que os professores possuem um cotidiano profissional semelhante que se baseia principalmente em ministrar aulas. A maioria dos professores entrevistados ministram aulas teóricas e práticas $(n=7)$, alguns aplicando 
trabalhos e avaliações teóricas $(n=3)$; e que os professores que atuam na Educação Infantil $(n=4)$ ministram aulas exclusivamente práticas.

Tabela 1. Caracterização dos participantes da pesquisa.

\begin{tabular}{lll}
\hline Categoria & Subcategoria & n \\
\hline Gênero & Masculino & 8 \\
& Feminino & 3 \\
Formação & Graduação & \\
em Educação Física & Especialização & 6 \\
& Mestrado & 3 \\
Tipo de ingresso & & 2 \\
na SEE-DF & Concurso & \\
& Contrato temporário & 9 \\
Tempo de atuação & & 2 \\
na SEE-DF & $<2$ anos & 8 \\
& $>5$ anos & 2 \\
\hline
\end{tabular}

Observações das falas e registros no diário de campo sugerem que professores com maior tempo de trabalho na rede de ensino $(n=2)$ apresentaram maior desmotivação em sua narrativa, por outro lado, a maior parte dos professores mais novos tanto em tempo de experiência na rede de ensino quanto na idade cronológica $(n=8)$ apresentou uma postura e um discurso motivado com a profissão durante a entrevista. Não obstante, a maior parte relatou envolvimento apenas com as aulas regulares de sua disciplina. Nenhum professor participava do desenvolvimento das atividades do PSE.

A partir da organização de informações que surgiram nas entrevistas buscamos sistematizar as percepções desses professores sobre três grandes temas: o PSE, a Promoção da Saúde, e a relação desses com as Atividades Físicas ou Práticas Corporais. Esses temas centrais nortearam a criação de categorias e subcategorias, descritas a seguir. 


\subsection{CONHECIMENTOS SOBRE O PSE}

Sobre o PSE conseguimos agrupar informações sobre três categorias: se conhece o programa; que ações do programa eles conhecem; e o que pensam sobre o programa; como vemos no Quadro 8; o número indicado refere-se à quantos sujeitos abordaram o tema na perspectiva daquela subcategoria.

Quadro 8. Percepções de professores de Educação Física sobre o Programa Saúde na Escola.

\begin{tabular}{|c|l|l|c|}
\hline Categoria & Subcategorias & \multicolumn{1}{|c|}{ Temas } & n \\
\hline \multirow{4}{*}{ Conhece } & Como programa & 1 \\
\cline { 3 - 4 } & Como ações (isoladas) & 3 \\
\cline { 3 - 4 } & Não conhece ou só ouviu falar & 7 \\
\cline { 3 - 4 } & \multirow{4}{*}{ Ações } & Avaliação clínica e/ou psicossocial & 1 \\
\cline { 3 - 4 } & & Prevenção & 1 \\
\cline { 3 - 4 } & Práticas Corporais ou Atividades Físicas & 1 \\
\cline { 3 - 4 } & Onformação em saúde & 2 \\
\cline { 3 - 4 } & \multirow{3}{*}{ Opinião } & Favorável & 2 \\
\cline { 3 - 4 } & & Aponta falhas de gestão & 1 \\
\hline
\end{tabular}

Percebemos que na categoria Conhece o PSE, apenas um professor (P1), dentro do universo de onze pesquisados, afirmou conhecer e apresentou em sua narrativa alguns elementos e termos referentes ao Programa como pode ser observado na fala:

P1 - “[...] Então é um programa de promover a saúde na escola que atende todo esse núcleo de abrangência [a escola], ele não visa somente os alunos [...]", e tem também a parte voltada para o profissional de educação, tanto professor quanto servidor". [...] "E ele é desenvolvido com parcerias [...] a parceria junto com outros órgãos do GDF. E nós temos aqui na nossa escola o posto de saúde número 5, se eu não me engano, que é o grande parceiro e traz assim volta e meia algumas ações com esse tema."

Não obstante esse professor não apresentou interesse em participar do programa. Era um professor que estava há mais tempo na Rede de Ensino e que se apresentava desmotivado com a profissão.

Três professores (P2, P4 e P5) demonstram conhecer parcialmente o PSE. Isso significa saber que o programa existe e conhecer algumas ações, mas não apresentam 
conhecimentos específicos sobre o programa como um todo, conforme vemos nas falas a seguir:

P2 - “[...] Não me foi passado nada do programa em si. Eu tive a curiosidade de ler um pouco. De entrar na internet, ver sobre o programa [...]". "É a parte da conscientização, de trabalhar com a criança, principalmente a matéria de educação física, essa preocupação com saúde, tanto dele e da comunidade ".

P4 - "Formalmente, não. Aqui na escola, por exemplo, nunca foi divulgada a questão saúde na escola eu não tenho conhecimento assim, sobre o programa" [...], "mas já vi algumas ações aqui na escola $[\ldots]$ ".

P5 - "[...] Eu conheço a questão da saúde na escola por que eu trabalhei como consultora no MEC. Então lá eu ouvi falar desse programa." [...] "Consiste em fazer atividades, em levar para dentro da escola a questão da saúde".

Os outros sete professores da pesquisa afirmaram não conhecer o PSE, embora três participantes informarem já ter ouvido falar, não tinham nenhuma informação sobre o programa ou como ele funciona. Esses aspectos ficam explícitos nas falas bem diretas e incisivas descritas abaixo:

P3 - "Não. Saúde na escola, não. Acho que não”.

P7 - “[...] Não. O primeiro contato que eu tive foi com você”.

P9 - "Eu já ouvi falar, mas não sei como é que funciona".

Quando fomos identificar a categoria de quais ações conhecem, apenas os quatro professores que conheciam em alguma extensão o programa foram capazes de informar alguma ação, como vemos nas falas abaixo:

P1 - "[...] A maioria das ações foram de informação e de prevenção". [...] "Ah, e teve um projeto de capoeira".

P2 - "Aqui na escola a gente teve alguns encontros [informativos] com o pessoal da regional [da secretaria de educação] que veio aqui fez aquela divulgação da acuidade visual. Distribuíram também uma cartilha do adolescente pra eles acompanharem".

P4 - "Eu já vi aqui na escola, por exemplo, trabalho odontológico, trabalho ligado à psicologia".

P5 - "Consiste em fazer atividades, em levar para dentro da escola a questão da saúde". 
Dado o elevado grau de desconhecimento dos professores, antes de explorar a opinião sobre o PSE, informações gerais sobre o Programa foram fornecidas pela pesquisadora (Apêndice B). Dando seguimento ao diálogo, após o informe, quatro professores expressaram opiniões sobre a ideia geral do PSE:

P1- "É um bom programa né, aqui felizmente a gente conseguiu desenvolver muita coisa boa tá, já tenho notícias que em algumas outras escolas o programa não teve tanta eficácia, mas na nossa escola sempre foi muito bem visto e sempre foi muito bem aceito".

P11- "Eu acho uma proposta excelente até mesmo porque você pode orientar as atividades, e dela os participantes podem usufruir".

P3- "Eu acho que é um projeto que se ele for feito da melhor forma, disciplinado, explicando para os professores e para os alunos a melhor forma de ser feito, acho que é um projeto excelente". [...] "Porque a ideia do projeto é muito boa então se botar certinho, se colocar de uma forma boa $[. .$.$] pode ir para frente."$

P8- "Olha se isso realmente houvesse e fosse planejado por alguém que realmente entende de sala de aula, de movimento, de teoria, era melhor, $[. .$.$] se tivesse prática, se fizesse esse projeto e esse projeto$ fosse apresentado na escola eu acreditaria".

O único professor (P1) que conhece melhor o programa, embora não participe do mesmo, se sente orgulhoso e se inclui no sucesso do programa na escola. Para os demais que não conheciam, acham a ideia boa, mas dois apontam falhas nos aspectos da gestão, organização e comunicação do programa.

É importante destacar que a explanação de um professor entrevistado que informou não conhecer o PSE chamou atenção, pois, na entrada da escola em que ele trabalha há um consultório itinerante (caminhão baú com consultórios ligados a uma carreta) que faz parte do PSE, no qual a logomarca do programa é visível a todos que adentram na escola.

Esta situação sugere que ainda é necessário realizar um amplo processo de sensibilização e incentivo para incluir os professores nas ações do PSE, e que é fundamental fortalecer a participação e o empoderamento desses atores sociais. Não obstante cabe também a reflexão sobre a falta de motivações intrínsecas dos próprios professores para conhecer, entender e participar de maneira colaborativa no programa. $\mathrm{O}$ desconhecimento da relevância social e do enorme potencial transformador de iniciativas de Promoção da Saúde pode ser um dos fatores. Estas considerações são fundamentais para ampliar o debate sobre a importância de solidificar o processo de constituição do PSE na escola. 


\subsection{PERCEPÇÕES SOBRE A PROMOÇÃO DA SAÚDE}

As percepções dos professores sobre o tema da Promoção da Saúde resultou em quatro subcategorias (Quadro 9). Cabe destacar que essas subcategorias foram formadas a partir de diversos momentos nas falas dos participantes sobre o tema e não de respostas específicas a uma questão; cada professor pode apresentar mais de uma percepção sobre o tema.

Quadro 9. Percepções de professores de Educação Física sobre Promoção da Saúde.

\begin{tabular}{|c|l|c|}
\hline \multicolumn{1}{|c|}{ Categoria } & \multicolumn{1}{|c|}{ Subcategorias } & n \\
\hline \multirow{3}{*}{ Promoção da Saúde } & Práticas ou comportamentos saudáveis & 7 \\
\cline { 2 - 3 } & Prevenção de doenças e Ações clínicas & 3 \\
\cline { 2 - 3 } & Formação, Informação e Educação & 4 \\
\cline { 2 - 3 } & Aproximações com a perspectiva ampliada & 3 \\
\hline
\end{tabular}

Vamos nos aprofundar um pouco mais no que cada subcategoria representa no presente estudo. A percepção mais frequente sobre Promoção da Saúde esteve relacionada à Práticas ou comportamentos saudáveis. Nessa perspectiva, as unidades de registro (termos) que apareceram nas falas foram: Praticar ou Fazer atividade física, Acompanhar ou Prescrever exercício físico, Aulas de Educação Física, Medidas de incentivo à saúde, Bons hábitos de vida, Bons hábitos alimentares, Dormir bem, Não usar drogas, Desenvolvimento geral do corpo, Consultar o médico, dentre outros similares. Vejamos o uso termos nos contextos das falas abaixo:

P1 - "Eu fui durante algum tempo né professor do ginásio aqui nas quadras, a própria educação física é um eixo fundamental na Promoção da Saúde dos nossos alunos, assim a gente já tá há mais de vinte anos neste trabalho.” [...] “A prática vai proporcionar saúde né, a informação vai te dar uma blindagem pra que você realmente saiba como buscar a saúde, mas a prática é o ponto culminante".

P4 - "eu já fiz trabalhos também relacionando isso, atividade física voltada para saúde então, foi um projeto do mestrado, da Católica, chamado agendinha. Que trabalhava tanto a parte de alimentação saudável quanto atividade física e durante uma semana era mensurado isso com a criança e a gente continuava esse trabalho e teve algumas turmas que eu consegui fazer isso outras não”. 
P5 - "Eu acho que Promoção da Saúde é pensar é... No corpo, no desenvolvimento como um todo, então ter saúde, praticar atividade física pra ter uma Promoção da Saúde, ter bons hábitos alimentares, consultar o médico constantemente, então eu acho que a Promoção da Saúde começa ai". [...] "Um projeto de extensão enquanto eu era graduanda da UFBA que trabalhava Promoção da Saúde que a gente atendia a comunidade fazia avaliação física e prescrição de exercícios aeróbicos e anaeróbicos".

P7 - Por exemplo, eu trabalho muito com a criação do repertorio motor das crianças, eu acho que Promoção da Saúde entra no repertorio motor, facilitar o conhecimento".

P9 - "Então acredito que essa Promoção da Saúde é melhoria, melhoria da qualidade dos alunos com relação à vivência esportiva, à alimentação" [...] "Participamos da corrida que teve em Brasília do programa medida certa, e da ginastica laboral, então eu tive contato com a Promoção da Saúde".

P10 - “[...] É a pessoa ter bons hábitos alimentares, bons hábitos de qualidade de vida, praticar atividades físicas, praticar esportes. Viver longe das drogas, viver longe da noite, de dormi mal".

P11 - "A questão da atividade física que promove a saúde, o bemestar entendeu, eleva a sua autoestima, não só a questão estética como também, vou citar um exemplo... é combatendo possíveis enfermidades, possíveis doenças, e auxiliando em outras também".

Foram citados como exemplos de Programas de Promoção da Saúde os seguintes: programa de esporte e lazer da cidade; ginástica nas quadras, academia do povo, academia popular, academia da comunidade, academia da saúde; programa medida certa, e de ginastica laboral. O PSE em si não foi citado pelos professores.

Outro entendimento apresentado sobre Promoção da Saúde foi referente à prevenção de doenças e avaliações clínicas. Nessa perspectiva, algumas unidades de registro que apareceram nas falas foram: Evitar doenças, Avaliação física, Acuidade visual, Aplicação de flúor, Nutricionista, Cardiologista, Médico, conforme podemos observar nas falas a seguir:

P2- "Olha a gente teve aqui uma [ação de Promoção da Saúde], essa da acuidade visual, mas, que eu lembre só essa."

P3 - "Promoção da Saúde é mais pelo seguinte, às vezes as pessoas começam a ter certos problemas aí procuram uma atividade física por que tá com esse ou aquele problema ai o médico fala: "você tem que fazer atividade física" aí só faz por causa disso. E tem que ser ao contrário: você fazer atividade física para não sofrer certas coisas lá na frente; e eu acho isso aí excelente". [...] "Agora tem que colocar na 
cabeça de algumas pessoas que a Promoção da Saúde vai depender primeiramente da força de vontade dela, eu vou começar a fazer alguma coisa durante um tempo, regular, disciplinada, para que eu daqui a 5, 10, 15 anos eu esteja melhor do que hoje e não venha sofrer algumas coisas que possam ser ruins para a minha saúde".

P4 - "Acho que promoção de saúde, está muito ligada à medidas que incentivam a saúde, entendeu? É... Acho que... A gente vê projetos muitas vezes isolados, né? De promoção de saúde, então... Alguém que dá atividade física em certo local, né? ... Ou a aplicação do flúor ali... E assim por diante"[...] "Para promover saúde... já levei cardiologista, já levei nutricionista, já trabalhei com parte esportiva, entendeu? E mudando, fazendo avaliação física, conscientizando aquele publico local".

Quando os professores indicam compreender Promoção da Saúde como algo relacionado à Formação, Informação e Educação (em saúde), algumas unidades de registro (termos) que aparecem nas falas foram: formação, informação, orientação, entendimento, conhecimento, conscientização, auxílio, transmitir informações, levar para família, preparar para vida. Vejamos esses termos nos contextos das falas:

P1 - “... é informar, orientar, é praticar, auxiliar, acompanhar, tudo isso é formação".

P5 - "Eu acho que Promoção da Saúde é pensar é... No corpo, no desenvolvimento como um todo, então eu penso que quando a gente trabalha com o aluno ele deve ter também aquela questão do entendimento a gente prepara o aluno pra vida então ele tem que se tornar um jovem sadio, e pra isso ele tem que ter esse conhecimento entendeu, para ele ser um adulto saudável para ele ter bons hábitos alimentares, praticar atividade física, consultar o médico constantemente, então eu acho que a Promoção da Saúde começa ai"

P6 - "É utilizar meios pra informar o aluno sobre saúde. Por exemplo, eu como fiz o curso de enfermagem, eu sei por um lado o que seria a Promoção da Saúde, levando isso para dentro da escola é realmente transmitir as informações importantes para o aluno para que ele adote medidas saudáveis".

P9 - "É melhorar, conscientizar. Então, acredito que é melhorar a saúde tanto dos alunos que são envolvidos na escola como da família porque normalmente a escola traz, passa para o aluno essas medidas e esses programas por que ele tem que levar para fora, levar para casa dele, levar para família".

Cabe destacar que não foram muitos professores e falas que representaram essa percepção formativa ou informativa de Promoção da Saúde. Notamos nesse caso especificamente, que os professores buscam interpretar a Promoção da Saúde relacionando-a 
aos termos promoção e saúde separadamente como, por exemplo, definindo primeiramente a promoção no sentido de proporcionar meios para que se tenha saúde.

Por fim, alguns professores (embora desprovidos de aprofundamento conceitual do termo) foram capazes de apresentar elementos presentes numa perspectiva ampliada sobre Promoção da Saúde ao mencionar os termos (unidades de registro): contexto, bem estar, aspectos simples e complexos relativos à saúde, trabalho em grupo, interação, cooperação, tratamento com o outro, amizade, segurança, autoconfiança, autoestima, ideias saudáveis, relacionamentos saudáveis, além da cultura corporal. Vejamos os termos aplicados no contexto das falas:

P1 - "[Promoção da Saúde], ela está em todo um contexto, então tudo que é relativo à saúde, seja da forma mais simples ou da forma mais complexa é promoção de saúde".

P2 - "Eu acho que é todo trabalho feito com as crianças, em grupo e principalmente na minha matéria educação física onde trabalho além da cultura corporal. De todos os movimentos, trabalho também a questão do grupo, da interação deles, da cooperação. Isso é muito importante, muitos alunos tímidos tem toda essa coisa de não fazer amizade e... Na educação física eles, conseguem trabalhar melhor isso ai".

P8 - "A saúde não é só o exercício físico, é o tratamento com o outro, é o respeito que você tem com o outro, é a segurança [autoconfiança] que você promove então você tem que buscar vários elementos para falar de saúde né, até de ideias, você tem que ter ideias saudáveis, relacionamentos saudáveis, é muito complicado não é fácil".

\subsection{PERCEPÇÕES SOBRE AS PRÁTICAS CORPORAIS E ATIVIDADES FÍSICAS E SUA RELAÇÃO COM A PROMOÇÃO DA SAÚDE}

No que diz respeito aos fenômenos das Práticas Corporais ou Atividades Físicas com a Promoção da Saúde, três professores direcionaram suas percepções à esfera individual, comportamental, na perspectiva preventiva, onde o sujeito é culpabilizado por suas ações (Quadro 10). Os demais professores não abordaram sobre o assunto de forma especifica e/ou não foi perguntado. 
Quadro 10. Percepções de professores de Educação Física sobre o tema Práticas corporais e Atividades Físicas e sua relação com a Promoção da Saúde.

\begin{tabular}{|c|l|c|}
\hline Categoria & \multicolumn{1}{|c|}{ Subcategorias } & n \\
\hline Relação das Práticas & Informação (perspectiva prescritiva) & 1 \\
\cline { 2 - 3 } $\begin{array}{c}\text { corporais, Atividades Físicas } \\
\text { e Promoção da Saúde. }\end{array}$ & $\begin{array}{l}\text { Práticas e hábitos individuais (perspectiva da } \\
\text { culpabilização) }\end{array}$ & 2 \\
\hline
\end{tabular}

As falas abaixo representam as percepções vigentes:

P1 - "Uma coisa está diretamente ligada à outra não tem como desassociar". Não adianta você só ter a informação e não ter a prática".

P3 - "Agora tem que colocar na cabeça de algumas pessoas que a Promoção da Saúde vai depender primeiramente da força de vontade dela, eu vou começar a fazer alguma coisa durante um tempo, regular, disciplinada, para que eu daqui a 5,10,15 anos eu esteja melhor do que hoje e não venha sofrer algumas coisas que possam ser ruins para a minha saúde".

P10 - “[...] É fundamental porque na Promoção da Saúde a gente precisa se alimentar bem, praticar atividade física, não pode ter uma vida sedentária, ter bons hábitos, eu acho que já é inerente do caso da educação física abordar essa área da saúde [...]”. 


\section{DISCUSSÃO}

\section{A valorização teórica e a inexistência das Práticas e Atividades Corporais no PSE-DF}

As práticas corporais e atividades físicas são apontadas como ações prioritárias na PNPS (MALTA et al., 2014) onde são consideradas importantes ferramentas para fortalecer o cuidado individual e coletivo na atenção básica e em todas as esferas do SUS, a partir da articulação entre diferentes áreas técnicas, programas e políticas numa abordagem da Promoção da Saúde (BRASIL, 2006; SÁ et al., 2016).

O desenvolvimento de Escolas Promotoras de Saúde também é uma possibilidade concreta ao se levar em conta a realidade da implantação dos Parâmetros Curriculares Nacionais no Brasil, onde a disciplina de Educação Física aparece com seu potencial inclusivo, agregador, social, de superação e com a inserção da saúde como tema transversal (BRASIL, 1998).

A implantação e a expansão do PSE em todo território nacional fortalece a Promoção da Saúde no contexto escolar por meio da ampliação de possibilidades para a construção de melhores condições de vida (BRASIL, 2007a). Ao considerarmos os contextos social e econômico desfavoráveis nos quais algumas escolas visitadas se encontram (em regiões periféricas marcadas por violência, baixos níveis educacionais, escassez de emprego e saneamento básico precário) ampliamos a relevância de que a Promoção da Saúde seja efetivada de forma sustentável pelo PSE (FERREIRA et al., 2014).

Mais uma vez as práticas corporais e atividades físicas são consideradas um relevante eixo de ação para o fortalecimento da saúde e do ambiente escolar saudável (HARADA et al. 2003), principalmente se utilizadas como um recurso interdisciplinar e intersetorial que favoreça para que os indivíduos e as coletividades tenham controle de suas vidas e de sua saúde (ROCHA; MARCELO; PEREIRA, 2001). As práticas corporais têm um papel importante no desenvolvimento humano, sobretudo de crianças e adolescentes em localidades com altos índices de vulnerabilidade social (BRASIL, 2007a). São ações que, quando planejadas e implementadas de forma participativa, podem contribuir na promoção da cultura de paz, da ética, da cidadania, da participação e da qualidade de vida (BAGRICHEVSKY, 2007).

Apesar da importância das Práticas Corporais e Atividades Físicas para o desenvolvimento e melhoria da qualidade de vida de crianças e adolescentes esse eixo ainda é reconhecido nas normativas do PSE como ação optativa para realização. 
Não obstante as associações das práticas corporais com a Promoção da Saúde no contexto escolar, identificamos a inexistência de práticas e atividades desse eixo de ação desenvolvidas num contexto regular a partir do PSE no DF. Além da ausência das ações nas escolas que aderiram ao PSE, houve ainda um grande desconhecimento sobre o programa e uma falta de envolvimento com o desenvolvimento dessas ações por parte dos professores de Educação Física nas escolas visitadas.

Por deter um conhecimento científico e metodológico do tema, o professor de Educação Física deveria ser uma liderança no processo de organização e desenvolvimento dessas práticas e atividades corporais promotoras da saúde (BETTI; ZULIANI, 2002). Por sua característica prática e participativa, as aulas de Educação física poderiam direcionar os processos educativos para além da transmissão de conhecimentos e atitudes lineares e prescritivas em saúde. Poderiam focar na identificação e no enfrentamento das dificuldades, no fortalecimento da identidade, na incorporação de soluções criativas e saberes saudáveis (MORETTI et al., 2009), tendo como objetivo final reduzir as iniquidades e estimular o empoderamento dos indivíduos e grupos para atuar sobre sua saúde (BUSS; CARVALHO, 2009). As práticas corporais se constituem como uma excelente estratégia no processo de transformação e melhora das condições de vida da comunidade escolar (CARVALHO, 2012b).

Os professores das escolas visitadas não conheciam e não se envolviam com o PSE, seja porque não foram convidados a participar; ou não se interessaram em participar; e/ou porque os docentes consideram que as ações do PSE não são tarefas deles e sim, somente dos profissionais da saúde (SANTOS; SANTOS; GOMES, 2015). Sabe-se que o contexto escolar ainda apresenta dificuldades de uma gestão inovadora, integrada e participativa, inclusive para o desenvolvimento de seu Projeto Político Pedagógico, dificultando o reconhecimento do papel ativo e fundamental dos professores, alunos e comunidade nos processos de construção da realidade (OLIVEIRA; MARTINS; BRACHT, 2015).

Reconhecemos também que os documentos normativos do PSE apresentam algumas inconsistências conceituais sobre promoção da saúde e prevenção de doenças (TUSSET, 2012) e não abordam de maneira explícita os saberes pedagógicos da Educação Física, embora destaquem alguns temas que lembram seus elementos conceituais e de prática tais como: prática corporal, atividade física; estilo de vida ativo; qualidade de vida; entre outros. No entanto, falta reconhecer o papel central da Educação Física enquanto componente 
curricular do programa, com grande potencial para colaborar de forma multi ou interdisciplinar para a Promoção da Saúde (SANTOS; MEZZAROBA, 2013).

Mesmo sem abordar como deve ser a relação do professor de Educação Física da escola com as ações do Programa, é de suma importância que os atores-chave (incluindo os professores de Educação Física) se vinculem aos processos de planejamento e desenvolvimento das atividades, tendo em vista a adesão e o comprometimento prévio da escola com o PSE (BRASIL, 2011). Quando não acontece o debate sobre o programa e a apropriação do mesmo pelos agentes escolares, o PSE se torna mais um programa impelido verticalmente para dentro da escola, impactando de forma desfavorável sua implantação (OLIVEIRA; MARTINS; BRACHT, 2015).

Vejamos a seguir aspectos mais específicos sobre as percepções dos professores de Educação Física a respeito desses três grandes temas: o PSE, a Promoção da Saúde, e as práticas corporais ou atividades físicas no contexto do PSE no DF.

\section{O desconhecimento e a não participação dos professores de Educação Física no PSE-DF}

O planejamento das ações do PSE deve ser inserido no Projeto Político Pedagógico da escola considerando-se a diversidade sociocultural das diferentes regiões do país e a autonomia dos educadores e de suas equipes pedagógicas (BRASIL, 2007a). Apesar das indicações nas normativas do PSE elencarem o planejamento e a execução das ações do programa de forma integrada com o Projeto Político Pedagógico e, consequentemente, com a efetiva participação dos professores, foi possível identificar que essa recomendação não é uma realidade no cotidiano das escolas nas quais estes profissionais atuam.

$\mathrm{Na}$ presente pesquisa, a maioria dos professores de Educação Física entrevistados sequer conheciam o PSE ou não apresentam conhecimentos mínimos sobre o programa. Apenas um professor apresentou em sua narrativa alguns termos próximos aos abordados nas normativas do PSE como parceria (intersetorialidade) e comunidade escolar, e foi capaz de descrever algumas ações pontuais realizadas na escola na qual atua. Contudo, o desconhecimento sobre o programa não é uma realidade apenas dos profissionais da educação. Resultados de uma pesquisa semelhante ao presente estudo também identificaram um expressivo desconhecimento do PSE por parte dos profissionais que atuavam na Unidade Básica de Saúde (JACÓE et al., 2014).

Embora as falas relacionadas ao desconhecimento sobre o PSE critiquem aspectos da gestão do programa, e estas possivelmente estejam ocorrendo, um caso específico chamou a 
nossa atenção para outra perspectiva complementar: um professor entrevistado informou não conhecer o PSE mesmo existindo na entrada da escola um caminhão com uma enorme logomarca do programa onde funciona um consultório odontológico. Nota-se, nesse caso específico uma distração ou total falta de interesse por parte do professor em se informar (e se envolver) com as atividades da escola na qual atua. É possível que essa seja uma das consequências quando a implantação do PSE ocorre como mais um programa compelido para dentro da escola (OLIVEIRA; MARTINS; BRACHT, 2015); o que parece ser um problema recorrente no PSE (JACOÉ et al., 2014).

O envolvimento dos profissionais e das instituições por meio de um empenho conjunto é fundamental para que a promoção da saúde seja implementada e a qualidade e a melhoria das ações em saúde sejam alcançadas. Conforme apontam as diretrizes do PSE, a participação de representantes das secretarias da Saúde e Educação, do corpo docente, do corpo discente e da comunidade local deveria ser equânime em todas as etapas do processo (BRASIL, 2011). Só assim o PSE poderia se constituir como uma ferramenta que favoreça o vínculo e a troca de experiências e conhecimentos entre todos os atores envolvidos, profissionais da saúde e educação, público escolar e a comunidade como um todo (GODOI; POL; MATIA, 2012).

Observamos assim que, apesar de existirem políticas públicas que preconizam a ação conjunta de diferentes atores e setores, há um certo distanciamento entre os documentos oficialmente instituídos e as práticas incorporadas pelos profissionais, sendo necessário desenvolver uma cultura local participativa e intersetorial entre gestores e profissionais (PENSO et al., 2013). No caso do PSE parece que os atores escolares em geral esperam que as iniciativas para a concretização das ações do programa partam do setor saúde (LEITE et al., 2015).

Por sua vez, essa expectativa pode estar relacionada ao reconhecimento da centralização e do protagonismo do setor saúde em ações como: o financiamento; o processo de adesão; e a coordenação da comissão intersetorial do PSE (FERREIRA et al., 2012). Muitas vezes chegam equipes de diferentes áreas nas escolas propondo uma avalanche de projetos e ações isoladas, desarticuladas, superpostas e descontínuas, quando não com diretrizes e intencionalidades díspares (ROCHA; MARCELO; PEREIRA, 2002; MAGALHÃES, 2015). Se a participação dos setores não é equânime no processo de planejamento, implantação e manutenção de programas e ações de saúde no ambiente escolar 
não há uma real intersetorialidade, sendo esse um desafio premente do PSE (FERREIRA et al., 2012; GOMES, 2012).

A falta de articulação, o desconhecimento e o pequeno envolvimento de atores e setores centrais ao programa são fatores de insucesso no decurso de implementação do PSE. Esses resultados podem advir de falhas de gestão e de certo comodismo aliados a uma compreensão limitada dos projetos propostos (LEITE et al., 2015). Num círculo vicioso, esses processos fragilizam a participação e o desenvolvimento das ações, dificultam o atingimento dos objetivos propostos e aumentam o descrédito dos profissionais e da população nos programas institucionais (OLIVEIRA; MARTINS; BRACHT, 2015).

Não se trata de responsabilizar o gestor ou o professor de forma individual, pois reconhecemos os determinantes políticos, econômicos, culturais e ambientais nos processos de elaboração de políticas públicas e programas de saúde e de educação do Brasil, que em geral adotam a perspectiva top-down, significando uma abordagem verticalizada que compele os programas a partir do nível da gestão (JACÓE et al., 2014). Mas é necessário refletir como os processos de participação e cooperação entre os atores e os setores da educação e da saúde podem ser ampliados no PSE. No caso do presente estudo destacamos a seguir dois aspectos relativos ao professor de Educação Física que acreditamos afetar seu envolvimento com o Programa: uma postura desmotivada com a profissão e o desconhecimento sobre os referenciais teóricos do PSE e da promoção da saúde.

\section{Postura dos professores de Educação Física em relação ao PSE-DF}

Ao observar as motivações e disposições dos professores em relação às suas práticas no cotidiano escolar podemos constatar que alguns destes profissionais, embora jovens e recém contratados para atuar nas escolas, sentem-se desmotivados no exercício de suas atividades e decepcionados com o descaso e o abandono da educação de um modo geral. Resultado semelhante foi evidenciado no estudo de Porath et al. (2011) o qual identificou dois sentimentos presentes na trajetória profissional dos professores de Educação Física: o desinvestimento amargo pautado pelo descaso governamental e o desinvestimento sereno retratado pelo período de afastamento da docência, o qual os docentes podem investir em seus projetos pessoais.

Embora esse não seja um foco do presente estudo, a literatura aponta que o trabalho docente na área da Educação Física pode ser caracterizado por sentimentos negativos que comprometem a qualidade do trabalho. Vivências subjetivas de desgaste físico e emocional 
acumuladas no trabalho traduzem-se, com o passar do tempo, em sentimentos depressivos e em fadiga crônica, compondo um estado anímico denominado Síndrome do Esgotamento Profissional (SANTINI; NETO, 2005).

A desmotivação dos professores em geral contribui e é um reflexo da situação do sistema educacional do País, em especial as escolas públicas, muitas vezes caracterizadas por sua estrutura precária em localidades de alta vulnerabilidade (pobreza, violência, preconceito, pouca infraestrutura urbana, dentre outros). O pequeno envolvimento dos pais de alunos e da comunidade e a desvalorização do professor acentuam esse processo, desestimulando inclusive a formação continuada desses profissionais (ASSIS, et al., 2013). No presente estudo, menos da metade dos professores de Educação Física deu seguimento à sua formação após a graduação.

No entanto, é importante destacar que quando as ferramentas e possibilidades de melhorias dessas condições se apresentam (como por exemplo, a adesão da escola ao PSE), é necessário o esforço conjunto da comunidade escolar para que todos os atores assumam uma postura participativa que considere as dimensões e as possibilidades de melhoria da qualidade de vida nos processos de planejamento e concretização das atividades propostas na escola (GOMES, 2012). Sendo a Educação Física uma profissão da grande área da saúde, mas também uma licenciatura, estando intimamente relacionada ao processo de educação, consideramos relevante que seus professores se envolvam de forma efetiva, adotem papeis de liderança nesses processos e contribuam na formação integral de crianças e jovens para a apropriação crítica da cultura corporal de movimento (BRASIL, 2001; BETTI; ZULIANI, 2002).

No caso especifico do PSE, se as decisões e o processo de planejamento e implantação das ações não são realizados de forma conjunta e democrática, há possibilidades de insucessos no andamento do Programa (FERREIRA et al., 2012). Para reverter essa situação, o professor deve assumir seu papel central no envolvimento com a realidade social e com o processo de desenvolvimento e aprendizado dos alunos e alunas no ato de educar, uma prática pedagógica com importante função de comunicação e informação (ONOFRE, 2000). Nesse sentido, as concepções e os modo de trabalho de cada profissional são fatores que podem facilitar ou dificultar o andamento de projetos e iniciativas de melhoria do ensino (BOLZAN; MILLANI, 2011). 


\section{O desconhecimento dos professores de Educação Física sobre os referenciais teóricos do PSE e de Promoção da Saúde}

O desconhecimento dos entrevistados sobre os referenciais teóricos do programa é explícito. Mesmo após uma breve explanação sobre os propósitos e princípios do PSE, apenas quatro professores tiveram interesse em manifestar uma opinião sobre o programa, sendo que desses, dois adotaram uma postura crítica e descrente de que o PSE pudesse atingir os objetivos propostos.

De forma contraditória, um estudo desenvolvido com representação de um município de cada região do país (Norte, Nordeste, Centro-Oeste, Sudeste e Sul), indicou que a maioria dos profissionais da saúde e da educação entrevistados perceberam o PSE como um programa que promove a cidadania e a garantia de direitos humanos nos territórios de atuação (FERREIRA et al., 2014). Talvez a diferença na perspectiva se justifique devido ao enfoque territorial amplo (nacional) que a pesquisa atingiu ou ao perfil diferenciado dos entrevistados (gestores locais).

Ao analisarmos as percepções dos professores de Educação Física sobre Promoção da Saúde notamos que a tendência prevalente foi de interpretá-la no âmbito das práticas e/ou comportamentos tidos como "saudáveis", da prevenção de doenças e de ações clínicas. Concepções que se aproximam de um olhar ampliado foram incipientes entre esses professores. Diversos outros estudos apontam que essas limitações conceituais são prevalentes entre os profissionais da área da saúde e da educação (NEVES, 2006; RONZANI; COSENZA, 2006; ARAUJO, 2011).

A Promoção da Saúde e a intersetorialidade são ferramentas de transformação das condições de vida e de saúde de sujeitos e coletividades respaldas por uma visão integrada dos complexos problemas sociais da atualidade e através de múltiplas estratégias que envolvem atores, instituições, saberes, práticas, englobando assim todos os componentes ligados à saúde: social, econômico, político, biológico, cultural, étnico-racial e espiritual (CARAVALHO, 2012b).

Percebemos que o entendimento e reconhecimento do que significado da Promoção da Saúde em uma perspectiva ampliada destaca-se como primeiro obstáculo para diminuir as dificuldades para realizar tais ações na escola (TEIXEIRA, 2006). Tais aspectos relacionados às bases conceituais da formação em Educação Física também condicionam a pouca participação (ou em alguns casos nenhuma) dos profissionais desta área em ações norteadas pela perspectiva ampliada da Promoção da Saúde. 
Não obstante, diversos outros estudos confirmam a predominância das ações clinicas e preventivas no PSE (ALBUQUERQUE; MENEZES, 2010; ASSIS; PIMENTA; SCHALL, 2013; PRADO; LIMA, 2013; TEIXEIRA et al., 2014; OLIVEIRA; MARTINS; BRACHT, 2015); o que nos leva novamente à reflexão sobre os processos cíclicos que ocorrem entre a concepção e a ação em Promoção da Saúde (SÍCOLI; NASCIMENTO, 2003).

Embora considerados complementares nas práticas relacionadas aos processos de saúde e doença, é importante reconhecer as diferenças teóricas presentes nos enfoques de prevenção de agravos e de promoção da saúde (TEIXEIRA, 2006). Cada um dos termos mantém especificidades conceituais ligadas à visões de mundo e à projetos de sociedade diferentes e conflitantes que se expressam nas formas de conceber e organizar os discursos e as práticas relativas aos seus saberes e conhecimentos (MOROSINI, 2009).

A promoção da saúde se caracteriza pela busca da conservação ou expansão da vitalidade humana, vista como totalidade irredutível, decorrente de atividades e hábitos cotidianos afetados por fatores estruturais das sociedades em que vivemos (LUZ, 2007). Já a prevenção de agravos em geral se dirige à transformação de fatores de risco comportamentais na perspectiva individual (BUSS, 2000).

Talvez o maior desafio no desenvolvimento do PSE esteja relacionado ao processo de transformação das experiências classicamente cognitivas e curativas pela possibilidade de desenvolvimento humano integral que permita interferir, de diversas formas, em aspectos até então desconhecidos pelos educandos, ampliando sua participação na construção de uma vida melhor (BRASIL, 2009). O entendimento e aproximação com o enfoque ampliado de Promoção da Saúde pode contribuir com formas inovadoras de atuar no processo saúdedoença no interior da sociedade e o desenvolvimento de ações transformadoras no modelo tradicional de ensino, favorecendo os processos de articulação e participação (ROCHA; MARCELO; PEREIRA, 2002; FIGUEIREDO; RODRIGUES-NETO; LEITE, 2009).

Essa perspectiva definitivamente não é a dos professores de Educação Física entrevistados. Quando alguns deles citaram as ações percebidas como sendo do PSE houve destaque para atividades de informação e conscientização bem como de avaliações clínicas e de prevenção de doenças e agravos. E quando indagados sobre as relações existentes entre as práticas corporais e atividades físicas com a Promoção da Saúde as respostas foram centradas na perspectiva individual de comportamentos e hábitos saudáveis que podem prevenir doenças. 


\section{As relações das Práticas corporais e atividades físicas com a Promoção da Saúde}

Apenas três professores do presente estudo apontam de forma explícita relações existentes entre as práticas corporais e atividades físicas com a Promoção da Saúde. No entanto, essas percepções relacionais não resultaram na participação dos professores no desenvolvimento das ações do PSE e estiveram marcadas por visões restritas de Promoção da Saúde.

O estudo de Oliveira, Martins e Bracht (2015) - que buscou compreender as relações da Educação Física com o PSE a partir da visão de professores de Educação Física de uma escola pública de Vitória, Espírito Santo - apresentou que, de seis entrevistados, apenas uma professora destacou que não cabem ações colonizadoras (o protagonismo do setor saúde) sobre o tema da saúde na escola, mas sim diálogos e aproximações que visem a Promoção da Saúde de acordo com as reais necessidades que emergem em cada contexto educacional.

As relações apontadas pelos professores de Educação Física participantes da pesquisa estiveram centradas na perspectiva de que o individuo é culpabilizado por não adotar as atitudes saudáveis prescritas pelos profissionais. Outro estudo com professores de Educação Física da rede municipal de Fortaleza, Ceará também identificou hegemonia da relação causal entre atividade física e promoção da saúde no discurso, embora apenas uma minoria tenha apresentado alguma referencia ao tema numa perspectiva de Saúde Coletiva, que vai além da responsabilidade individual em realizar a prática prescrita (FERREIRA; OLIVEIRA; SAMPAIO, 2013).

Outra publicação também apresentou a coexistência de três correntes teóricas para a abordagem de saúde na educação física escolar brasileira: a aptidão física relacionada à saúde; a atividade física e saúde com foco nos conhecimentos da epidemiologia (diagnósticos populacionais ou com o foco em intervenções); e a abordagem crítica. Contudo, na visão dos autores, tais concepções compreendem a Promoção da Saúde com superficialidade teórica, isolada em ações voltadas ao aumento das práticas de atividades físicas e de forma estritamente comportamentais, refletindo um distanciamento do ideário moderno de Promoção da Saúde (KNUTH; LOCH, 2014).

Um estudo recente que buscou compreender as concepções de Promoção da Saúde entre estudantes do curso de Bacharelado Interdisciplinar em Saúde da Universidade Federal da Bahia identificou quatro diferentes concepções de Promoção de Saúde, com suas respectivas prevalências: i) 45,2\% associam com Bem-estar/Qualidade de Vida; ii) 27,4\% 
com políticas ou ações sociais em saúde; iii) 22,6\% com estilo de vida saudável; e iv) 4,8\% com ausência de doenças (CARDOSO, 2015).

Uma revisão bibliográfica sobre saúde na escola na América Latina aponta que são constantes no contexto escolar iniciativas centradas na doença e em suas formas de transmissão; ações de triagens e de construção de perfis epidemiológicos; e estratégias educativas relacionadas à transmissão de conhecimentos sobre prevenção, higiene e primeiros socorros (CASEMIRO; FONSECA; SECCO, 2014).

Na maioria das situações, a escola tem sido um lugar para o controle e a prevenção de doenças porque o setor saúde costuma ver o ambiente escolar como espaço no qual os alunos são um grupo passivo para a realização de ações clínicas em saúde (CERQUEIRA, 2007). Uma realidade que se consolidado em consonância com os fenômenos emergentes das transições nutricional e demográfica e com o crescente destaque dado à atividade física na prevenção das doenças crônicas (BRASIL, 2006; 2007; 2011).

Cuidados clínicos e individuais na escola resultam de uma determinada demanda específica, mas é relevante coordenar ações no domínio dos determinantes sociais em saúde, dado o contexto de vulnerabilidade social no qual o público das escolas públicas e do PSE está inserido (GOMES; HORTA, 2010). Quando pensado em uma concepção biomédica e preventivista, a promoção e a educação em saúde têm sido pouco efetivas para provocar mudanças e melhorias de vida dos escolares (FIGUEIREDO; MACHADO; ABREU, 2010).

Assim, podemos perceber que o vínculo entre Saúde e Educação nem sempre tem sido conciliador; frequentemente os professores se queixam de que o setor saúde usa a escola e abusa do tempo disponível com ações isoladas que poderiam ser mais proveitosas, com programas mais participativos e protagonista de atenção à saúde (CERQUEIRA, 2007).

No caso das práticas corporais e atividades físicas, observamos que esta se aproxima fortemente da saúde através do movimento da AFRS que surge na década de 1980 e se fortalece a partir da ampliação dos estudos científicos de base epidemiológica e benefícios fisiológicos (FERREIRA, 2001). Nessa perspectiva, a atividade física vem sendo entendida como uma fórmula prescritivo-normativa 'receitada' aos sujeitos, pautada na crença 'ingênua' de que é uma ação redentora de todos os possíveis males do sedentarismo (CARVALHO, 2008).

Contrapondo-se a estas ideias, o autor defende que o fomento da prática regular de atividade física seja analisado diante do contexto de vida dos sujeitos e de forma subsequente o enfrentamento dos determinantes da sua saúde (CARVALHO, 2008). Não se trata de 
desconsiderar os benefícios da atividade física à aptidão física e à prevenção e controle de doenças, mas de reconhecer que pouca atenção tem sido dada aos fatores sociais mais amplos que determinam os hábitos e comportamentos como, por exemplo: a educação, a renda, o ambiente, o trabalho, a habitação, o transporte, o lazer e a liberdade (FERREIRA, 2001).

Ao abordar o tema da saúde no contexto escolar a Educação Física deve levar em consideração o caráter multifatorial da saúde, incorporando os determinantes sociais, econômicos, políticos, culturais e ambientais do exercício, da aptidão física e do desporto. A compreensão da influência (e a modificação) desses fatores na adesão ao exercício físico por parte dos alunos é uma grande contribuição da educação física escolar (FERREIRA, 2001). Nessa perspectiva mais promotora de saúde, é necessário considerar a aproximação dos saberes entre os campos da Saúde Coletiva e da Educação Física (CARVALHO, 2008; NOGUEIRA; BOSI, 2016)

Não obstante, nos deparamos com uma percepção, uma contextualização e uma realidade do PSE centradas em abordagens limitadas e ultrapassadas de Promoção da Saúde; reflexo dos modelos de produção de saberes e práticas dos campos científicos da Saúde, Educação Física incluída, ainda centrados nos modelos biomédicos, preventivistas, prescritivos e individualistas (LOCK, 2011; NOGUEIRA, 2014). Professores de Educação Física jovens e recém ingressos no mercado de trabalho da educação formal apresentaram concepções ultrapassadas que deveriam ter norteado a formação profissional no século passado.

\section{Diferenças entre Promoção da Saúde, Educação em Saúde e Prevenção de Doenças}

As diferentes percepções sobre Promoção da Saúde são reflexos de contextos históricos e embates teóricos recorrentes desde as décadas de 1970 (BUSS; PELLEGRINI FILHO, 2007). A polissemia do conceito da Promoção da Saúde ainda é uma realidade tanto no contexto teórico quanto em suas ações e práticas (SÍCOLI; NASCIMENTO, 2003; TEIXEIRA, 2006; CZERESNIA, 2009). Embora avanços mais sistemáticos estejam sendo alcançados em termos conceituais, há maiores dificuldades de colocar em prática a dimensão metodológica ampliada nas ações práticas de Promoção da Saúde no cotidiano dos profissionais envolvidos com esse campo. A complexidade que envolve a Promoção da Saúde se mantém um desafio constante no cotidiano dos profissionais, sejam eles da saúde ou educação (MORETTI et al., 2009). 
As concepções vigentes no presente estudo apontam para confusões conceituais entre Promoção e Prevenção, já abordados na parte introdutória do trabalho, mas também entre Promoção e Educação em Saúde. Percebemos nas narrativas dos professores entrevistados as relações entre Promoção da Saúde e Educação em Saúde a partir do uso de termos como: ações educativas, informação, orientação, auxílio, formação, entendimento, conhecimento, conscientização, preparar para vida, transmitir informações, levar para família, foram utilizadas para definir Promoção da Saúde.

Estabelecer essa diferenciação epistemológica em Promoção da Saúde é fundamental pois, segundo Breilh (1997), "uma distorção mil vezes repetida acaba convertendo-se em ingrediente de uma interpretação da realidade", resultando na manutenção das relações sociais e da própria saúde (MOROSINI; FONSECA; PEREIRA, 2009).

Apesar de haver diferenças entre os seus significados, a estreita relação existente entre a Promoção da Saúde e a Educação em Saúde está implícita na própria definição apresentada na Carta de Ottawa (OPAS, 1986). Considerada um componente e uma ferramenta central da Promoção da Saúde a Educação em Saúde pode ser definida como o somatório de todas as influências que coletivamente determinam conhecimentos, crenças e comportamentos relacionados com a saúde nos indivíduos e comunidades (BRITO, 2014). A Educação em Saúde não se restringe ao repasse de conhecimentos, mas busca embasar a construção de conhecimento aliado à conquista da autonomia e a melhores condições de vida para os sujeitos e comunidades (SILVA-ARIOLI et al., 2013).

Essa perspectiva pressupõe que todos os indivíduos recebem Educação em Saúde de várias formas ao longo da vida, seja na educação formal ou informal como, por exemplo, na família, na escola e na sociedade (BRITO, 2014); e que a prática educativa está inserida em um contexto pedagógico transformador, construída e pautada no diálogo, no exercício da consciência crítica reflexiva, e que prioriza a transformação da realidade e das pessoas envolvidas por meio da ampliação da capacidade de entender a complexidade dos determinantes do ser saudável (BUSS, 2009).

Ao buscar compreender a percepção de professores das escolas públicas da cidade de São Paulo sobre cidadania, Bydlowski, Lefèvre e Pereira (2011), identificaram que todos os professores entrevistados referem-se à escola como um espaço onde a cidadania deve ser ensinada como tema transversal, seguindo a orientação dos Parâmetros Curriculares Nacionais. Entre as diversas propostas de ação feitas pelos os professores destacam-se: abordar o tema por meio de projetos, revistas, jornais e elaboração de textos; e buscar a 
sensibilização e a participação dos alunos através do diálogo, de questionamentos e de comentários no decorrer das aulas.

Outro estudo que também abordou o tema da Educação em Saúde apresentou duas diferentes abordagens voltadas para o planejamento de atividades de Educação em Saúde apontando que mudanças individuais e organizacionais devem ser realizadas para que os atores envolvidos sejam capazes de compreender suas funções e seus papéis na prática e de conduzir as ações e intervenções de forma viável (CANDEIAS, 1997).

No contexto das aulas de Educação Física escolar a educação em saúde precisa abordar outros aspectos com a mesma ênfase dada aos impactos na saúde física. Temas como a violência, o bullying, a pobreza, a infraestrutura precária, a falta de participação dos pais na vida escolar dos filhos, a desmotivação de professores, e o papel que os adolescentes desempenham na família, no bairro, e em sua escola são alguns exemplos (CARVALHO, 2012b). Discutir esses temas e realizar dinâmicas participativas pode ser o primeiro passo para promover formas de superar essas vulnerabilidades sociais. A aproximação com os referenciais modernos da Promoção da Saúde pode representar uma saída pra discutir a promoção de uma vida saudável nesse contexto.

\section{As produções científicas sobre o PSE}

O panorama de confusões conceituais e desconhecimento sobre o PSE nos faz considerar relevante refletir sobre a atual produção de conhecimentos a partir do meio acadêmico-cientifico. Ao realizar a revisão da literatura das publicações científicas (artigos, dissertações e teses) sobre o PSE, encontramos uma quantidade razoável de estudos mas, devido à amplitude e abrangência do programa, a diversidade de temas, de delimitações e de abordagens nos estudos dificulta que cheguemos à conclusões.

Não obstante, é possível identificar algumas características gerais na análise conjunta dos estudos que nos permite perceber semelhanças com o panorama apresentado no presente estudo; são elas: i) a despeito de os autores em geral reconheceram a relevância teórica do PSE como uma estratégia intersetorial de cuidado integral aos escolares que estimula e mobiliza a articulação entre os setores da saúde e da educação, sua implementação não ocorre de forma homogênea e há limitações tanto no desenvolvimento quanto na avaliação das ações desenvolvidas; ii) a Promoção da Saúde foi abordada nos estudos com superficialidade teórica e, em geral identificada de forma isolada em ações comportamentais e individuais ou seja, há pouca familiaridade dos autores com o conceito ampliado de Promoção de Saúde; iii) o 
modelo preventivista, focado na ausência de doenças foi hegemônico nos estudos pesquisados.

Embora houvessem diversos estudos qualitativos sobre o tema - através de técnicas de entrevistas, análise de documentos, relatos de experiências e/ou revisão de literatura foram poucos artigos que se destacaram por realizar pesquisas qualitativas seguindo os critérios metodológicos de qualidade (HORSBURGH, 2003).

Dentre os estudos quantitativos, a ênfase esteve nos fatores ou comportamentos de risco individual, com a realização de testes físicos e questionários com intuito avaliar a saúde de escolares na perspectiva clínica, psicossocial ou física, centrado na descrição de prevalências. Essas características descritivas não contribuem com as discussões sobre os motivos que levam à atual situação de sedentarismo e adoecimento em escolares.

A ênfase dada aos estudos epidemiológicos, pautados na lógica hegemônica biomédica, bem como as ações realizadas para reduzir os fatores comportamentais de risco não pode ficar restrita à esfera do indivíduo uma vez que mantém relação com o sistema político, econômico e cultural em que estão inseridos (GIACOMOZZI, 2012). É importante reconhecer possibilidades ampliadas de estudos e que abordem temáticas que possam contribuir de forma efetiva no cotidiano dos escolares como, por exemplo, a redução do uso de drogas, da violência, e a melhoria do estado de saúde dos escolares com pauta nos Determinantes Sociais da Saúde.

Identificamos carência de estudos científicos sobre a efetividade das intervenções em Promoção da Saúde que apresentem abordagens complexas, com participação social, perspectiva intersetorial e temporalidade longitudinal (BYDLOWSKI; WESTPHAL; PEREIRA, 2004). Foram raros os estudos sobre o PSE enquanto estratégia promotora da saúde orientada em princípios tais como democracia, participação social, empoderamento, equidade, concepção holística, intersetorialidade e sustentabilidade, ou que abordem a formação e a atuação profissional a partir de competências para ações multi-estratégicas que congreguem o entorno escolar com o currículo, com o intuito de fortalecer as escolas promotoras da saúde.

\section{Os modelos de formação em Educação Física}

Se a produção de saberes ainda encontra-se pauta no olhar positivista, consideramos relevante superar a visão dicotômica de mundo e avançarmos na direção de abordagens complexas voltadas para a coletividade (MORIN, 2007). O fato de que a escola se constituir 
como ambiente institucional privilegiado para a junção da educação e da saúde, por sua característica de espaço, de convivência social, e de relações favoráveis para ações de Promoção da Saúde, através de uma educação integral, agrega uma importante demanda do PSE aos profissionais que estudam e atuam nesse cenário (BRASIL, 2009). É fundamental suprir a demanda no quesito formação em Promoção da Saúde e realizar encontros e espaços de debate com a comunidade escolar sobre o tema e demais conteúdos que envolvem este movimento teórico (TUSSET, 2012).

Nesse sentido, fazer uma reflexão em torno das questões da Promoção da Saúde na Educação Física escolar por meio de um olhar ampliado, que ultrapasse o plano unicausal da ideia de que a atividade física gera saúde, significa compreender a relação histórica da conformação do campo científico e superar seus paradigmas dominantes. A trajetória curricular da saúde na Educação Física se relaciona à influência de diferentes áreas: a militar, a médica, a esportiva e a da aptidão física (KUNZ, 1991; BRACHT, 2000; FERREIRA, 2001)

Os modelos teóricos de Saúde na Escola também seguem um caminho similar passando por diferentes períodos: o Higienista, o Biomédico especializado, o de uso do espaço da escola para equipamentos e serviços de saúde, e o de Promoção da Saúde (SILVA; BODSTEIN, 2016). Segundos os autores, apesar de avanços na temática, a partir de propostas intersetoriais, o discurso da biomedicina continua hegemônico, possuindo um peso considerável no desenho das políticas de saúde e nas concepções de educação.

O desconhecimento do significado da Promoção da Saúde em uma perspectiva ampliada destaca-se como primeiro obstáculo para implementar ações com essa visão na escola. A abordagem de "educação bancária", baseada na transmissão de informações em que um emissor ativo deve fazer "depósitos de conhecimento" no receptor passivo dessa estratégia, desenvolvida no século XVIII ainda se mantem prevalente (FIGUEIREDO; RODRIGUES-NETO; LEITE, 2009).

O debate em torno das estratégias de mudança nas ações de educação e saúde contempla, em alguma medida, a preocupação com a necessária adaptação à heterogeneidade estrutural que caracteriza as situações de vida da população, especialmente as desigualdades sociais e epidemiológicas que se observam nas diversas regiões do país (TEIXEIRA, 2006).

Consideramos que é de suma importância a formação em saúde tanto a nível inicial (graduação) quanto na formação continuada (serviço) a Promoção da Saúde seja contextualizada em processos de capacitações permanentes. 
Nessa perspectiva o Programa Nacional de Reorientação da Formação Profissional em Saúde reconhece que a conexão entre a esfera do trabalho e da educação implica na ampliação do conceito de saúde. Considera que as interfaces e a riqueza de valores e processos, somados à diversidade de olhares e subjetividades do complexo sistema (serviço, comunidade e universidade), é pautado na busca da transição de um modelo de atenção voltado para Promoção da Saúde (BRASIL, 2007c).

No entanto, a inserção da Educação Física em programas de reformulação da formação profissional é recente e acontece de forma lenta, onde grande parte dos currículos acadêmicos dos cursos de Educação Física no Brasil ainda não contemplam as demandas do novo modelo de formação tendo como base a Atenção Primária à Saúde nem os princípios do SUS (SANTOS et al., 2011). Inclusive, as definições ou indefinições da formação em Educação Física encontra-se em plena discussão atualmente na qual vem sendo colocada em pauta a unificação do curso baseada em uma formação ampliada ou pela continuidade de uma formação dividida em bacharelado e licenciatura.

A saúde é um campo de investigação ou objeto de estudo de natureza imprecisa e não-linear. Essa complexidade resulta na necessidade de diálogo entre áreas e subáreas. Nesse sentido, os profissionais, estudantes, gestores do ensino e do serviço e pesquisadores da Educação Física precisam desenvolver outras formas de se pensar, ensinar e intervir em saúde - com ênfase no coletivo, no público e no social - sem romper com os saberes e práticas já acumulados, de modo que quaisquer tensões sejam saudáveis à medida que os "encontros" entre as fronteiras do conhecimento produzam condições de saúde e de vida melhores para as populações (CARVALHO, 2005).

A busca por uma aproximação da Educação Física com as tendências epistemológicas da Promoção da Saúde e da Saúde Coletiva se faz necessária por possibilitar agregar princípios e valores na discussão do processo sobre a concepção de saúde ampliada elencando críticas relacionadas às práticas e intervenções restritas a uma visão estritamente biológica do movimento humano (OLIVEIRA; MARTINS; BRACHT, 2015).

Estudo sobre a evolução dos conceitos, das práticas e da institucionalização da Promoção da Saúde, na perspectiva da educação para gestores, profissionais e usuários de 17 Centros de Saúde Escola do Brasil identificou a necessidade de se criar e fortalecer as estratégias na compreensão e operacionalização das propostas da Promoção da Saúde, de enfrentamento da questão social, dos determinantes sociais de saúde, e da reorientação dos serviços e da formação profissional, e citam o movimento de Promoção da Saúde como um 
marco histórico por trazer à tona o conceito ampliado sobre as práticas de saúde no mundo globalizado contemporâneo (REIS; SILVA; WONG-UM, 2014).

O próprio PSE indica, em suas normativas, que a operacionalização do Programa deve ocorrer baseada em eixos de ações, agrupados em componentes, dentre os quais se encontram as iniciativas de educação, formação e capacitação em saúde (BRASIL, 2007a). No entanto, conforme aponta, Ferreira et al. (2014), são poucos os avanços registrados no processo de formação permanente e continuada em direção às temáticas relacionadas à Promoção da Saúde no PSE.

A viabilização da formação em Promoção da Saúde deve acontecer a partir de metodologias ativas de forma a estimular à participação da comunidade escolar na construção das ações e atividades voltadas para as reais necessidades do entorno (GOMES, 2012; SILVA JÚNIOR, 2014). Uma possibilidade interessante é adotar a Teoria Construtivista como referencial que considera os saberes e a participação de todas as partes interessadas no processo de ensino-aprendizagem, e destaca a importância do processo transformador das condições de existência e não necessariamente, das condutas individuais (FREIRE, 1997).

Outra estratégia para aprimorar o trabalho em Promoção da Saúde é através do desenvolvimento de competências adaptadas para os contextos e capacidades locais, como uma ferramenta que possa abordar e intervir em educação e em saúde, incluindo rotinas efetivamente intersetoriais, com ampla e equânime participação de pesquisadores, gestores, profissionais da saúde e da educação, jovens, e toda a comunidade, em especial a escolar na construção de práticas ampliadas e inovadoras de Promoção da Saúde (TUSSET et al., 2015).

É necessário adotar, tanto na atenção básica quanto no ambiente escolar, uma perspectiva crítica que estabeleça um marco epistemológico no processo de produção do conhecimento e de formação profissional (CARVALHO; NOGUEIRA, 2016). Os autores chamam a atenção, por exemplo, para uso dos termos "Promoção da Saúde" ou "prevenção de doenças", e "atividade física" ou "práticas corporais" no cotidiano leigo, científico e/ou político como se fossem sinônimos.

Tal problemática precisa ser discutida a partir de referenciais da Saúde Coletiva em aproximação com elementos da Educação Física, em particular os afeitos às Ciências Sociais e Humanas (MEZZAROBA, 2012; NOGUEIRA; BOSI, 2016). Diante do exposto consideramos pertinente apontar confusões nas concepções vigentes dos professores de Educação Física quanto à Promoção da Saúde, de forma a possibilitar reflexões e uma mudança de paradigma, saindo do modelo patogênico em direção à salutogenia. 


\section{Limitações da presente pesquisa}

Alguns aspectos representaram limitações no percurso da presente pesquisa. Um primeiro aspecto refere-se à formação em Educação Física da própria pesquisadora. A pouca experiência tanto teórica quanto prática com a perspectiva das Ciências Sociais e Humanas em saúde e consequentemente, com a metodologia qualitativa de pesquisa, adicionada ao tempo limitado de dois anos para a realização da mesma limitou teórica e metodologicamente a exploração sobre o tema.

A elaboração e a realização das entrevistas também foram afetadas pela pouca experiência da pesquisadora, fazendo com que alguns tópicos relevantes tenham ficado de fora da conversa, tais como: se a formação em Educação Física dos professores participantes era licenciatura e/ou bacharelado; e se a mesma foi realizada em Instituição de Ensino Superior pública ou privada.

Fatores externos como a greve de professores das escolas públicas do DF deflagrada em pleno período de coleta de informações e a crise política Brasileira a partir das eleições de 2014 e acirrada em 2015 e 2016 dificultou o acesso a algumas informações uma vez que o PSE se constitui como uma política pública de âmbito federal. A dificuldade de transporte público e acesso físico a algumas escolas, devido à localização periférica e em algumas áreas de risco também foi uma realidade encontrada pela pesquisadora.

Outra dificuldade se refere à própria extensão e amplitude dos temas da Promoção da Saúde e do PSE, o que resulta numa escassez de estudos similares. Em adição, diversos estudos encontrados também apresentaram limitações relacionadas à qualidade em pesquisa qualitativa, prejudicando o desenvolvimento de uma discussão teórica mais robusta.

No entanto, consideramos que os resultados da pesquisa são satisfatórios para um primeiro contato teórico com o tema da Promoção da Saúde e da metodologia qualitativa em pesquisa. As limitações dessa primeira experiência serviram de aprendizado para os próximos passos. Como desafios posso apontar: melhorar a postura de aproximação com os professores de Educação Física considerando as limitações e possibilidades que caracterizam o contexto no qual estão envolvidos; propor intervenções significativas a partir das necessidades concretas da realidade local; ter como orientação metodológica a pesquisa ação ou a pesquisa participativa baseadas na metodologia de Paulo Freire; e aprofundar o aporte teórico de Edgar 
Morin sobre a "Teoria da Complexidade" (2007) e "Os sete saberes necessários à educação do futuro" (2011); desenvolvendo assim um saber mais sensível e humano. 


\section{CONSIDERAÇÕES FINAIS}

Os apontamentos da presente pesquisa de mestrado estiveram pautados nas percepções de onze professores de Educação Física de seis escolas da rede pública de ensino básico do DF que aderiram ao PSE nos anos de 2014 e 2015, a respeito das relações das práticas corporais ou atividades físicas em um contexto de Promoção da Saúde, o PSE.

Ao identificarmos as perspectivas dos professores de Educação Física escolar sobre um dos núcleos de saber que subsidiam suas práticas pedagógicas, no caso as práticas corporais e atividades físicas e suas relações com a Promoção da Saúde, identificamos um enorme desconhecimento teórico (conceitual) e político (referente às políticas e programas institucionais) sobre esses temas.

Indicando certa alienação, embora reconheçamos também as falhas de comunicação e gestão, os professores de Educação Física entrevistados desconhecem o PSE e sua institucionalização na escola na qual atuam. A similaridade das concepções apresentadas com as convicções hegemônicas historicamente imbuídas nos contextos teóricos e práticos da Educação Física nos sinalizam que a formação profissional do século XXI continua centrada na visão positivista de mundo e biológica de corpo e de saúde, sendo recentemente fortalecidas as dimensões persecutórias, individualistas e de mercado para as atividades físicas em saúde.

A formação fundamentada em teorias sociais e humanas tem sido colocada à margem das discussões em saúde dificultando que esses professores reconheçam aspectos gerais e amplos da conjuntura que condicionam e determinam o se movimentar, o agir e o ser saudável. Não obstante, podemos reconhecer a presença de alguns elementos, ainda que incipientes e escassos, que remetem a uma visão mais ampliada de Promoção da Saúde, em geral numa perspectiva de Educação em Saúde.

É importante repensar as dinâmicas, modelos e processos para o fortalecimento da participação e do desenvolvimento nas ações das escolas, de forma mais articulada e sustentável com investimento em infraestrutura e foco na formação no âmbito da educação em saúde. Talvez seja essa a estratégia mais viável no momento para que os desafios que permeiam a efetiva operacionalização de práticas de Promoção da Saúde na escola sejam superados. Nessa direção apontamos a necessidade premente da reformulação das formações em saúde, em especial da Educação Física, de forma a incorporar os referenciais da Promoção da Saúde, dos Determinantes Sociais e da Saúde Coletiva nos cursos superiores da área. 
Em síntese, propomos como sugestões para a gestão do PSE no DF uma análise avaliativa do programa, com métodos qualitativos, ampliados por meio de consultas nas escolas com o intuito de identificar as opiniões da comunidade escolar, sobretudo dos professores de Educação Física a respeito do PSE. É importante que aconteça uma ampla apresentação do programa e ênfase no processo de sensibilizar toda a comunidade escolar a envolver-se no desenvolvimento das ações do PSE. A formação dos profissionais tanto da saúde quanto da educação (incluindo-se aí os professores) por meio de capacitação participativa e com a elaboração de atividades norteadas tendo como base o referencial teórico da Promoção da Saúde pode ser uma boa estratégia para dar início no andamento das ações do PSE. A partir da capacitação participativa poderiam ser elaboradas atividades, organizadas por meio de um calendário, que seriam colocadas em prática durante o ano letivo da escola baseadas no que foi entendido na capacitação.

Um fator determinante é a necessidade do diálogo e empenho constante entre os profissionais da saúde e educação. Sugerimos a elaboração de uma estratégia metodológica entre esses profissionais no processo de sensibilizar os envolvidos para maior integração e participação nas ações do programa. A participação social é peça essencial para que o andamento do PSE aconteça.

Aos professores e demais profissionais que estão na escola sugerimos uma maior sensibilização e motivação no que diz respeito ao programa. O PSE precisa ser entendido como uma ferramenta complementar no processo de educação e desenvolvimentos dos alunos. Os professores podem contribuir fundamentalmente no processo de interligar os temas das suas disciplinas no processo do cuidado em saúde (de Promoção da Saúde), por meio de atividades interdisciplinares.

Ao meio acadêmico científico que tem como objeto de estudo o PSE, sugerimos a continuidade das pesquisas sobre o programa e que o âmbito das investigações leve em consideração o contexto social que se encontra o PSE e o reconhecimento das peculiaridades dos envolvidos no programa.

É de suma importância que aconteça o envolvimento conjunto dos atores sociais para que o PSE se concretize como ferramenta estruturada para melhoria da qualidade de vida das crianças e adolescentes. Nesse sentido, o movimento da Promoção da Saúde dar indícios de como podemos trabalhar coletivamente e trilhar bons caminhos nesse processo de produção de saúde por meio da participação social e empoderamento dos sujeitos. 


\section{PERSPECTIVAS FUTURAS}

No curso do caminho percorrido, talvez tenhamos acumulado mais inquietações do que respostas. A complexidade e a amplitude do fenômeno da Promoção da Saúde, do contexto escolar e do sistema de saúde público abrem uma gama de possibilidades investigativas, todas extremamente pertinentes e necessárias. Investigar as aproximações das práticas corporais ou atividades físicas no contexto educacional com o movimento da Promoção da Saúde através do PSE foi desafiador e, de várias formas, inquietante.

O quase completo desconhecimento por parte dos professores de Educação Física sobre o PSE foi uma das maiores preocupações. Como investigar um fenômeno se as pessoas não o conhecem? Mas foi também uma oportunidade para elencarmos uma série de reflexões e possibilidades de continuidade dos estudos norteadores da presente pesquisa.

Alguns questionamentos derivados dessas reflexões são: como fazer com que a saúde na escola se torne algo legitimado por toda a comunidade escolar; como ampliar os papéis de lideranças nesse processos, aproveitando a conjunção educação e saúde que perpassa o campo da Educação Física e incluindo o protagonismo juvenil; como deslocar a perspectiva e o foco das ações da esfera individual para os macrodeterminantes; dentre tantos outros.

Em nossa percepção, as respostas para todas essas questões passam, de uma forma ou de outra, pela formação e o desenvolvimento de competências adaptadas para a formação em Promoção da Saúde. Há que se investir nas pedagogias mais participativas e reformular o modo de pensar linear, dual e simplificador da ciência tradicional, abrindo novas possibilidades de olhares complexos e de religação com o todo.

Percebemos que o desafio é muito maior do que o que esperávamos. Falta motivação, falta conhecimento, falta comunicação, gestão e estrutura adequadas nas escolas e nos programas lá desenvolvidos. Mas tamanhas lacunas nos dão uma certeza: é impossível retroceder; temos que avançar!

Com esta certeza seguiremos buscando fundamentar as práticas de intervenção e de pesquisa no campo da Educação Física a partir desses referenciais mais modernos. Por onde passarmos, deixaremos plantada a semente que sobrepuja a visão da prática da atividade física para o gasto calórico e dissemina o olhar para os Determinantes Sociais do fenômeno. "É preciso ter força, é preciso ter raça; é preciso ter gana sempre...”. Sigamos! 


\section{REFERÊNCIAS BIBLIOGRÁFICAS}

1. ABRASCO. Promoção da Saúde - resgate histórico. Disponível em:

$<$ https://www.abrasco.org.br/site/2015/02/abrasco-e-curitiba-preparam-a-22a-conferenciamundial-de-promocao-da-saude/>. Acesso em: 01 jun. 2016.

2. AERTS, Denise et al. Promoção de saúde: a convergência entre as propostas da vigilância da saúde e da escola cidadã Health promotion: convergence between the principles of health surveillance. Cadernos de Saúde Pública, v. 20, n. 4, p. 1020-1028, 2004.

3. ALBUQUERQUE, Débora Lima Barbosa de; MENEZES, Cristiane Souza de. Educação Alimentar na Escola: Em busca de uma vida saudável. p. 1-25, 2010.

4. ANJOS, Tatiana Coletto dos; DUARTE, Ana Cláudia Garcia de Oliveira. A Educação Física e a Estratégia de Saúde da Família: formação e atuação profissional. Physis (Rio J.), v. 19, n. 4, p. 1127-1144, 2009.

5. ANUÁRIO DO DISTRITO FEDERAL. 2014: uma ferramenta de fomento ao turismo e ao desenvolvimento do Distrito Federal / Mark Comunicação, Ano 5, nº 1, agosto 2014, Brasília, 2014.

6. ARAUJO, Raffaelle e SANTOS, Andressa dos. A Educação Física na formação inicial: prática pedagógica e currículo. São Luís/MA. EDUFMA, 2014.

7. ASSIS, Sheila Soares de et al. Conhecimentos e práticas educativas sobre dengue: a perspectiva de professores e profissionais de saúde. Ensaio Pesquisa em Educação em Ciências (Belo Horizonte), v. 15, n. 1, p. 131-153, 2013.

8. ASSIS, Sheila Soares de; JORGE, Tania Araújo. As doenças negligenciadas e a promoção da saúde: possibilidades e limites para a articulação entre os currículos de ciências e o Programa Saúde na Escola (PSE). Revista da SBEnBio, v. 5, n. 7, p. 6853-6864, 2014.

9. BAGRICHEVSKY, Marcos. A formação profissional em educação física enseja perspectivas (críticas) para atuação em saúde coletiva?. In: FRAGA, A. B.; WACHS, F. Educação Física e saúde coletiva: políticas de formação e perspectivas de intervenção. Porto Alegre: Ed. da UFRS, 2007.

10. BARBIERI, Aline Fabiane. Análise de políticas públicas brasileiras de educação e saúde na escola no contexto de crise estrutural do capital: a função social do Programa Saúde na Escola. 2014. 245 f. Dissertação (Mestrado) - Programa de Pós-graduação em Educação, Centro de Ciências Humanas, Letras e Artes, Universidade Estadual de Maringá, Maringá, 2014.

11. BARDIN, L. Análise de conteúdo. São Paulo, SP: Edições 70, 2007. 279 p.

12. BARRY, Margaret M. et al. The Galway Consensus Conference: international collaboration on the development of core competencies for health promotion and health. Global Health Promotion, [s.1.], v. 16, n. 2, p.05-11, 15 maio 2009. 
13. BAUMAN, A.F. Updating the evidence that physical activity is good for health: an epidemiological review 2000-2003. Journal of Science and Medicine in Sport 2004;7(1 Suppl):6-19.

14. BAUMAN, Zygmunt. Modernidade líquida. Rio de Janeiro: Jorge Zahar, 2001.

15. BETTI, Mauro et al. A avaliação da educação física em debate: implicações para a subárea pedagógica e sociocultural. Revista Brasileira de Pós-Graduação, v. 1, n. 2, 2004.

16. Mauro et al. Fundamentos filosóficos e antropológicos da Teoria do Semovimentar e a formação de sujeitos emancipados, autônomos e críticos: o exemplo do currículo de Educação Física do Estado de São Paulo. Movimento, p. 1631-1653, 2014.

17. BETTI, Mauro; ZULIANI, Luiz Roberto. Educação física escolar: uma proposta de diretrizes pedagógicas. Revista Mackenzie de Educação Física e Esporte, v. 1, n. 1, 2002.

18. BODSTEIN, Regina. The complexity of the discussion on effectiveness and evidence in health promotion practices. Promotion \& Education, v. 14, n. 1 suppl, p. 16-20, 2007.

19. BOLZAN, Doris Pires Vargas; MILLANI, Silvana Martins de Freitas. Docência e Formação: reflexões sobre a gestão pedagógica na escola. Políticas Educativas, v. 4, n. 2.

20. BOURDIEU, Pierre. O campo científico. In: Ortiz R. organizador. Pierre Bourdieu: Sociologia. São Paulo: Ática; 1983. p.122-55.

21. BRACHT, Valter. A constituição das teorias pedagógicas da educação física. Cadernos Cedes, v. 19, n. 48, p. 69-88, 1999.

22. . Educação Física e Ciência: cenas de um casamento (in) feliz. Rev. Bras. Cienc. Esporte. 2000; 22(1):53-65.

23. BRANDÃO, Roberto Eduardo Albino. A implementação do Programa Saúde na Escola no território de Manguinhos (RJ): estratégias de privatização na política pública. 2014. 144 f. Dissertação (Mestrado) - Mestrado Profissional em Educação Profissional em Saúde, Escola Politécnica de Saúde Joaquim Venâncio, Fundação Oswaldo Cruz, Rio de Janeiro, 2014.

24. BRASIL. Senado Federal. Lei de diretrizes e bases da educação nacional. Ministério da Educação, Brasília, 1996.

25. A promoção da saúde no contexto escolar. Informes técnicos institucionais. Revista de Saúde Pública, v. 36, n. 2, p. 533-5, 2002.(a).

26. Coordenação geral de alimentação e nutrição. Programa Saúde na Escola (PSE): Desafios da Intersetorialidade. Apresentação institucional. Fortaleza. 2012. 28 slides, color. Disponível em: <http://www.itarget.com.br/newclients/undimece.org.br/2011/extra/download/Apresentacao.pdf>. Acesso em: 04 dez. 2015.

27. Decreto $n^{\circ}$ 6286, de 5 de dezembro de 2007. Institui o Programa Saúde na Escola. Brasília, DF, 5 dez. 2007. Disponível em: 
<http://www.planalto.gov.br/ccivil_03/_ato2007-2010/2007/decreto/d6286.htm>. Acesso em: 14 out. 2014.

28. Ministério da Educação. Conselho Nacional de Educação. Câmara de Educação Superior. Resolução CNE/CES n 07, de 31 de março de 2004. Institui as Diretrizes Curriculares Nacionais para os cursos de graduação em Educação Física, em nível superior de graduação plena. Diário Oficial da União 2004; 31 mar.(b)

29. . Ministério da Saúde. Conselho Nacional de Saúde. Resolução no 218, de 6 de Março de 1997. Reconhece profissões da área da saúde. Diário Oficial da União 1997; 06 mar.

30. Ministério da Saúde. Política Nacional de Promoção da Saúde (PNPS), Brasília, 2014, disponível em: http://bvsms.saude.gov.br/bvs/saudelegis/gm/2014/prt2446_11_11_2014.html. acessado em: abril/2015. (a)

31. . Ministério da Saúde. Política Nacional de Promoção da Saúde (PNPS). Secretaria de Vigilância em Saúde, Brasília, v. 7, 2006.

32. Ministério da Saúde. Secretaria de Atenção à Saúde. Departamento de Atenção Básica. Saúde na escola. Brasília, DF: Ministério da Saúde, 2009a. 96 p. (Série B. Textos Básicos de Saúde. Cadernos de Atenção Básica, n. 24)

33. Passo a passo PSE: Programa Saúde na Escola, tecendo caminhos da intersetorialidade. Ministério da Saúde. Secretaria de Atenção à Saúde. Departamento de Atenção Básica. Ministério da Educação. Brasília, DF: Ministério da Saúde, 2011, 46 p.

34. Secretaria de Atenção à Saúde. Departamento de Atenção Básica. Caderno temático: práticas corporais, atividade física e lazer (versão preliminar), 2015. Disponível em: http://189.28.128.100/dab/docs/portaldab/documento/caderno_praticas_ corporais_atividade-fisica_lazer.pdf. Acessado em abril/2015.

35. Secretaria de Educação Fundamental. Parâmetros Curriculares Nacionais: Educação Física. Brasília, DF: MEC, 1998. Disponível em: <http://portal.mec.gov.br/seb/arquivos/pdf/ fisica.pdf>. Acesso em: 18 out. 2015.

36. Ministério da Educação. Portaria Normativa Interministerial nº17, de 24 de abril de 2007. Institui o Programa Mais Educação que visa fomentar a educação integral de crianças, adolescentes e jovens, por meio do apoio a atividades socioeducativas no contraturno escolar. Disponível em: http://portal.mec.gov.br/programamais-educacao. Acesso em: 19 out. de 2015. $2007 \mathrm{~b}$.

37. Ministério da Saúde. As cartas de promoção à saúde. Brasília, 2002.

38. Departamento de Atenção Básica. Semana Saúde na Escola de 2014.

Disponível em: 〈http://dab.saude.gov.br/portaldab/pse.php?conteudo=saiba_mais>. Acesso em: 12 jan. 2016. (b). 
39. Ministério da Educação (MEC). Conselho Nacional de Educação (CNE).

Conselho Pleno. Parecer n. 009, de 8 de maio de 2001. Diretrizes Curriculares Nacionais para a Formação de Professores da Educação Básica, em nível superior, curso de licenciatura, de graduação plena. Brasília, 2001.

40. . Ministério da Saúde. Ministério da Educação. Programa Nacional de

Reorientação da Formação Profissional em Saúde - Pró-Saúde : objetivos, implementação e desenvolvimento potencial / Ministério da Saúde, Ministério da Educação. Brasília: Ministério da Saúde, 2007(c).

41. BREILH, Jaime. La Camisa de Fuerza de las Categorías Empíricas: "Riesgo", “Carga" y "Daño". [S.I.],1997.

42. BRITO, Camila; OLIVEIRA, Marluce. Bullying and self-esteem in adolescents from public schools. Jornal de Pediatria, v. 89, n. 6, p. 601-607, 2013.

43. BUSS, Paulo Marchiori et al. Promoção da saúde e qualidade de vida. Ciência \& saúde coletiva, v. 5, n. 1, p. 163-177, 2000.

44. BUSS, Paulo Marchiori; CARVALHO, Antonio Ivo de. Desenvolvimento da promoção da saúde no Brasil nos últimos vinte anos (1988-2008). Ciência \& saúde coletiva, Rio de Janeiro,v. 14, n. 6, p. 2305-2316, Dec. 2009.

45. BUSS, Paulo Marchiori; PELLEGRINI FILHO, Alberto. A saúde e seus determinantes sociais. Physis, v. 17, n. 1, p.77-93, abr. 2007.

46. BUSS, Paulo Marchiori; FERREIRA, José Roberto. Atenção primária e promoção da saúde. Ministério da Saúde. As cartas da promoção da saúde. Brasília: Ministério da Saúde, 2000 .

47. BYDLOWSKI, Cynthia Rachid; WESTPHAL, Márcia Faria; PEREIRA, Isabel Maria Teixeira Bicudo. Promoção da Saúde. Porque sim e porque ainda não!. Saúde e Sociedade, v. 13, n. 1, p. 14-24, 2004.

48. CAMARGO, Tatiana Souza de. O governo dos excessos: uma análise das práticas de prevenção e controle do excesso de peso realizadas por profissionais da Atenção Básica à Saúde, em Porto Alegre/RS. 2012. 176 f. Tese (Doutorado) - Curso de Educação, Universidade Federal do Rio Grande do Sul, Porto Alegre, 2012.

49. CANDEIAS, Nelley Martins Ferreira. Conceitos de educação e de promoção em saúde: mudanças individuais e mudanças organizacionais. Revista de Saúde Pública, v.31, n.2, p. 209-13, 1997.

50. CANEL, Regina Célia; DE CASTRO, Cláudio Gastão Junqueira. A advocacia em saúde como uma estratégia para a promoção da saúde. Revista de Direito Sanitário, v. 9, n. 1, p. 74-85, 2008.

51. CARDOSO, Gustavo Marques Porto. Vida Universitária, Atividade Física e Promoção da Saúde entre estudantes da Universidade Federal da Bahia. 2015. 135 f. 
Dissertação (Mestrado) - Curso de Estudos Interdisciplinares, Programa de Pós-graduação em Estudos Interdisciplinares, Universidade Federal da Bahia, Savaldor, 2015.

52. CARDOSO, Vanessa; REIS, Ana Paula dos; IERVOLINO, Solange Abrocesi. Escolas Promotoras de Saúde. Revista brasileira de crescimento e desenvolvimento humano. 2008; 18(2): 107-115.

53. CARGNIN, Miria Trentin. Programa Saúde na Escola: uma estratégia de governamento. 2015. 191 f. Tese (Doutorado) - Programa de Pós-graduação em Educação nível doutorado, Unidade Acadêmica de Pesquisa e Pós-graduação, Universidade do Vale do Rio dos Sinos - Unisinos, São Leopoldo/RS, 2015.

54. CARVALHO, Fabio Fortunato Brasil de; NOGUEIRA, Júlia Aparecida Devidé. Práticas corporais e atividades físicas na perspectiva da Promoção da Saúde na Atenção Básica. Ciência \& Saúde Coletiva, v. 21, n. 6, p. 1829-1838, 2016.

55. CARVALHO, Fábio Fortunato Brasil. Atividade física na perspectiva crítica de promoção da saúde: por outra compreensão da Educação Física. 64 f. Trabalho de conclusão do curso (Especialização) - Escola Nacional de Saúde Pública Sérgio Arouca, Fundação Oswaldo Cruz, Rio de Janeiro, 2008.

56. Educação física e saúde coletiva-diálogo e aproximação. Corpus et Scientia, v. 8, n. 3, p. 109-126, 2012(a).

57. . A saúde na escola e a Promoção da Saúde: conhecendo a dinâmica intersetorial em Duque de Caxias e Nova Iguaçu - RJ. 2012. 115 f. Dissertação (Mestrado) Curso de Ciências na área de Saúde Pública, Departamento de Ciências Sociais., Escola Nacional de Saúde Pública Sérgio Arouca, Rio de Janeiro, 2012(b).

58. CARVALHO, Sérgio Resende; GASTALDO, Denise. Promoção à saúde e empoderamento: uma reflexão a partir das perspectivas crítico-social pósestruturalista. Ciência \& saúde coletiva, v. 13, p.2029-2040, dez. 2008.

59. CARVALHO, Yara Maria de. Entre o biológico e o social. Tensões no debate teórico acerca da saúde na Educação Física. Motrivivência, n. 24, p. 97-106, 2005.

60. CASEMIRO, Juliana Pereira; FONSECA, Alexandre Brasil Carvalho da; SECCO, Fabio Vellozo Martins. Promoting health in school: reflections based on a review of school health in Latin America. Ciência \& Saúde Coletiva, v. 19, n. 3, p. 829-840, 2014.

61. CASTELLANI FILHO, Lino. A Educação Física no sistema educacional brasileiro: percurso, paradoxos e perspectivas. Tese (Doutorado). Universidade Federal de Campinas. Campinas, 1999. 185 f. Programa de Pós-Graduação da Faculdade de Educação, 1999.

62. CAVALCANTI, Patricia Barreto et al. Programa Saúde na Escola: interpelações sobre ações de educação e saúde no Brasil / Program Health in the School: interpellations on action of education and health in Brazil. Textos \& Contextos (Porto Alegre), v. 14, n. 2, p. 387, 2015. 
63. CERQUEIRA, Maria Teresa. Construção da Rede Latino Americana de Escolas Promotoras de Saúde. In: BRASIL. Ministério da Saúde. Organização Pan-Americana da Saúde.

64. CHRISTMANN, Morgana; PAVÃO, Silvia Maria de Oliveira. A saúde do escolar cuidada por práticas governamentais : reflexos para a aprendizagem. Revista de Educação PUC-Campinas, v. 20, n. 3, p. 265-277, [s.d.].

65. CIRQUEIRA, Denise Soares de. Estudo do perfil antropométrico, estilo de vida e comportamento sexual de adolescentes do Programa Saúde na Escola. 2014. 75 f.

Dissertação (Mestrado) - Programa de Pós-graduação em Saúde Coletiva, Núcleo de Estudos em Saúde Coletiva, Universidade Federal de Goiás, Goiânia, 2014.

66. CODEPLAN. Pesquisa Distrital por Amostra de Domicílios 2013-2015. Disponível em: http://www.codeplan.df.gov.br/component/content/article/261-pesquisassocioeconomicas/295-pesquisa-distrital-por-amostra-de-domicilios-.html\#. Acesso em $\mathrm{abril} / 2016$.

67. CORD, Denise et al. As Significações de Profissionais que Atuam no Programa Saúde na Escola (PSE) Acerca das Dificuldades de Aprendizagem: Patologização e Medicalização do Fracasso Escolar. Psicologia: Ciência e Profissão, v. 35, n. 1, p. 40-53, 2015.

68. COSTA, Lamartine da. Atlas do esporte no Brasil. Organizador. Rio de Janeiro: CONFEF, 2006.

69. COSTA, Roosevelt Rodrigues da. O Programa Saúde na Escola: análise da implementação de uma política pública de educação. 2013. 99 f. Dissertação (Mestrado) Mestrado em Educação, Núcleo de Pós-graduação em Educação, Universidade Federal de Sergipe, São Cristóvão (SE), 2013.

70. CZERESNIA, Dina. O conceito de saúde e a diferença entre prevenção e promoção. Promoção da saúde: conceitos, reflexões, tendências, v. 3, p. 39-54, 2003.

71. DEMPSEY, C.; BARRY, M.; BATTEL-KIRK, B. Literature review developing Competencies for Health Promotion Deliverable 3B. Executive Agency for Health Promotion and Consumers and National University of Ireland Galway. Dispível em: <http://www.iuhpeorguploaded/Activities/Cap_building/CompHP/CompHP_LiteratureRevie wPArt1.pdf> Acesso em: 14 fev. 2015.

72. DIAS, Maria Socorro de Araújo et al. Programa Saúde na Escola: tecendo uma análise nos documentos oficiais. SANARE-Revista de Políticas Públicas, v. 13, n. 1, 2014.

\section{DISTRITO FEDERAL. Promovendo Saúde na Escola: Implantação do Programa} Saúde na Escola no Distrito Federal. 2009.

74. FARIAS, Isabelle Carolline VerÍssimo de. Análise da intersetorialidade no Programa Saúde na Escola no município de Olinda-PE: perspectivas da saúde e da educação. 2014. 98 f. Dissertação (Mestrado) - Programa de Pós-graduação Integrado em Saúde Coletiva, Centro de Ciências da Saúde, Universidade Federal de Pernambuco, Recife, 2014. 
75. FELIX, Wendel. O Programa Saúde na Escola em escolas municipais de

Uberlândia - MG. 2013. 171 f. Dissertação (Mestrado) - Programa de Pós-graduação em Geografia, Instituto de Geografia, Universidade Federal de Uberlândia, Uberlândia/Minas Gerais, 2013.

76. FERREIRA, Heraldo Simões; OLIVEIRA, Braulio Nogueira de; SAMPAIO, José Jackson Coelho. Análise da percepção dos professores de Educação Física acerca da interface entre a saúde e a Educação Física escolar: conceitos e metodologias. Revista Brasileira de Ciências do Esporte, v. 35, n. 3, 2013.

77. FERREIRA, Izabel do Rocio Costa et al. Diplomas Normativos do Programa Saúde na Escola: análise de conteúdo associada à ferramenta ATLAS TI. Ciência \& Saúde Coletiva, v. 17, n. 12, p. 3385-3398, 2012.

78. FERREIRA, Izabel do Rocio Costa et al. Percepções de gestores locais sobre a intersetorialidade no Programa Saúde na Escola. Revista Brasileira de Educação, n. 1, 2014.

79. FERREIRA, Marcos Santos et al. Atividade física na perspectiva da Nova Promoção da Saúde: contradições de um programa institucional. Ciência \& saúde coletiva, v. 16, n. Supl 1, p. 865-72, 2011.

80. FERREIRA, Marcos Santos. Aptidão Física e Saúde na Educação Física escolar: ampliando o enfoque. Revista Brasileira de Ciências do Esporte, Campinas, v. 22, n. 2, p.41-54, 2001. Disponível em: <http://revista.cbce.org.br/index.php/RBCE/article/view/411>. Acesso em: 29 set. 2014.

81. FERREIRA, Marcos Santos; CASTIEL, Luis David; CARDOSO, Maria Helena Cabral de Almeida. Atividade física na perspectiva da Nova Promoção da Saúde: contradições de um programa institucional. Ciência \& saúde coletiva, v. 16, p. 865-872, 2011.

82. FIALHO, Alex et al. O imaginário coletivo de estudantes de educação física sobre vida saudável. Revista brasileira de Ciências do Esporte, v. 36, n. 3, p. 626-631, 2014.

83. FIGUEIREDO, Maria Fernanda Santos; RODRIGUES-NETO, João Felício; LEITE, Maísa Tavares Souza. Modelos aplicados às atividades de educação em saúde:[revisão]. Revista brasileira de enfermagem, v. 63, n. 1, p. 117-121, 2010.

84. FIGUEIREDO, Túlio Alberto Martins de; MACHADO, Vera Lúcia Taqueti; ABREU, Margaret Mirian Scherrer de. A saúde na escola: um breve resgate histórico. Ciência \& Saúde Coletiva, v. 15, n. 2, p. 397-402, 2010.

85. FLICK, Uwe. Introdução à pesquisa qualitativa. Coleção Pesquisa Qualitativa (Coordenação de Uwe Flick). Porto Alegre: Bookman, Artmed, 2009.

86. FONSECA, João Pedro. Saúde escolar e educação. Revista da Faculdade de Educação, v. 11, n. 1-2, p. 313-315, 1985.

87. FREIRE Paulo. Pedagogia da autonomia: saberes necessários à prática educativa. São Paulo: Paz e Terra; 1997. 
88. GIACOMOZZI, Andréia Isabel et al. Levantamento sobre uso de álcool e outras drogas e vulnerabilidades relacionadas de estudantes de escolas públicas participantes do programa saúde do escolar/saúde e prevenção nas escolas no município de Florianópolis. Saúde e Sociedade, v. 21, n. 3, p. 612-622, 2012.

89. GODOI, Sirlei Cristina; POL, Pâmela de; MATIA, Graciele de. A inserção da equipe de saúde da família no ambiente escolar público: perspectiva do professor. Cogitare Enfermagem, v. 17, n. 2, 2012.

90. GOMES, Claudia de Moraes; HORTA, Natália de Cássia. Promoção de Saúde do adolescente em âmbito escolar. Revista de Atenção Primária à Saúde, v. 13, n. 4, 2010.

91. GOMES, Lívia Cardoso. O desafio da intersetorialidade: a experiência do Programa Saúde na Escola (PSE) em Manguinhos, no município do Rio de Janeiro. 2012. 173 f. Dissertação (Mestrado) - Ciências, Saúde Pública, Escola Nacional de Saúde Pública Sergio Arouca, Rio de Janeiro, 2012.

92. GONÇALVES, Fernanda Denardin. et. al. A promoção da saúde na educação infantil. Interface Comunicação, Saúde, Educação, v.12, n. 24, p. 181-192, 2008.

93. GONZÁLEZ, Fernando Jaime; FENSTERSEIFER, Paulo Evaldo. Entre o 'Não Mais' e o 'Ainda Não': pensando Saídas do Não-Lugar da Educação Física Escolar I. Cadernos de Formação RBCE, v. 1, p. 9-24, 2009.

94. GRACIANO, Andréa Monteiro de Castro et al. Promoção da Saúde na Escola: história e perspectivas. Journal of Health \& Biological Sciences, v. 3, n. 1, p. 34-38, 2015.

95. HARADA, Jorge et al. Cadernos de Escolas Promotoras de Saúde-I.

96. HEIDMANN, Ivonete TS et al. Health promotion: historic trajectory of its conceptions. Texto \& Contexto-Enfermagem, v. 15, n. 2, p. 352-358, 2006.

97. HONORIO, Renata Félix; HADLER, Maria Claret Costa Monteiro. Factors associated with obesity in brazilian children enrolled in the school health program: a case-control study. Nutricion hospitalaria, v. 30, n. 3, p. 526-534, 2014.

98. HORSBURGH, Dorothy. Evaluation of qualitative research studies. Evid Based Nurs. 2003; 6(1367-6539 (Print)): 36-40.

99. IANNI, Octavio. A questão nacional na América Latina. Estudos Avançados, v. 2, n. 1, p. 5-40, 1988.

100. IPPOLITO-SHEPHERD, J. A promoção da saúde no âmbito escolar: a iniciativa regional escolas promotoras de saúde. In: SOCIEDADE BRASILEIRA DE PEDIATRIA. Escola promotora de saúde. Brasília: Sociedade Brasileira de Pediatria, 2003.

101. IZIDORO, Gabriela da Silva Lourelli et al. A influência do estado nutricional no desempenho escolar. Revista CEFAC, v. 16, n. 5, p. 1541-1547, 2014. 
102. JACÓE, Natália Borges et al. O olhar dos profissionais de uma Unidade Básica de Saúde sobre a implantação do Programa Saúde na Escola. Revista Médica de Minas Gerais, v. 24, n. 1, p. 43-48, 2014.

103. KELLEHER, Cecily. Evaluating health promotion in four key settings. In: DAVIES, John Kenneth; MACDONALD, Gordon, editors. Quality, evidence and effectiveness in health promotion: striving for certainties. London: Routledge; 2001. p. 47-67.

104. KNUTH, Alan; LOCH, Mathias. "Saúde é o que interessa, o resto não tem pressa"? Um ensaio sobre educação física e saúde na escola. Revista brasileira de Atividade Física Saúde, Pelotas, v. 19, n. 4, p.429-440, 31 jul. 2014.

105. KÖPTCKE, Luciana Sepúlveda et al. O olhar de cada um : elementos sobre a construção cotidiana do Programa Saúde na Escola no DF. Tempus - Actas de Saúde Coletiva, v. 9, n. 3, p. 213-232, 2015.

106. KUNZ, Elenor. Educação física: ensino \& mudanças. Ijuí, RS: Ed. da Unijuí, 1991.

107. LAZZAROTTI FILHO, Ari, et al. O termo práticas corporais na literatura científica brasileira e sua repercussão no campo da Educação Física. Movimento (ESEF/UFRGS), v. 16, n. 1, p. 11-29, 2010.

108. LAZZAROTTI FILHO, Ari; SILVA, Ana Márcia; MASCARENHAS, Fernando. Transformações contemporâneas do campo acadêmico-científico da educação física no Brasil: novos habitus, modus operandi e objetos de disputa. Movimento (ESEF/UFRGS), v. 20, n. esp, p. 67-80, 2014.

109. LEITE, Cícero Tavares et al. The school health program: teachers' perceptions. . Investigación y Educación en Enfermería, v. 33, n. 2, p. 280-287, 2015.

110. LIBERAL, Edson Ferreira et al. Escola segura. Jornal de Pediatria, v. 81, n. 5, p. 15563, 2005.

111. LIMA, Homero Luis Alves. Pensamento epistemológico da educação física brasileira: das controvérsias acerca do estatuto científico. Revista brasileira de Ciências do Esporte, v. 21, n. 2, 2010.

112. LOCH, Mathias Roberto. A promoção da atividade física na escola: um difícil e necessário desafio. Revista brasileira de Atividade Física Saúde. 2011;16(1):76-7.

113. LUZ, Madel Terezinha. Educação Física e saúde coletiva: papel estratégico da área e possibilidades quanto ao ensino na graduação e integração na rede de serviços públicos de saúde. In: FRAGA, A. B.; WACHS, F. Educação Física e saúde coletiva: políticas de formação e perspectivas de intervenção. Porto Alegre: Ed. da UFRGS, 2007.

114. MACDONALD, Gordon.; VEEN, C.; TONES, K. Evidence for success in health promotion: suggestions for improvement. Health Education Research, v. 11, n. 3, p. 367376, 1996. 
115. MACHADO, Maria de Fátima Antero Sousa et al. Programa Saúde na Escola: Estratégia Promotora de Saúde na Atenção Básica no Brasil. Journal of Human Growth and Development,v. 25, n. 3, p. 307-312, 2015.

116. MAGALHÃES, Rosana. Avaliação da Política Nacional de Promoção da Saúde: perspectivas e desafios. Ciência \& Saúde Coletiva, v. 21, n. 6, p. 1767-1776, 2016.

117. Constrangimentos e oportunidades para a implementação de iniciativas intersetoriais de promoção da saúde: um estudo de caso. Cadernos de Saúde Pública, v. 31, n. 7, p. 1427-1436, 2015.

118. MALTA, Deborah Carvalho et al. Política Nacional de Promoção da Saúde (PNPS): capítulos de uma caminhada ainda em construção. Ciência \& Saúde Coletiva, v. 21, n. 6, p. 1683-1694, 2016.

119. MALTA, Deborah Carvalho; CASTRO, Adriana Miranda de. Avanços e resultados na implementação da Política Nacional de Promoção da Saúde. Boletim técnico do SENAC, v. 35, p. 63-71, 2009.

120. MALTA, et al. Política Nacional de Promoção da Saúde, descrição da implementação do eixo atividade física e práticas corporais, 2006 a 2014. Revista brasileira de Atividade Física \& Saúde, v. 19, n. 3, p. 286, 2014.

121. MELLO, Ana Lúcia Schaefer Ferreira de; MOYSES, Simone Tetu; MOYSES, Samuel Jorge. A universidade promotora de saúde e as mudanças na formação profissional. Interface-Comunicação, Saúde, Educação, v. 14, n. 34, p. 683-692, Sept. 2010.

122. MENICUCCI, Telma Maria Gonçalves. The health policy in Lula's government. Saúde e Sociedade, v. 20, n. 2, p. 522-532, 2011.

123. MEZZAROBA, Cristiano. Ampliando o olhar sobre saúde na educação física escolar: críticas e possibilidades no diálogo com o tema do meio-ambiente a partir da saúde coletiva. Motrivivência, [s.1.], n. 38, p.231-246, 18 set. 2012.

124. MORETTI, Andrezza C. et al. Práticas Corporais / Atividade Física e Políticas Públicas de Promoção da Saúde Corporal. Saúde e Sociedade, v. 18, n. 2, p. 346-354, 2009.

125. MORIN, Edgar. Introdução ao pensamento complexo. Porto Alegre: Sulina, 2007. 126. Os setes saberes necessários à educação do futuro. Cortez Editora, 2011.

127. MOROSINI, Márcia Valéria; FONSECA, Angélica Ferreira; PEREIRA, Isabel Brasil, Educação em Saúde. Dicionário da Educação Profisssional em Saúde. Fundação Oswaldo Cruz. Escola Politécnica de Saúde Joaquim Venâncio. Acessado em: jan, 2015. Disponível em:http://www.sites.epsjv.fiocruz.br/dicionario/verbetes/edusau.html

128. MOURA, João Batista Vianey Silveira et al. Perspectiva da epistemologia histórica e a escola promotora de saúde. História, Ciências, Saúde-Manguinhos, v. 14, n. 2, p. 489-501, 2007. 
129. NEVES, Tatiana Pereira. Reflexões sobre a promoção da saúde. Revista Espaço Acadêmico, v. 6, n. 62, 2006.

130. NOGUEIRA, Julia Aparecida Devidé. A Educação Física e a Saúde.

Humanidades, Brasília, v. 60, p.102-113, 2014.

131. NOGUEIRA, Julia Aparecida Devidé; BOSI, Maria Lúcia Bosi Malú. Saúde Coletiva e Educação Física: distanciamentos e interfaces. Ciência \& saúde coletiva [periódico na internet] 2016 maio. [Citado em 03 de junho 2016]; [cerca de 8 p.] Está disponível em: http://www.cienciaesaudecoletiva.com.br/ingles/artigos/artigo_int.php?id_artigo=15644

132. OLIVEIRA, Victor José Machado de; Martins, Izabella Rodrigues; Bracht, Valter. Relações da Educação Física com o Programa Saúde Na Escola: visões dos Professores das escolas de Vitória/ES. Pensar a Prática, v. 18, n. 3, p. 1-13, 2015.

133. OMS (Organização Mundial da Saúde). Declaração de Alma-Ata. Conferência Internacional Sobre Cuidados Primários de Saúde. Alma-Ata, URSS, 6-12 de setembro de 1978. Disponível em: <http://www.opas.org.br/coletiva/uploadArq/Alma- Ata.pdf> Acesso em: 21 jun. 2016.

134. ONOFRE, Marcos Teixeira de Abreu Soares. Conhecimento prático, auto-eficácia e qualidade de ensino : um estudo multicaso em professores de educação física. Tese de Doutoramento. Universidade Técnica de Lisboa. Faculdade de motricidade Humana. 2000.

135. OPAS. Prevenção de doenças crônicas: um investimento vital. Brasília: Organização Mundial da Saúde, 2005.

136. Carta de Ottwa para la Promocion de la Salud: Primeira Conferência Internacional de Promoção da Saúde. 1986. Disponível em: $<$ http://www.paho.org/saludyescuelas/index.php?option=com_k2\&view=item\&id=191:health -promotion-ottawa-charter\&Itemid=337\&lang=es >. Acesso em: 25 nov. 2015.

137. PAIM, Jairnilson et al. Saúde no Brasil 1 O sistema de saúde brasileiro: história, avanços e desafios. Veja, v. 6736, n. 11, p. 60054-8, 2012.

138. PAIVA, Georgia Medeiros. Análise do Programa Saúde na Escola do município de fortaleza. 2012. $140 \mathrm{f}$. Dissertação (Mestrado) - Mestrado em Saúde Coletiva, Centro de Ciências da saúde, Fundação Edson Queiroz Universidade de Fortaleza, Fortaleza - Ceará, 2012.

139. PALMA, Alexandre de. Educação física, corpo e saúde: uma reflexão sobre outros "modos de olhar". Revista brasileira de Ciências do Esporte, v. 22, n. 2, 2001.

140. PEDROSO, Rosa Maria Correia Jerónimo; BRITO; Irma da Silva. Saúde dos estudantes do ensino superior de enfermagem: estudo de contexto na Escola Superior de Enfermagem de Coimbra. In R. Pedroso, \& I. Brito (orgs.) Série Monográfica Educação e Investigação em Saúde (pp.17-31). Coimbra: Unidade de Investigação em Ciências da Saúde: Enfermagem (UICISA: E) / Escola Superior de Enfermagem de Coimbra (ESEnfC). 
141. PENSO, Maria Aparecida et al. A relação entre saúde e escola: percepções dos profissionais que trabalham com adolescentes na atenção primária à saúde no Distrito Federal. Saúde e Sociedade. Saúde e Sociedade, v. 22, n. 2, p. 542-553, 2013.

142. PEREIRA, Liliane Machado et al. Programa Saúde na Escola: avaliação das condições de aptidão física dos estudantes da escola municipal José Maria Alkmin de Belo Horizonte. Fiep bulletin, v. 85, n. 1, p. 1-7, 2015.

143. PINTO, Hêider Aurélio et al. O Programa Mais Médicos e o fortalecimento da atenção básica. Divulg. saúde debate, n. 51, p. 105-120, 2014.

144. PORATH, Margareth et al. Fase de desinvestimento da carreira docente de professores de Educação Física. Movimento (ESEF/UFRGS), v. 17, n. 4, p. 203-222, 2011.

145. PRADO, Tereza Cristina Mendes; LIMA, Álvaro Pereira. Saúde Ocular: O Trabalho Preventivo do Enfermeiro no Programa de Saúde da Escola-PSE.Journal of Health Sciences, v. 15, n. 4, 2013.

146. QUEIROZ, Maria Veraci Oliveira et al. Cuidado ao adolescente na atenção primária: discurso dos profissionais sobre o enfoque da integralidade. Revista da Rede de

Enfermagem do Nordeste, v. 12, p. 1036-1044, 2011.

147. RAMIRES, Elyssia Karine Nunes Mendonça et al. Estado nutricional de crianças e adolescentes de um município do semiárido do Nordeste brasileiro. Revista Paulista de Pediatria, v. 32, n. 3, p. 200-207, 2014.

148. REIS, Inês Nascimento de Carvalho; SILVA, Ilda Lopes Rodrigues da; WONG-UN, Julio Alberto. Espaço público na Atenção Básica de Saúde: Educação Popular e promoção da saúde nos Centros de Saúde-Escola do Brasil. Interface-Comunicação, Saúde, Educação, v. $18,2014$.

149. REZENDE, Regiane. Escolas promotoras de saúde do Tocantins: "co-gestando" a rede. Prêmio Sergio Arouca de gestão participativa, 2007.

150. RIGO, Luis Carlos; RIBEIRO, Gabriela M.; HALLAL, Pedro C. Unidade na diversidade: desafios para a Educação Física no século XXI. Revista brasileira de Atividade Física \& Saúde, v. 16, n. 4, p. 339-345, 2012.

151. ROCHA, Dais Gonçalves et al. Processo de revisão da Política Nacional de Promoção da Saúde: múltiplos movimentos simultâneos. Ciência \& Saúde Coletiva, v. 19, n. 11, 2014.

152. ROCHA, Dais Gonçalves; MARCELO, Vânia Cristina; PEREIRA, Isabel M. T. Bicudo. Escola promotora da saúde: uma construção interdisciplinar e intersetorial. Revista Brasileira de Crescimento e Desenvolvimento Humano, São Paulo, v. 12, n. 1, p.57-63, 20 fev. 2002.

153. ROCHA, Dais Goncalves; TUSSET, Dalila. Relatório da I mostra programa saúde na escola e saúde e prevenção na escola do Distrito Federal, 2011. 
154. RONZANI, Telmo Mota; RODRIGUES, Marisa Cosenza. O psicólogo na atenção primária à saúde: contribuições, desafios e redirecionamentos. Psicologia ciência e profisssão, v. 26, n. 1, p. 132-143, 2006.

155. SA, Gisele Balbino Araujo Rodrigues de et al . O Programa Academia da Saúde como estratégia de promoção da saúde e modos de vida saudáveis: cenário nacional de implementação. Ciência \& saúde coletiva, Rio de Janeiro , v. 21, n. 6, p. 18491860, June 2016.

156. SANTIAGO, Lindelvania Matias de et al. Implantação do Programa Saúde na escola em Fortaleza-CE: atuação de equipe da Estratégia Saúde da Família. Revista brasileira de Enfermagem, v. 65, n. 6, p. 1-4, 2012.

157. SANTINI, Joarez; NETO, Vicente Molina. A síndrome do esgotamento profissional em professores de educação física: um estudo na rede municipal de ensino de Porto Alegre. Revista brasileira de Educação Física e Esporte, v. 19, n. 3, p. 209-222, 2005.

158. SANTOS, Kátia Ferreira dos; BÓGUS, Cláudia Maria. A percepção de educadores sobre a escola promotora de saúde: um estudo de caso. Revista brasileira de crescimento e desenvolvimento humano, v. 17, n. 3, p. 123-133, 2007.

159. SANTOS, Neudivania Paula dos; SANTOS, Maria Verônica da Silva; GOMES, Maria Amábia Viana. Implantação e Desenvolvimento do Programa Saúde na Escola (PSE) em uma Escola no Município de Marechal Deodoro, Alagoas. In: I Congresso de Inovação Pedagógica em Arapiraca, v. 1, n. 1 (1), 2015.

160. SANTOS, Raquel dos Anjos ; Mezzaroba, Cristiano. Programa Saúde na Escola e sua relação com a Educação Física: uma análise documental. Revista on line de Educação Física da UEG, v. 1, n. 4, p. 71-89, 2013.

161. SANTOS, Ana Luisa Batista et al. Educação física e o pet-saúde: uma estratégia complementar na formação para o SUS. Sanare-Revista de Políticas Públicas, v. 10, n. 2, p. 75-78, 2011.

162. SCHULER, Cristine. et al. Multiplicadores adolescentes do Programa Saúde na Escola : a prevenção entre pares. p. 38-43, 2015.

163. SÍCOLI, Juliana Lordello; NASCIMENTO, Paulo Roberto do. Promoção de saúde: concepções, princípios e operacionalização. Interface-Comunição, Saúde, Educação, v. 7, n. 12, p. 101-22, 2003.

164. SILVA JUNIOR, Aristides José da. Programa Saúde na Escola: limites e possibilidades intersetoriais. 2014. 160 f. Tese (Doutorado) - Programa de Pós-graduação em Educação, Instituto de Educação, Universidade Federal de Mato Grosso, Cuiabá-MT, 2014.

165. SILVA, Adna de Araújo. Avaliação da atuação do enfermeiro na prevenção de DST/AIDS no Programa Saúde na Escola. 2013. 107 f. Dissertação (Mestrado) - Programa de Pós-graduação em Enfermagem, Departamento de Enfermagem, Universidade Federal do Ceará, Fortaleza/CE, 2013. 
166. SILVA, Ana Carolina Feldenheimer da. Programa Saúde na Escola: análise da gestão local, ações de alimentação e nutrição e estado nutricional dos escolares brasileiros. 2014. 162 f. Tese (Doutorado) - Programa de Pós-graduação em Nutrição e Saúde Pública, Faculdade de Saúde Pública, Universidade de São Paulo, São Paulo, 2014.

167. SILVA, Ana Lúcia Alves Carneiro da. Promoção da Saúde na Escola: conhecimentos e práticas de profissionais da saúde e da educação. 2013. 107 f. Dissertação (Mestrado) Programa de Pós-graduação em Ensino na Saúde, Universidade Federal de Goiás, Goiânia, 2013.

168. SILVA, Andrea Rosane Sousa et al. Políticas públicas na promoção à saúde do adolescente escolar : concepção de gestores. Revista Enfermería Global, v. 14, n. 37, p. 268-285, 2015.

169. SILVA, Carlos dos Santos. O Fracasso do (a) Escola (r): questão de ótica. Rompendo o ciclo fechado de educação e saúde com a anamnese. Dissertação de mestrado. Universidade Federal Fluminense; 1991.

170. _. Promoção da saúde na escola: modelos teóricos e desafios da intersetorialidade no município do Rio de Janeiro. 2010. 220 f. Tese (Doutorado) - Curso de Saúde Pública, Escola Nacional de Saúde Pública Sergio Arouca, Rio de Janeiro, 2010.

171. SILVA, Carlos dos Santos; BODSTEIN, Regina Cele de Andrade. Referencial teórico sobre práticas intersetoriais em Promoção da Saúde na Escola. Ciência \& saúde coletiva, Rio de Janeiro , v. 21, n. 6, p. 1777-1788, jun. 2016.

172. SILVA, Kenia Lara et al. Promoção da Saúde no Programa Saúde na Escola e a inserção da enfermagem. Revista Mineira de Enfermagem, v. 18, n. 3, p. 623-629, 2014.

173. SILVA, Patrícia Ferrás Araújo da; BAPTISTA, Tatiana Wargas de Faria. Os sentidos e disputas na construção da Política Nacional de Promoção da Saúde. Physis: Revista de Saúde Coletiva, v. 24, n. 2, p. 441-465, 2014.

174. SILVA-ARIOLI, Inea Giovana et al. Promoção e Educação em saúde: uma análise epistemológica. Psicologia ciência e profissão, v. 33, n. 3, p. 672-687, 2013.

175. SILVEIRA, Catharina da Cunha. Escola e docência no Programa Saúde na Escola: uma análise cultural. 2014. 92 f. Dissertação (Mestrado) - Programa de Pósgraduação em Educação, Faculdade de Educação, Universidade Federal do Rio Grande do Sul, Porto Alegre, 2014.

SOARES, Carmen Lúcia et al. Metodologia do ensino de educação física: coletivo de autores. São Paulo: Cortez, 1992. (Coleção Magistério de $2^{\circ}$ grau. Série Formação do professor).

176. SOUZA, Nathália Paula de. Avaliação das ações de saúde e nutrição na perspectiva do Programa Saúde na Escola. 2012. 124 f. Dissertação (Mestrado) - Programa de Pósgraduação (mestrado em Nutrição), Departamento de Nutrição do Centro de Ciências da Saúde, Universidade Federal de Pernambuco, Recife, 2012. 
177. SPERÂNDIO, Ana Maria et al. 10 anos da Política Nacional de Promoção da Saúde: trajetórias e desafios. [Editorial]. Ciência \& saúde coletiva, v. 21, n. 6, p.1681-1682, jun. 2016. FapUNIFESP (SciELO). http://dx.doi.org/10.1590/1413-81232015216.10862016.

178. TABOSA, Hamilton Rodrigues et al. A gestão da informação no Programa Saúde na Escola em Fortaleza-ce : impasses e alternativas. Racin, v. 1, n. 1, p. 30-49, 2013.

179. TEIVE, Gladys Mary Ghizoni; Abud, Cristiane de Castro Ramos. O programa Saúde Escolar. Debates em Educação, v. 6, n. 12, p. 131-138, 2014.

180. TEIXEIRA, Carmen Fontes. Modelo de atenção à saúde: vigilância e saúde da família [online]. Salvador: Editora EDUFBA. Sala de aula series, nº3. ISBN 85-232-0400-8. Available from SciELO Books. http://books.scielo.org>. 2006. $237 \mathrm{p}$

181. TEIXEIRA, Mirna Barros et al. Avaliação das práticas de promoção da saúde: um olhar das equipes participantes do Programa de Melhoria do Acesso e Qualidade da Atenção Básica - PMAQ-AB. Saúde em Debate, v. 38, n. special, p. 52-68, 2014.

182. TELES, Liliane Alves da Luz. A nutrição no foco do Programa Saúde na Escola : reflexões sobre o processo de medicalização. Revista entreideias, v. 3, n. 1, p. 47-61, 2014.

183. TROST, Stewart. et al. Correlates of adult's participation in physical activity: review and update. Medicine and Science in Sports and Exercise, Filadélfia, v. 34, n. 12, p. 19962001, 2002.

184. TUSSET, Dalila et al. Análise das competências em promoção da saúde a partir do marco legal e dos discursos dos profissionais que implementam o Programa Saúde na Escola no Distrito Federal. Tempus Actas de Saúde Coletiva, v. 9, n. 1, p. 189-204, 2015.

185. TUSSET, Dalila. Competências em promoção da saúde no Programa Saúde na EscolaNO distrito federal. 2012. 161 f. Dissertação (Mestrado) - Programa de PósGraduação Stricto-Sensu em Educação Física, Faculdade de Educação Física, Universidade de Brasília, Brasília, 2012.

186. UCHÔA, Rita de Cássia Matos de Figueirêdo. O Programa Saúde na Escola sob o olhar dos gestores, educadores e participantes: um estudo no município de Manaus. 2012. 60 f. Dissertação (Mestrado) - Programa de Pós-graduação Mestrado em Ciências da Saúde, Universidade Federal do Amazonas, Manaus, AM, 2012.

187. VIEIRA, Maria Edna Moura. Programa Saúde na Escola: a intersetorialidade em movimento. 2013. 121 f. Dissertação (Mestrado) - Programa de Pós-graduação em Processos de Desenvolvimento Humano e Saúde, Instituto de Psicologia, Universidade de Brasília, Brasília-DF, 2013.

188. VILARTA, Roberto (Org.). Qualidade de Vida e Políticas Públicas: Saúde, lazer e atividade física. Campinas: Ipes Editorial, 2004. 154 p. Disponível em: Acesso em: 18 dez. 2014. 
189. WESTPHAL, Márcia Faria. O Movimento Cidades/Municípios Saudáveis: um compromisso com a qualidade de vida. Ciência \& saúde coletiva, Rio de Janeiro, v. 5, n. 1, p. 39-51, 2000

190. WESTPHAL, Márcia Faria. Tratado de saúde coletiva. In: CAMPOS, Gastão Wagner de Sousa; MINAYO, Maria Cecília de Souza; AKERMAN, Marco; DRUMOND JÚNIOR, Marcos. CARVALHO, Yara Maria de Carvalho. (org.). Tratado de saúde coletiva. São Paulo: Editora: Hucitec, 2013, 968 p.

191. WESTPHAL, Marcia Faria; MENDES, Rosilda. Cidade saudável: uma experiência de interdisciplinaridade e intersetorialidade. Revista de Administração Pública, v. 34, n. 6, p. 47-61, 2000.

192. WIMMER, Gert Ferreira; GO, Figueiredo. Ação coletiva para qualidade de vida: autonomia, transdisciplinaridade e intersetorialidade Ciência \& saúde coletiva, v. 11, n. 1, p. 145-154, 2006.

193. WOSNY, Antonio de Miranda, MONTICELLI, Marisa. Promoção à saúde: trajetória histórica de suas concepções. Texto Contexto Enfermagem, v. 15, n. 2, p. 352-8, 2006. 


\section{APÊNDICE A \\ TERMO DE CONSENTIMENTO LIVRE E ESCLARECIDO}

Prezado(a), convidamos você a participar de uma pesquisa sobre o tema: "SAÚDE NA ESCOLA". É uma pesquisa de mestrado desenvolvida por Iraneide Etelvina Lopes, aluna do Programa de Pós-Graduação da Faculdade de Educação Física da Universidade de Brasília sob orientação da Professora Doutora Júlia Aparecida Devidé Nogueira.

Essa pesquisa foi aprovada pelo Comitê de Ética em Pesquisa da Faculdade de Ciências da Saúde da Universidade de Brasília (FS/UnB nº. 44493215.0.0000.0030) e tem como objetivo conhecer a percepção dos profissionais que atuam nas escolas do Distrito Federal sobre Promoção da Saúde e o Programa Saúde na Escola.

Sua participação é voluntária, porém fundamental para nos ajudar a compreender os fenômenos da promoção da saúde no ambiente escolar. Caso aceite, deverá participar de uma entrevista com duração estimada de 10 minutos, além de assinar esse Termo de Consentimento Livre e Esclarecido.

A entrevista será gravada e utilizada exclusivamente para as análises desta pesquisa científica. Os arquivos de áudio ficarão sob a guarda da pesquisadora por um período de cinco anos, após isso serão destruídos. Lhe asseguramos que todas as informações serão divulgadas de forma anônima e respeitarão os preceitos éticos. Mesmo assim, caso não se sinta confortável em responder alguma das questões ou queira se retirar da pesquisa a qualquer momento, não haverá nenhum prejuízo para você. Os resultados da pesquisa serão publicados em periódicos científicos e apresentados à todos os participantes.

Caso haja qualquer dúvida coloco-me à disposição para esclarecimentos. Se preferirem poderão contatar a pesquisadora Iraneide Etelvina Lopes no telefone (61) 8203-7939 ou email: iraneide12@gmail.com; a orientadora Júlia Aparecida Devidé Nogueira no telefone (61) 8112-7346 ou e-mail: julianogueira @unb.br; ou o Comitê de ética e pesquisa no telefone (61) 3107-1947 ou e-mail cepfs@unb.br.

Agradecemos a atenção e contamos com a sua colaboração.

Brasília, de outubro de 2015. 


\section{APÊNDICE B}

\section{ROTEIRO DE ENTREVISTA PROFESSOR DE EDUCAÇÃO FÍSICA}

1. Você pode se apresentar falando seu nome e contando um pouco sobre sua FORMAÇÃO profissional?

\subsection{Curso superior. EM QUÊ??}

1.2. Formação continuada. QUAL ÁREA?

2. Me fale um pouco sobre suas atribuições no cotidiano na escola.

\section{$\underline{\text { Aparece o PSE } \rightarrow}$}

2.1. Me fale um pouco sobre seu envolvimento com o Programa.

\section{Não Aparece o PSE $\rightarrow$}

2.1. Você conhece o Programa Saúde na Escola?

\section{$\underline{\mathrm{SIM}} \rightarrow$}

2.1.1. Qual sua percepção sobre o Programa?

$\underline{\text { NÃO } \rightarrow}$ Explicar brevemente o programa e informar que há um eixo de ações de práticas corporais e atividades físicas no PSE.

O programa saúde na escola é uma politica pública do Governo Federal onde as escolas em parceria com a unidade de saúde, fazem uma adesão do programa. Nessa adesão devem ser cumpridas uma série de ações por parte da unidade de saúde e da escola por meio do planejamento do Projeto Político Pedagógico da escola. Entre as ações se destacam atividades de promoção da saúde e prevenção de doenças. O PSE é composto por vários eixos de ação entre eles tem o eixo de práticas corporais e atividades físicas na qual há uma aproximação com a disciplina de Educação Física.

3. Você sabia que o programa inclui em suas ações as práticas corporais e atividades físicas?

\section{$\underline{\mathrm{SIM} \rightarrow}$}

3.1. Qual sua percepção (avaliação) sobre a inclusão das práticas corporais e atividades físicas no PSE?

\section{$\underline{\text { NÃO } \rightarrow}$}

3.1. Você considera as ações de práticas corporais e atividades físicas importantes? Por quê?

4. Como você vê a relação das práticas corporais e atividades físicas com a promoção da saúde?

\subsection{O que é promoção da saúde para você? POR EXEMPLO?}

5. No percurso de sua formação profissional você teve contato com o tema da promoção da saúde?

5.1. Onde? Quando? Como?

Na graduação (licenciatura) você teve aulas relacionadas à promoção da saúde?

6. E para finalizar, você já teve oportunidade de atuar em algum programa ou atividades relacionados à promoção da saúde? Quais?

Encerramento: Agradecer pela participação e informar sobre o retorno da informação. 


\section{LISTA DE ANEXOS}

\section{ANEXO I}

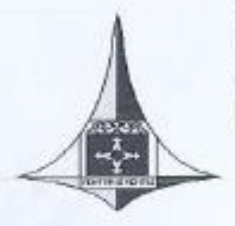

GQVERNO DO DISTRITO FEDERAL

Secretaria de Estado de Educação

Subsecretaria de Infracstrutura e Apoio Educacional

Coordenaçăo de Saúde e Assistência ao Estudante

Termo de concordância de Instituição Coparticipante na realização de pesquisa científica

Brasília, 14 de abril de 2015.

Da: Coordenação de Saúde e Assistência ao Estudante da Secretaria de Estado de Educaçăo.

Ao: Comitê de Ética em Pesquisa com Seres Humanos da Faculdade de Saúde da Universidade de Brasilia.

Referêneia: Pesquisa com profissionais do Programa Saúde na Escola do Distrito Federal

Declaro que a Coordenação de Saúde e Assistência ao Estudante da Secretaria de Estado de Educação do Distrito Federal apoia e é coparticipante da pesquisa "PRATTCAS CORPORAIS/ATIVIDADES FÍSICAS COMO EIXO DE AÇÃO NO PROGRAMA SAÚDE NA ESCOLA NO DISTRITO FEDERAL" - realizada por Iraneide Etelvina Lopes, aluna do Programa de Pós Graduação em Educação Física da Universidade de Brasília e orientada pela Dra. Júlia Aparecida Devidé Nogueira, Professora da Faculdade de Educação Física da mesma instituição.

A primeira etapa do estudo é exploratória, onde a obtençāo das informaçóes ocorrerá mediante contato direto da pesquisadora com o Programa Saúde na Escola dentro de sua realidade social, o Distrito Federal. A seguir serāo realizadas entrevistas com profissionais que atuam no Programa Saúde na Escola. Os profissionais serão convidados e decidirão participar de forma livre e esclarecida; as entrevistas serão realizadas com a utilização de roteiro semiestruturado e serão gravadas, transcritas, analisadas e divulgadas de acordo com os princípios éticos da pesquisa qualitativa em saúde, inclusive os contidos na resoluçāo 466/2012 do Conselho Nacional de Saúde. A coleta de informaçốes ocorrerá entre abril e setembro de 2015.

Declaro que estou de acordo com a condução da pesquisa nas premissas em que o programa ocorre; e que estou ciente de nossas corresponsabilidades como instituição coparticipante no cumprimento da Resolução 466/2012 do Conselho Nacional de Saúde.

Declaro que estou de acordo com a conduçāo da pesquisa nas premissas em que o programa ocorre; e que estou ciente de nossas corresponsabilidades como instituição coparticipante no cumprimento da Resolução 466/2012 do Conselho Nacional de Saúde.

Sendo verdade o que se apresenta, firmo abaixo:

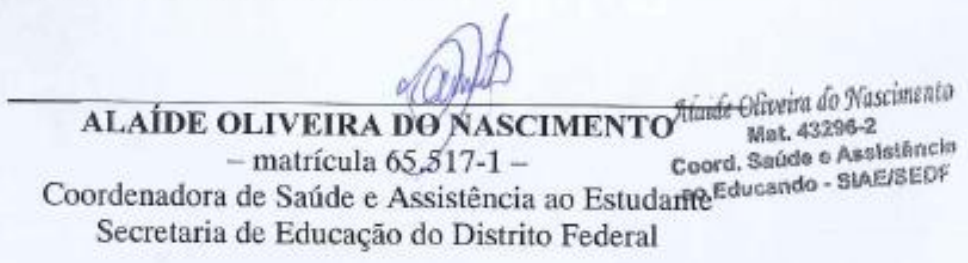

Secretaria de Estado de Educacio Subsecretaria de Infraestrutura e Apoio Educacional Coordenaçio de Sáde e Asisténcia ao Educando SGAN 607, Projech̆o D, Sala 112 CEP- 70.850-070 Telefones: $3901-2280$ e $3901-2411$ 


\begin{abstract}
ANEXO II
Brasilia, 13 de abril de 2015.

\section{Termo de concordância de Instituição Coparticipante na realização de pesquisa científica}

Da: Secretaria Estadual de Saúde do Distrito Federal

Ao: Comitê de Ética em Pesquisa com Seres Humanos da Faculdade de Saúde da Universidade de Brasília

Ref.: Pesquisa com profissionais do Programa Saúde na Escola do Distrito Federal

Declaro que a Secretaria Estadual de Saúde apóia e é instituição coparticipante da pesquisa "PRATICAS CORPORAIS/ATIVIDADES FÍSICAS COMO ELXO DE AÇÃO NO PROGRAMA SAÚDE NA ESCOLA NO DISTRITO FEDERAL" - realizada por Iraneide Etelvina Lopes, aluna do Programa de Pós Graduação em Educação Física da Universidade de Brasília e orientada pela Dra. Júlia Aparecida Devidé Nogueira, Professora da Faculdade de Educação Física da mesma instituição.

A primeira etapa do estudo é exploratória, onde a obtenção das informações ocorrerá mediante contato direto da pesquisadora com o programa dentro de sua realidade social, o Distrito Federal. A seguir serão realizadas entrevistas com profissionais que atuam no Programa Saúde na Escola. Os profissionais serão convidados e decidirão participar de forma livre e esclarecida; as entrevistas ocorrerão utilizando um roteiro semi-estruturado e serão gravadas, transcritas, analisadas e divulgadas de acordo com os princípios éticos da pesquisa qualitativa em saúde, inclusive os contidos na resolução 466/2012 do Conselho Nacional de Saúde. A coleta de informações ocorrerá entre abril a setembro de 2015.

Declaro que estou de acordo com a condução da pesquisa nas premissas em que o programa ocorre; e que estamos cientes de nossas corresponsabilidades como instituição coparticipante no cumprimento da Resolução 466/2012 do Conselho Nacional de Saúde.

Sendo verdade o que se apresenta, firmamos abaixo:

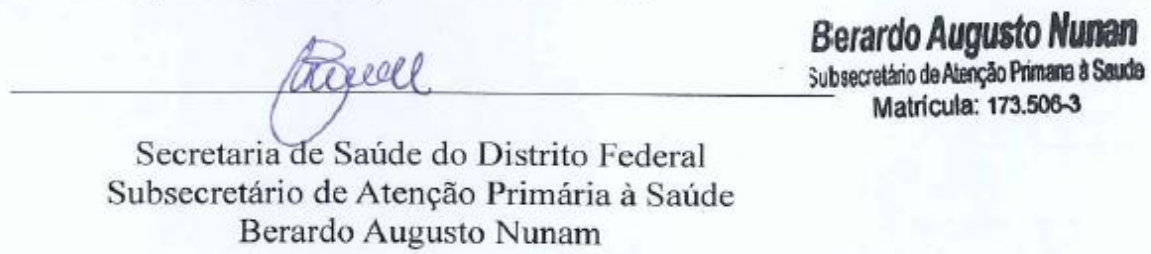




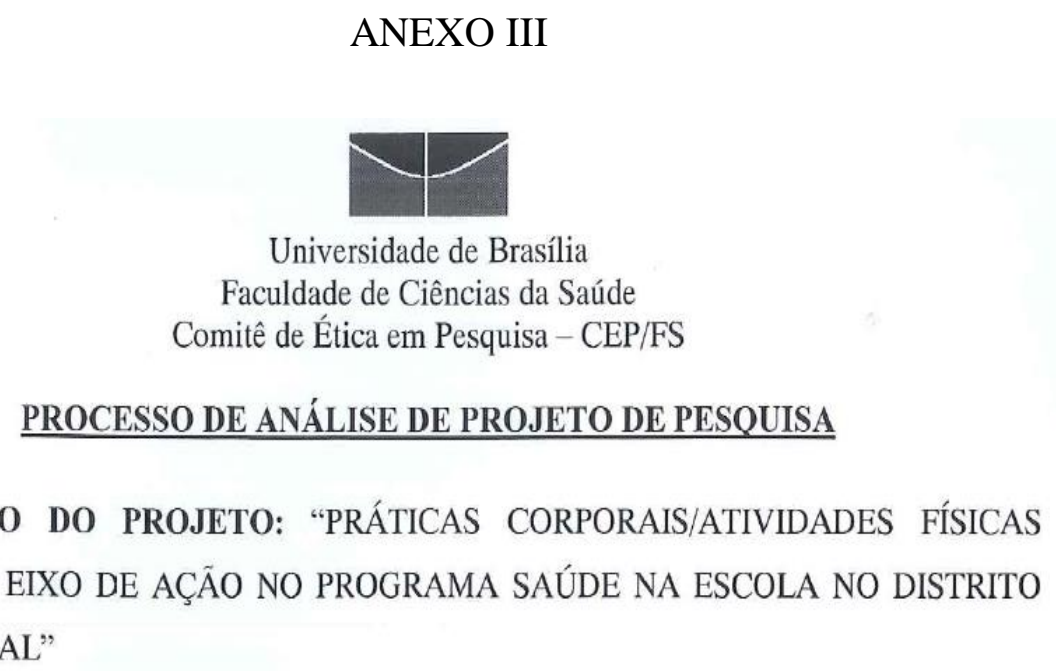

TÍTULO DO PROJETO: "PRÁTCAS CORPORAIS/ATIVIDADES FISICAS COMO EIXO DE AÇÃO NO PROGRAMA SAÚDE NA ESCOLA NO DISTRITO FEDERAL"

PESQUISADORA RESPONSÁVEL: IRANEIDE ETELVINA LOPES

DATA DE ENTRADA: 02/08/2015

CAAE: 44493215.0 .0000 .0030

Com base na Resolução 466/12, do CNS/MS, que regulamenta a ética em pesquisa com seres humanos, o Comitê de Ética em Pesquisa com Seres Humanos da Faculdade de Ciências da Saúde da Universidade de Brasília, após análise dos aspectos éticos e do contexto técnica-científico, resolveu APROVAR o projeto intitulado PRÁTICAS CORPORAIS/ATIVIDADES FÍSICAS COMO EIXO DE AÇÃO NO PROGRAMA SAÚDE NA ESCOLA NO DISTRITO FEDERAL" Parecer nº 1.168.651, em 8 de julho de 2015 .

Notifica-se o(a) pesquisador(a) responsável da obrigatoriedade da apresentação de um relatório semestral e relatório final sobre o desenvolvimento do projeto, no prazo de 1 (um) ano a contar da data de aprovação.

Brasília, 1 de setembro de 2015.

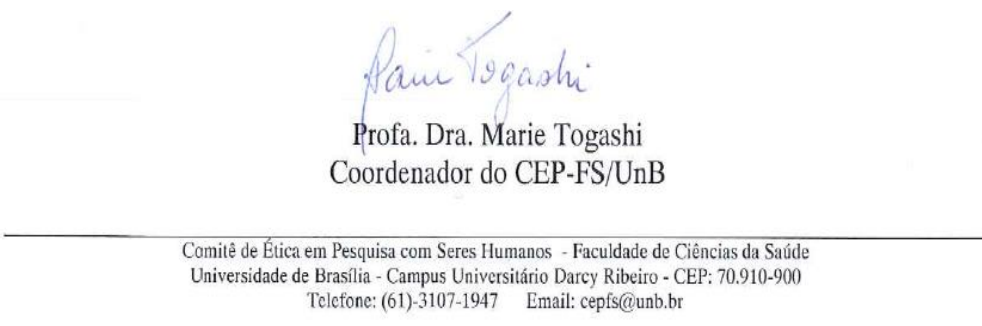

